

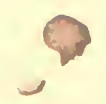

\section{Southern Branch}

$$
\text { of the }
$$

University of California

\section{Los Angeles}

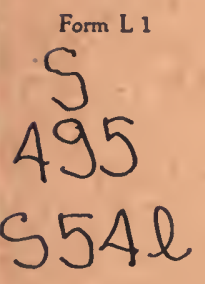


This book is DUE on the last date stamped below MAR 1 APP 2932 1933 APR 201950 JAN 301935

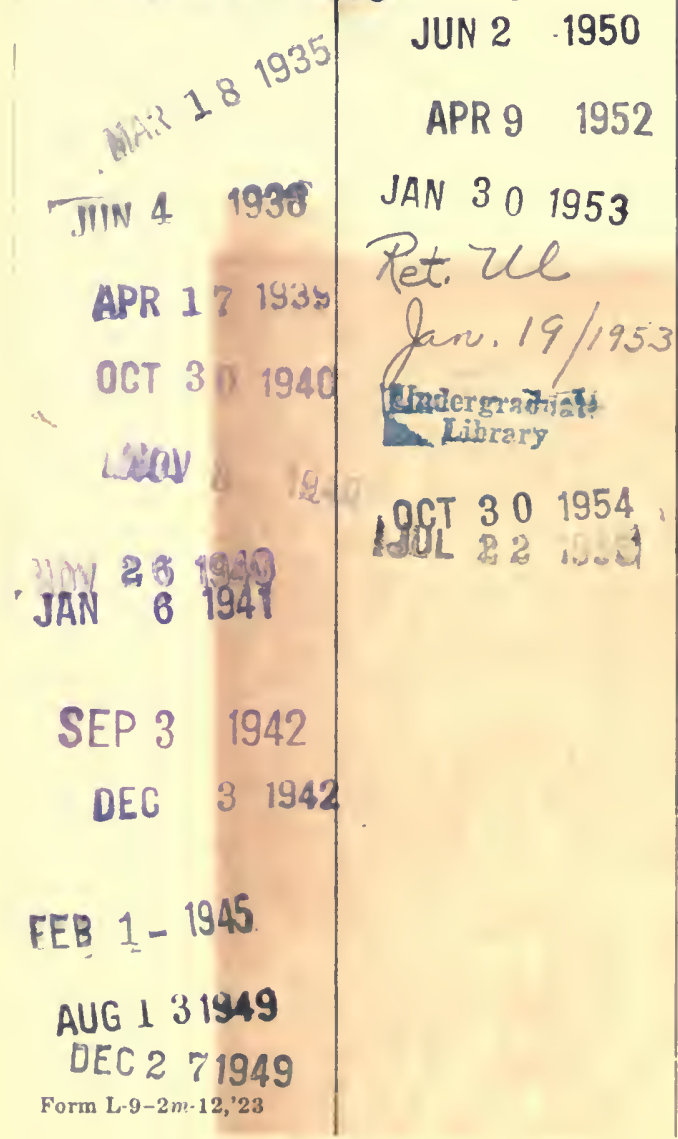


Digitized by the Internet Archive in 2007 with funding from Microsoft Corporation 



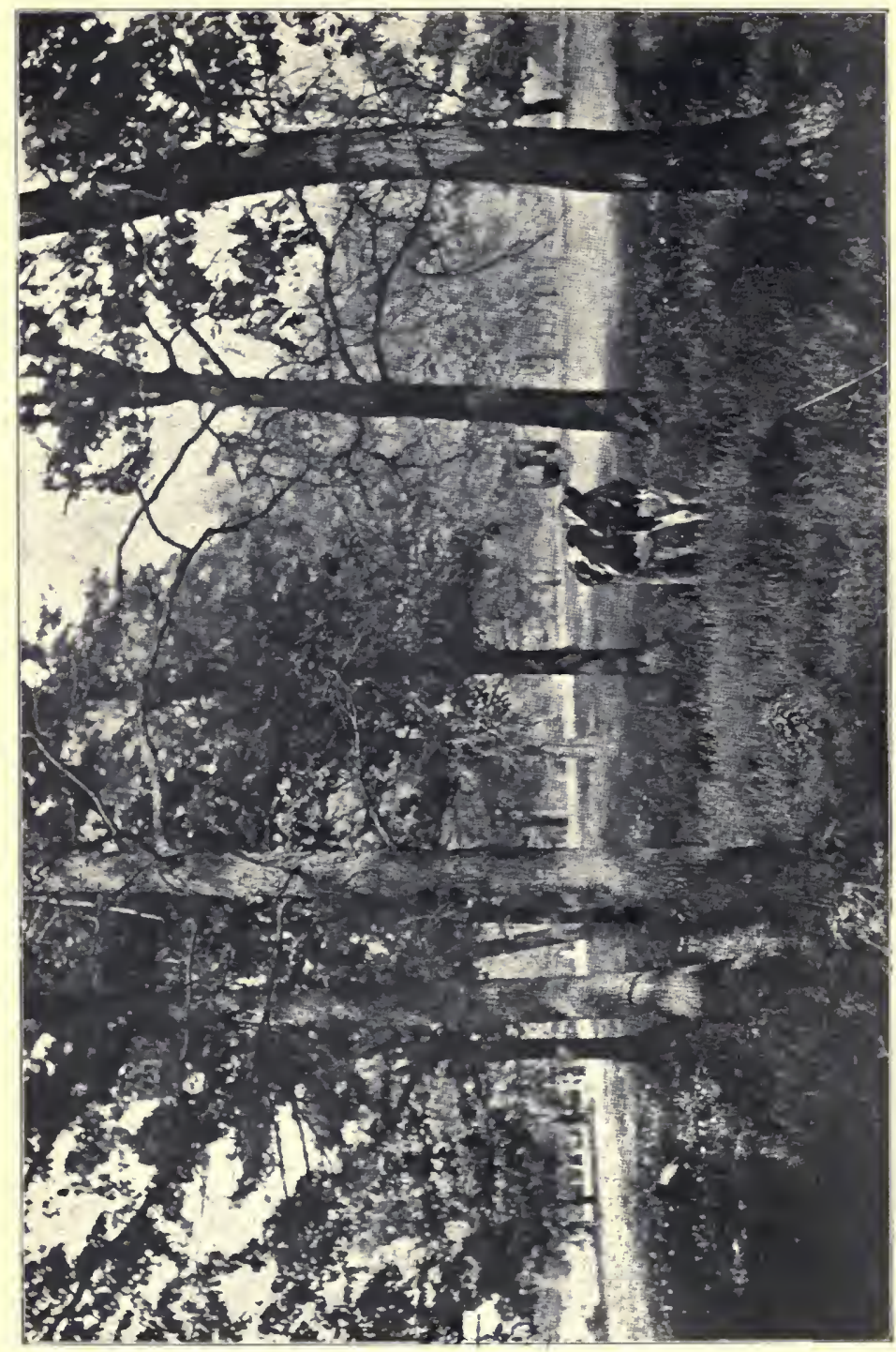




\title{
LIFE ON THE FARM
}

0R, SCIENTIFIC AGRICULTURE SIMPLIFIED

\author{
A READING BOOK \\ FOR GRAMMAR AND HIGH SCHOOLS
}

BY

H I R A M H. SHEPARD

Science Instructor in the Chicago Normal School

15400

ILLUSTRATED

CHICAGO

A. FLANAGAN CO.

15460 
COPYRIGHT, $190 \mathrm{I}$

BY A. FI.ANAGAN CO 


\section{5 \\ $5.54 l$}

\section{PREFACE.}

Life on the farm now is not what it used to be. 'The general development of the age accounts for this. Each year adds something new to the agricultural field, and not infrequently are these new things so complex in their nature that the broadest scientific knowledge is required for their interpretation and use. There is probably no other industry in which so many branches of science enter as farming; nearly the whole list can be used in some way or other.

This volume is designed, primarily, as a reader, or text-book; in rural schools of agricultural regions; but we think it could be used with profit in $\checkmark$ both village and city schools. Pupils can learn to read by reading about real things which are in close touch with their daily lives, and which they es wish to remember, as well by reading about remote, fictitious things which they can not and do not care to remember. First-hand knowledge should be learned before any other. The things to be studied on a farm are full of interest, beauty, and utility. Where is a field more varied and vital than the one 
which includes soil, air, light, heat, plants, germs, insects, birds, and domestic animals?

Our aim has been to treat the subjects scientifically, but with as few needless technicalities as possible.

Acknowledgment is due to Prof. Lewis W. Colwell, principal of the Linné Grammar School, Chicago, Illinois, for his suggestions in the first reading of the manuscript; to Prof. Alden S. Rinker, for the use of three photographs; and to Mr. C. W. Mogg, for the use of three photographs. Much help has also been derived from the farmers in and around Linn, Illinois, with whom we spend two or three months each summer. They have been untiring in their efforts to explain and demonstrate practical farm work. Especial gratitude is due to $\mathrm{Mr}$. William F. Corrie, a boy companion in farm life and work, and who still is ever ready to explain how wealth can be secured from wornout land, and how a successful, happy life can be found on a farm.

If this volume helps, only in a small way, to explain some of the general principles of agriculture, to lend an interest to the appreciation and the enjoyment of nature, and to elevate the dignity and nobility of farm life, we shall feel well repaid for the labor of its preparation.

\section{Hiram H. Shepard.}

Chicago Normal School,

October, I90I. 


\section{TABLE OF CONTENTS.}

PAGE

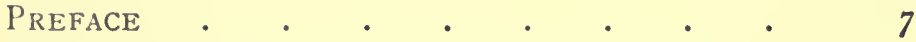

\section{CHAPTER I-THE SOIL.}

How Soll is Formed .

Water Transports Soll . . . . . . I2-I3

Effects of Soil Erosion on the Surface of THE EARTH . . . . . . I4-18 Surface Texsion, Evaporatio, Gravity . . i9-20 How Water in the Soll Feeds Plants • . $21-22$ When and How Plowing Benefits Soll. . . 23 The Use of Soll Air . . . . . . . 26 Why Cultivation Benefits Crops . . . 27 Sources and Uses of Soll Heat . . . $\quad 29$ Chemical Composition and Kinds of Soll $\quad$ • 34 Work of Crayfish, Axts, Rodents, AxgleWORMS, ETC.

\section{CHAPTER II-PLANTS.}

Soll the Ideal Home for Plants 42 How Plants are Distributed over the Earth 43-44 The Struggle of Plants for Existexce . Simple and Complex Plants . . . . . 47 Organs and Functions of Plants . . . 5 I Why Plants Have so Many Roots and Leaves 53 Some Interesting Facts about Leaves • • 55-59 
Where Leaves Get Their Material.

Arrangement, Number, and Forms of Leaves What Plants do with Their Food

\section{CHAPTER III-TREES.}

The Study of Trees of Great Importance . 85 How Trees Benefit Life . . . • . 87 Planting and Cultivatixg Groves . . • . 88 Trees Afford Beauty and Shelter Birds 89 Characteristics axd Uses of Ixdividual Trees 92-I03 (Elm, Maple, Oak, Cottonwood, Poplar, Hickory)

\section{CHAPTER IV-INSECTS.}

The Four Periods ix Ixsect Life . $\begin{array}{r}104 \\ .105-107\end{array}$ What Ixsects Eat Duriag These Stages . Ixtelligexce Displayed by Ixsects ix SecurING FOOD, ETC.

How Insects Aid in Plant Life Ixsect Exemies . Means for Destroying Insects Some Common Ixsect Pests Life-History OF THE House FLy - IO8- 1 I 5 Weevils, How and Where They Work Graxary Weevil, Graix Moth, Indian Meal

\section{Moth}

Operations of the Hessian Fly IOg-I I 2 I 2 I I I 7 Bugs in General, the Squash Bug How to KeEP Out Ixsects 


\section{CHAPTER V-BIRDS.}

Purposes of Birds in the Cycle of Life. . I30

What Birds Feed upon . . . . • . I3I

Relation of the Food of Birds to Farming

ANd Gardening . . . . . . . . 134

Why Birds Should be Protected • . I34 I36-I39

Pleasure from the Beauty and the Cheerful

SONgs OF BIRDS . . . . . . . . 138

Individual Birds-The Useful IVoodpecker • 139

Why the Sivallow Should be Protected . I4I-I 43

The Meadow LARK, Its Food, Its Cheerful

SONG . . . . . . . . . . . 144

Unwise Destruction of Quails axd Sparrows

The Owl, the House Wrex, Robins Blue-

BIRDS, BOBOLINKS • • . . I33, I48, I50

\section{CHAPTER VI-BACTERIA.}

What Bacteria Are.

The Thré Classes-Useful, Harmful,

NeIther USEFUl NOR HARMFUL . . . I I I

Sirapes of Bacteria, How They Grow . . I 52

Conditions of Life and Active Existexce . $\quad$ I 54

How Bacteria Preserve Life and Make Solls

FERTILE.

Why Heat ANd MoIsture Injure Graix AND

$\mathrm{HAY}$

Causes of Decay ix Fruits, Vegetables axd

MeATS .

How Food may ib Preserted . . . . . i6o

Sources of Milk Contamination . . . I6I

Bacteria Brexeficial iN Butter and Cheese-

MAKING . . . . . . . . I64

How Bacteria Change Cider to Vinegar • 165 


\section{LIST OF ILLUSTRATIONS.}

A Beautiful Farm Scene . . . . . . Frontispiece

Soil-Building in the Forest . . . . . . . . Io

Soil-Building in the Swamp . . . . . . . . $\quad$ I2

Soil-Wearing Along the Roadside . . . . . . I5

Soil-Wearing Along the Bronk . . . . . . . 17

Where the Soil is Well Cultivated . . . . . . 30

Red Clover, Timothy, Oats and Wheat . . . . . 45

An Autumn Corn Field . . . . . . . . . 46

Hay Cutting and Stacking . . . . . . . 48

Hay Stacks . . . . . . . . . . . 5 I

In the Wheat Field . . . . . . . . . 57

Leaves and Blossoms . $\quad . \quad$. . . . . . 64

Threshing Wheat $. \quad . \quad . \quad . \quad . \quad . \quad 067$

Measuring Wheat at the Thrasher . . . . . . 7 I

Corn Growing • • • • • • • . 74

Cutting Corn with a Machine . . . . . . 76

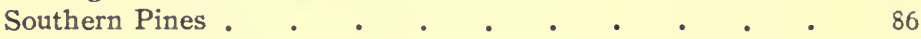

Cottonwood Tree . . . . . . . . . . 90

The Elm and the Box Elder . . . . . . . 93

Cabbage Butterfly, Caterpillar and Chrysalis . . . . 105

Cecropia Moth . . . . . . . . . . 107

How Insects Carry Pollen . . . . . . . . III

The Dragon Fly . $\quad$ • . . . . . . $\mathrm{II}_{4}$

Woolly Aphis of the Apple . . . . . . . . I2

Squashvine Borer . . . . . . . . . 127

The Kingfisher . . . . . . . . . . 130

The Woodpecker . . . . . . . . . ${ }_{132}$

The Screech Owl . . . . . . . . . . 135

The Bobolink . . . . . . . . . . 137

The Swallow . . . . . . . . . . . I4I

The Bluebird . . . . . . . . . $~ I 44$

The Robin . . . . . . . . . . . I49

Bacteria . . . . . . . . . . . ${ }_{152}$ 


\section{LIFE ON THE FARM.}

CHAPTER I.

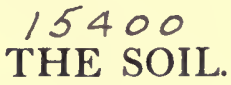

How soil is formed. Relation of water to soil. Water both destructive and useful. Movement of water in the soil. Where the water goes. Retention of soil water. When plowing benefits soil. Soil air. Why cultivation is beneficial. Effect of air pressure. Soil temperature. Relation of heat to soil. Chemical composition and kinds of soil. Elements composing the suil. Relation of earthworms and other small animals to soil fertility.

The soil is the source from which many useful things come. Wheat, from which bread is made, comes directly from the soil; and most of the meat we eat was once in the form of grain or hay, and this grows directly from the soil. The same may be said of the different kinds of cloth, leather, carpets, lumber, and a host of other useful things.

Soil is composed of decayed rocks, and of the remains of plants and animals. It has been forming for thousands of years, and the same work is going on to-day.

Roots of plants, from the tiny weed that grows by the roadside to the forest tree, have the power of penetrating the earth in such a way as to break 
up the rocks and make them fit food for plants. This is done in several ways. Growing roots have great power of expansion, so much so that when they enter the cracks of rocks, or grow between rock layers, they crowd these segments apart and

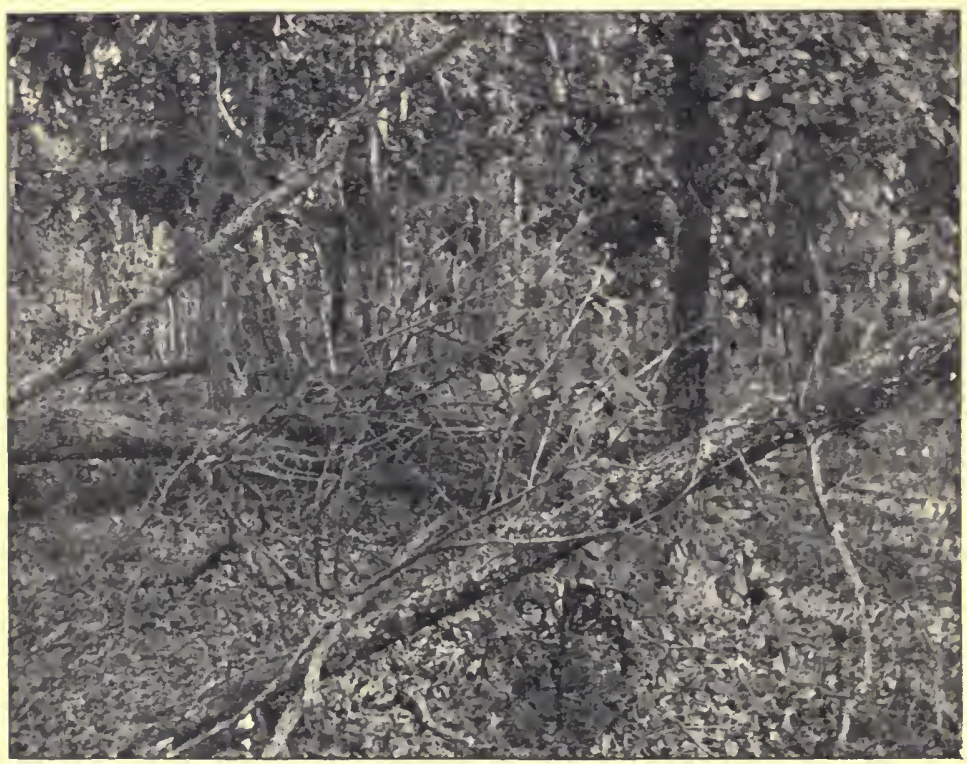

SOIL-BEILDING IN THE FOREST.

break the rocks to pieces. Then again, the roots of plants have little glands in them. These send out acids which have the power of dissolving rocks and small pieces of earth. In this way plants are enabled to take earthy material into the structure of their 
bodies as food. When they die and decay, this is left as food for other plants. The gray ash left after plants are burned, is the earthy matter.

As with most things in nature, there is a constant and ceaséless change of activity in the process of soil-building. Plant food, stored in the soil during one season, is partly washed away by rains, partly taken up by plants, and partly left over for future years. This work goes on year in and year out, and must continue to do so as long as we exist upon the earth, for it is the great storehouse from which alone food for plants and animals may be drawn.

\section{RELATION OF WATER TO SOIL.}

Scattered through the air in all places, and at all times, are countless numbers of very fine dust particles. They are so small that they cannot be seen with the naked eye, yet their presence in the air is probably one of the causes of the blueness of the sky. Every gust of wind catches them up and bears them away high over our heads and over the tops of trees and mountains. The heavier particles fall again when the air becomes still, but the finer and lighter ones float in the air a very long time. This is true not only of 'fine bits of wood, paper, and such light material, but of rocks, and the heavy metals. When anything is powdered fine enough, each particle has so much surface exposed to the air, compared with its volume, that it will float as lightly as a feather. 
Men who have made a careful study of rain say that these fine dust particles in the air have the power of attracting water vapor. When these little dust particles have gathered a thick film of water around themselves, they become so heavy that they can no longer float, and so fall to the earth as

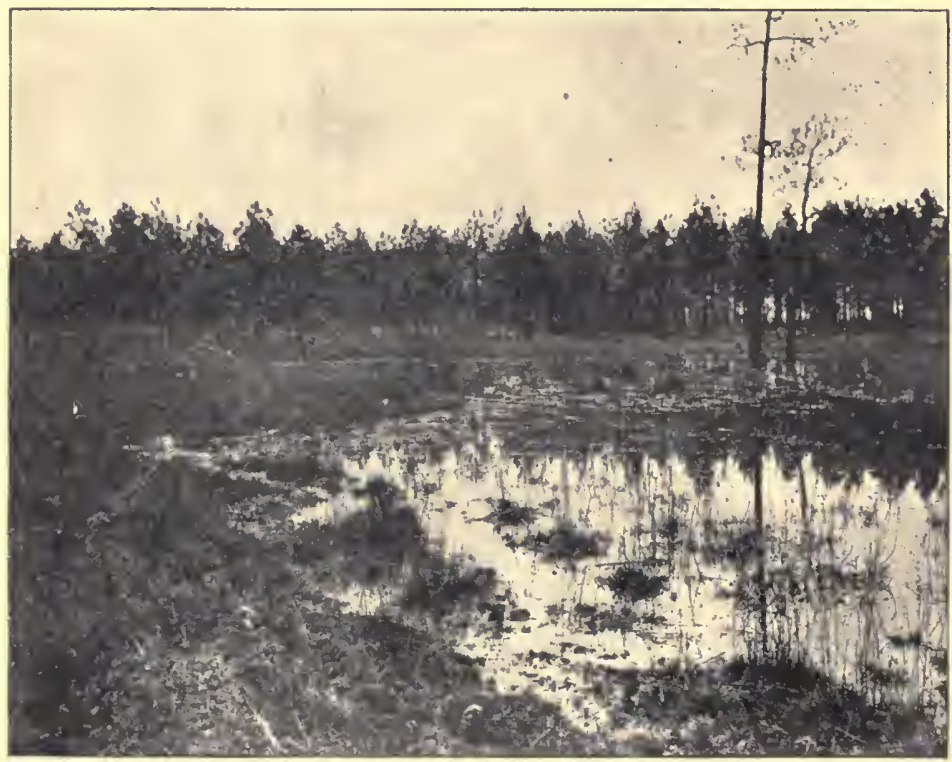

SOIL-BUILDING IN THE SWAMP.

drops of rain. They grow larger and larger as they fall, till, on striking the ground, the surface of a pond, or the leaves of plants, they are no longer fine particles of mist, but drops of water large enough to be seen and felt. 
Rain, in falling, not only carries down with it these particles of dust around which it clings, but acids, which help to dissolve the rocks. Rock thus dissolved is caught in the soil to remain as plant food; or is borne away into streams, and thence to the sea. Here some of it is taken up by such animals as oysters and corals. They are thus enabled to secrete the hard outer skeletons of their bodies. Some of it finds its way down through the earth to the permanent water layers, or veins, from whence we get it as the hard water of wells and springs.

Carbonic acid is brought down by every rain. It is constantly poured into the air from the chimneys of houses and factories, from the lungs of animals, and from decomposing vegetation. It has the power, when mixed with water, of dissolving limestone. Many caves in Kentucky and Indiana have been formed by this action. Water bearing this acid in solution has trickled down into the crevices of the limestone deposits of those regions and gradually eaten out cavities so large that people can walk into some of them for miles.

Rain, then, not only falls upon the earth to make it productive, but it also washes the air clean of its impurities, making it wholesome and pure for us to breathe. The atmosphere of cities has more impurities in it than that of the country. For this reason the free, open country is a more healthful place for dwelling. 
WATER BOTH DESTRUCTIVE AND USEFUL.

Water is destructive as well as useful. Evidence of this can be seen after every heavy rain in the amount of earth washed down from the steep, unprotected hillsides. Similar action takes place on the more level ground, especially when it is not protected by plant growth, and even then some is washed away. Some of the soil washed away by the water is carried only a few feet, and settles down of its own weight if the water flows slowly or spreads out into shallow pools. Some is carried many rods, sometimes settling down and spreading out in a thin layer over a large piece of low land. The finest soil is carried into the rivers and finally reaches the sea. More than a hundred million tons are thus carried annually by the Mississippi to the Gulf of Mexico.

There is a difference between water wearing land away and dissolving it away. Soil worn away makes water muddy, but the water may hold, in addition, dissolved matter which is not seen. Muddy water soon becomes clear when not in motion; but after it becomes perfectly clear, it nearly always contains other earthy matter which will not settle, regardless of the length of time that it remains quiet. This dissolved matter, however, can be obtained by evaporating the water.

The washing away of soil by the action of water 
can scarcely be overestimated. One can see the effects of it by the roadside, beside the small rivulets and streams, in the garden and yard, and in the fields. It is the force that cuts down the hills and spreads them out into level plains.

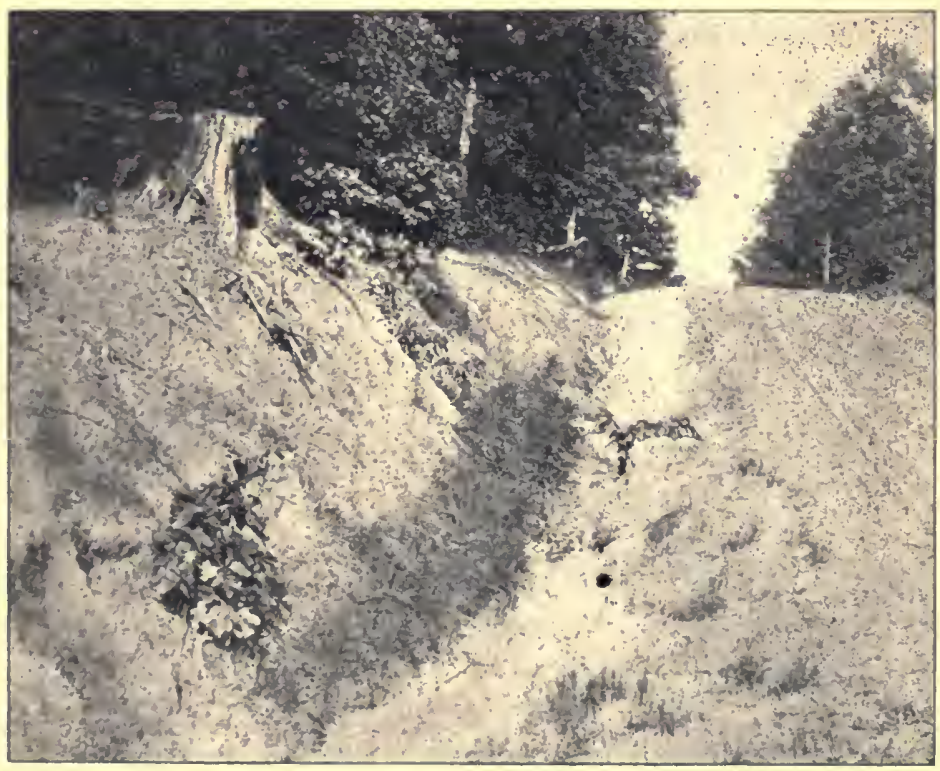

SOIL-WFARING ALONG THE ROADSIDE.

It takes hold of everything it can grasp and carries it from one place to another. A strip of plowed soil several inches deep may be washed by a heary rain to a lower level on the opposite side of a wide field, or even into an 
adjoining field. There is not so much loss, though, if nothing more disturbs it; but when nothing hinders, and the swiftly-flowing torrent carries it into the rivers, and thence to the sea, then the loss, so far as the present is concerned, is complete. Those having hilly or rolling land should cultivate it so as to prevent washing away as much as possible.

Stems, roots, branches, and leaves of plants,especially the roots,--help to hold the soil against the erosive action of water. Grass is especially good on ordinary ground, and trees for steep hills. All hills that wash away so much that they become barren in most places, should be planted with trees so as to stop the wearing. The trees would also be a great benefit in many other ways besides their value as timber (which would result after a number of years). Soil which unavoidably washes from cultivated fields can be caught and held on the lower ground by keeping the lower ground planted in grass of some kind. This not only tends to level up the hilly fields, but the soil thus made is of the best quality, being deep, rich, and in many cases almost inexhaustible. The writer has just visited a large field which is covered with a layer of soil, averaging about two feet in depth, washed down from the higher land above it. The crops of wheat, oats, clover, and corn now growing on it surpass those of any of the adjoining fields. 
ONE NIGHT'S RAIN-STORM.

It is both interesting and instructive to walk out after a heavy summer's rain and see the small, muddy rivulets running in almost every direction, following wagon ruts in the open roads, plow-fur-

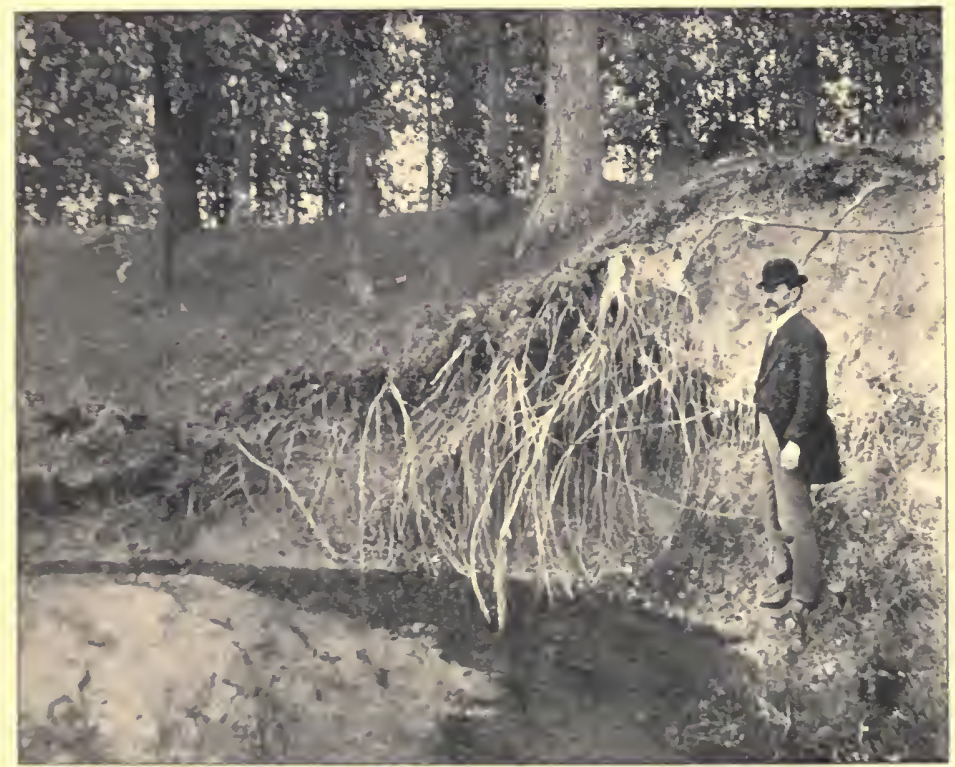

SOIL-WEARING ALONG THE BROOK.

rows in the fields, and mole-tunnels everywhere. Last night's heavy rain washed from about an acre of newly plowed ground fully a ton of soil, which settled by the roadside at the corner of the field. 
It reminds one of the delta of the Nile or the Mississippi. Farther down the road are hundreds of tongues of sediment a few inches wide and several feet long. They have left little gullies from which the earth has been washed. The main ditch, which receives all this water, from both east and west, is about six feet deep and ten feet wide. The muddy water is rushing wildly down its channel this morning, and will be in the Wabash before many hours. In some places the banks are so low that some of the water flowed out into the open fields and there, becoming quiet, left a thin sediment of fine mud. A wide board, which happened to be ly:ng in a pasture close by, was covered with a sediment of soi, about half an inch thick. The force of gravity impels the water onward to the larger streams, and draws it down into the earth, but at the same time it is pulling still harder on every particle of the heavier earth and brings it to rest whenever the water slackens its speed.

Not only is the earth from the cultivated fields and the open roads thus torn loose and carried away, but the banks and beds of the small streams themselves lose their share. During some rainy seasons, this amounts to nearly a foot each month. A small elm tree which stood in firm soil a month ago on the bank of the ditch just mentioned, was so undermined by the action of last night's freshet that only a few roots on one side are holding it to the soft mud. It is not able 
to stand erect any longer, but will soon lose its entire hold, and drift down the current to lodge against some neighbor's cross fence. In a similar manner full grown trees have been dug out and can be seen floating down our large rivers in times of high water.

MOVEMENTS OF WATER IN THE SOIL.

On dipping a marble, a pebble, or a pencil in water it will be seen, on taking it out, that a thin film of water adheres to it. A dry pebble, touched against the one already wet, will take part of the water film away from the first one; and a third, touched against the second, will do likewise; and so on, each taking a part of the water and holding it to itself. A force within the earth, called gravity, pulls everything downward; but each little grain of soil has a power within itself which acts against gravity, and keeps a part of the rain falling upon the earth from escaping too fast. This power that pebbles, grains of sand, particles of fine earth, and a great many other things have of drawing a film of water around themselves is called surface tension, or capillarity. It is a force just as truly as gravity is, and plays a very important part in agriculture.

It will be found, however, that those same things which were covered with this thin film of water, will, if left exposed to free air for a short time, lose the water adhering to them and become pertecisy 
dry. It is the air which takes the water away. The air has a power within itself of taking water away from things. This is called evaporation, because the water thus taken by the air can no longer be seen, but takes the form of an invisible vapor. The power of evaporation must, in one sense, be stronger than either surface tension or gravity. Surface tension pulls water away from gravity, yet the vaporizing power of air takes it away from both. These three forces acting together on water in the soil are the main ones with which the farmer has to deal. Surface tension and evaporation are not studied or understood so much as they should be in order to get the best results from the cultivation of the soil.

WHERE THE WATER GOES.

Water falling upon the earth either flows away or sinks down to be kept in store for plants. If the soil be already filled with water, most of it runs away; but when the earth is dry, and the rain does not fall too fast, nearly all of it is absorbed. During the winter season, when little evaporation takes place, on account of the low temperature of the air and the frozen condition of the soil, a great amount of water accumulates. Some of it is kept within a few feet of the surface and some sinks very deep, according to the nature of the soil below the top layer, that is, the subsoil. If the subsoil is of a loose, open nature, like sand or gravel, the 
water will sink through it very rapidly; but if it is a stiff clay, it will be retained for a very long time, generally till the next season's growth of plants can use it.

Dry ground which is wet, say four inches deep, by a rain of one day will be found to be wet six or eight inches by the next day. The grains of earth had so much water clinging to them that they could not hold it all firmly; so gravity and the surface tension of the grains below pulled some of it down still further. A limit, however, is soon reached, and that same water starts on an upward course, due to evaporation at the surface. The top layer of soil grains gives up its moisture to the air, while at the same time more is drawn by capillarity from the ones below, till all the water has passed back to the air whence it came.

Not all of the water held by soil escapes into the air if plants are growing there. They take it up with their roots wonderfully fast. If their roots do not go down to where all the water is, the surface tension of the soil-grains pulls it up to them, and this is the useful office of that wonderful force. A good example of surface tension can be seen along the margins of streams and other bodies of water. When the banks are dry, it will be noticed that the earth is wet several inches above the surface of the water. Posts and trees standing in the water are also moist above the water surface. The 
moisture is drawn upward just as the oil is drawn by a lamp wick.

Another important fact should be mentioned regarding the capillary movement of water in soil. Water is the greatest of solvents, that is, it dissolves more substances than any other. So, when water sinks into the earth, it dissolves out many of the ingredients of the soil, especially the plant foods, and these would be permanently lost were there no such power as surface tension to bring it back again in reach of the roots of plants. Every one knows, of course, that warm water has greater dissolving power than cold water; so, when the chilly winter rain fills the earth with stores of water, it does not carry down much dissolved material with it; but when summer comes, with its plants, and its thirsty, warm air to cause evaporation, that same water is drawn back to the surface, dissolving as it comes nutritious substances from the deeper soil and leaving them at the place most needed. Then, too, the warm, summer rains which dissolve so many rich substances of the top soil, find it laced and interlaced with the roots of growing plants to catch it before it can get away.

The soil, in its natural state, such as that of a forest, sees to it that all these forces are equally balanced, and that there is little waste; but, in the cultivated state, the conditions are so changed that the soil soon becomes poor if great care and wisdom are not exercised. 
RETENTION OF SOIL WATER.

It is a fact that, during the average year, there is not enough water in the ground for the production of as large crops as it is possible for the soil to yield. It is important for the farmer to cultivate the soil so as to keep as much water as possible in store for plant growth. In many cases, the water is allowed to escape so rapidly that only a partial harvest is the result. It escapes from the soil in three ways: by soaking downward, by evaporation at the surface, and by being absorbed by the roots of plants. The last, however, is the most desirable, especially when a useful crop of plants is being grown. It is difficult to prevent the soaking downward; for, as has been said, it depends largely upon the nature of the subsoil. During most seasons there is not enough water in the soil for much soaking away to take place. Not all of the water falling upon the ground gets a chance to soak in. Often the field is left for the winter so smooth and compact that the rains and melted snows quickly run away.

WHEN PLOWING BENEFITS SOIL.

Experience has proved that plowing the ground late in the fall helps to catch and retain water. The plowing leaves the ground loose, rough, and open, so the winter snows and rains are caught and retained in the many small cavities due to the 
plowing. It is often in a better condition, too, for early spring working than ground not plowed in the fall, and an early and successful crop can be started under more favorable conditions than would otherwise be possible. When it is dry enough to work, a good harrowing generally will reduce it to a smooth mellow condition, giving it the power to retain the largest amount of heat and moisture.

It is a well known physical fact that the more surface a given quantity of matter presents to the air, the faster it will dry out, or allow evaporation to take place. So, when it is desired to retain as much water as possible in the soil, the surface should be left smooth and level. After the ground is plowed, but before the crop is planted, this is best done by harrowing it down to a moderately fine powder. With crops such as corn and potatoes, which require cultivation after being planted, cultivators should be used which leave the soil as level as possible. Rows of plants left in ridges, or hilled up, exposing so much surface to the air, thus allowing the moisture to escape by too rapid evaporation, generally suffer from lack of water. Some root crops, if the soil be of a close, heary nature, require this kind of cultivation in order to get the soil loose enough for them to expand in, but care should be taken to prevent a complete drying out.

If the store of water which sinks into the ground during the winter is to be relied upon for the summer's crop, it is essential to plant as early as the 
weather will permit, so that none may be wasted by evaporation, or used up by weeds before the desired crop begins to grow. Early planting is generally best, for the roots of plants not only drink in their full share of water early in the season, but the ground is soon shaded by the growing leaves crowding out the weeds, which would claim a part of the soil nourishment. They also prevent early winds from drying the soil by not allowing them such free access to the surface, from which they take away the moisture very rapidly. All have noticed the drying effect of -wind, even when the sun is not shining. It often does its work as rapidly during the night as during the day. A hedge-row, a fence, or even a strip of ground with a higher growth of plants, will so break the force of wind that little loss will result. Winds are beneficial in many ways, but a very mild one may do a vast amount of damage.

SOIL AIR.

Surrounding the entire earth is a layer of air many miles high. It is invisible and very light; yet, on account of its great volume, gravity exerts such a pull on it that it presses heavily, about fourteen pounds to the square-inch, everywhere upon the surface of the earth. It presses heaviest, of course, upon the lowest places. Air, which is so essential to plant and animal life, and to the formation of mineral compounds, is composed mainly 
of nitrogen and oxygen-about seventy-five per cent of nitrogen and twenty-five per cent of oxygen. It also contains small amounts of other elements and compounds which will not be spoken of here. Air is just as essential to soil as water is; and, although it cannot be seen entering and leaving, yet the soil breathes just as truly as plants and animals do. That soil does contain air may be found by filling any tall vessel with dry earth and pouring water on it. Bubbles will be seen to escape as the water sinks. The air which filled the spaces between the earth particles was replaced by the heavier water and escaped as bubbles at the surface.

The roots of most plants require air just as their leaves do; and if in any way they are deprived of the supply, the entire plant will die. When a field, with germinating seeds or a growing crop, is flooded for several days, great injury or total destruction will result. This is due to the water's shutting out the supply of air which is so essential to germinating seeds and growing roots. Seeds contain compounds of such a nature that oxygen is needed for their transformation before they can be used by the growing sprouts, and the air has to supply this needed element.

\section{WHY CULTIVATION IS BENEFICIAL.}

The rapidity of germination and growth depends to a large extent upon the quantity of air supplied 
to the soil. A loose, open soil allows air to enter it more freely than does one of a close texture; but most soils tend to pack and become less porous after the crop is planted. Some means, then, must be resorted to so that good soil-breathing may be restored. This is usually done, with crops which admit of it, by cultivation. In plowing the ground between the rows of plants, the broken-up and falling earth catches the air and drags it down into the resulting spaces. If the roots of the crop go deep into the earth, then the deeper the cultivation the better for rapid growth.

Sometimes a field of corn, or other crop, is not cultivated because the weeds do not affect it; but frequent cultivation should take place for air supply to the roots, and also for the conservation of moisture, even when all weeds have been destroyed. It is not only necessary to supply air to the roots of plants during their early growing condition, but at all times, from germination till fruiting.

In a compact, water-filled soil, no air can circulate. Water always contains some air in solution after falling as rain, but the amount is small, and its free oxygen is soon exhausted by the roots of the growing crop. If, however, there is a deep, porous subsoil into which the rain may quickly sink; or if the field is underdrained well with tiling, the water runs away quickly, leaving empty spaces into which gravity pulls the air so that the needed oxgyen and nitrogen are supplied. It is 
quite essential, too, thus to get rid of the surplus water, especially during very wet springs and summers, for, besides opening up a means for the free circulation of the air among the spaces left by the vacated water, the soil is left warmer for early germination and growth. In the discussion further on, it will be shown that water which has to leave the soil by evaporation at the surface makes the ground so cold that the life-activities of plant:i are retarded.

EFFECT OF AIR PRESSURE.

The pressure of the air upon the surface oi the earth constantly varies. An instrument calles the barometer measures the pressure, and no two days have exactly the same amount; in fact, there is always a slight, and often a great, variation for two hours of the same day. Various causes produce these changes; the main one being the unequal heating of the atmosphere.

Now, when there is great air pressure, the water in the ground, if there is any near enough the surface to be affected, is pressed further down by the added force, its place being taken by air, producing a downward current. When the pressure of the air becomes less, the force of the confined water presses it back, forcing the air with it, and thus is produced an upward current. Not only does this change take place from above, but in many places from beneath through tile drains, and 
other underground channels; but, from whatever source, there is always some circulation of air in the soil from atmospheric changes.

Then, too, there is a small circulation in the top few inches during warm, sunshiny days, when the soil is cultivated so that it is not too compact. Air has such great power of expansion that, under the added heat of noonday, come is forced out; but, cooling and contractins during the night, it returns.

Soils which are open and well drained, may have too much ventilation, from which injurious results may follow. The air which enters the earth goes there for the purpose of supplying the roots of plants with food directly, or it acts upon the minerals in the ground and changes them into plant food. If the air circulates too freely in the soil, so much food is formed that the plants cannot use it all immediately, and some of it goes to waste. Some is dissolved and washed downward by the next rain beyond recovery, and some is of such a nature that it soon loses its identity, and thus becomes unfit for use. It should be the aim to keep such soils as moist as possible at the surface, and the pores well filled by the right kind of cultivation.

SOIL TEMPERATURE.

The soil receives its heat in three ways:-from the interior of the earth, from decomposition of 


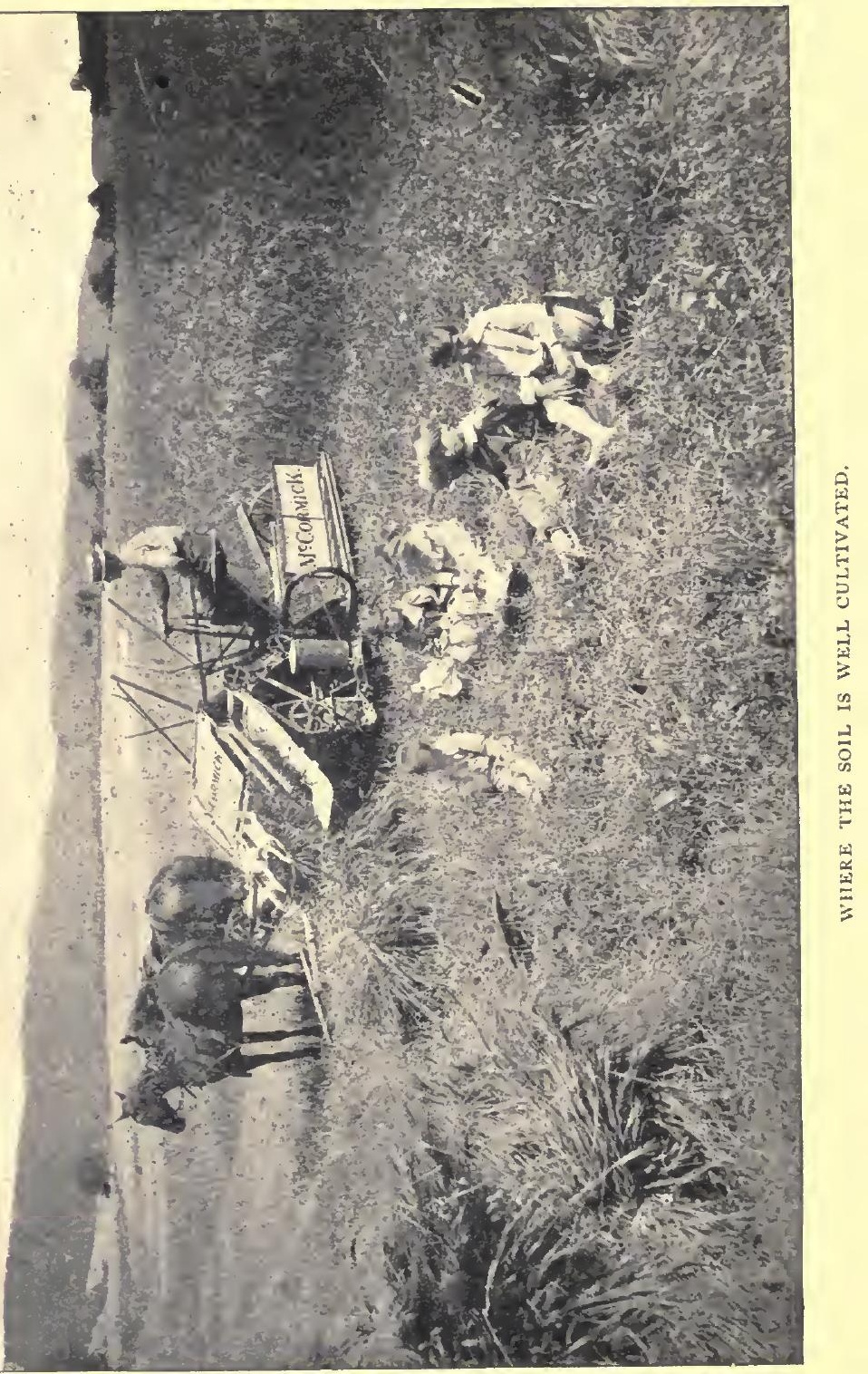


organic matter, and from the sun That received from the interior of the earth is so small that it may not be considered here. The greatest amount comes from the sun. This can be easily noticed by observing the difference in temperature between winter and summer, and day and night Both light and heat reach the earth from the sun, but light rays have little to do with soil conditions; on the other hand, heat rays play a very important part.

When light or heat falls upon an object it is either reflected away or absorbed, according to the color and other physical conditions of the object upon which it falls. Light-colored objects reflect away the most and dark-colored objects absorb the most. A dark-colored object that absorbs heat is, of course, made warmer thereby. So the darker the color of soil, other things not being considered, the more heat rays will it absorb and consequently the warmer it will be.

Some things are heated very quickly but give up their heat just as quickly; and those which are slow in being heated, give up their heat slowly in return. Water is a substance which absorbs heat slowly and retains it a long time. The boiling kettle of water remains hot a long time after the fire goes out and the stove becomes cold. So it is with soils; some become very hot during the middle of the day, and cold at night. Those which are heated only moderately during the day, keep a 
considerable amount of the heat over night. Sandy soils are easily heated, but are not on the average the warmest.

\section{RELATION OF HEAT TO THE SOIL.}

The relation of heat to the soil is important. All living things, both plants and animals, require a certain amount of heat in order to live and grow. With the higher animals, a great amount of heat is necessary. The bodily temperature of man and many other animals must be nearly $100^{\circ} \mathrm{F}$. at all times. If it rises a few degrees higher, or falls a few degrees lower than this, death, or serious results follow. Plants, like some of the lower animals, can endure greater changes of bodily temperature; but there is a high and a low limit beyond which they cannot pass and live. If the bodily temperature becomes either too high, or too low, life-activity ceases permanently.

Seeds germinate better in a warm than in a cold soil. If the ground is too cold, they decay on account of germs that can work at a lower temperature. Some seeds sprout best at a temperature of nearly one hundred degrees F. Good results, however, follow with a soil temperature of $50^{\circ}$ to $75^{\circ} \mathrm{F}$.

For germination of seeds, and growth of young plants, it is necessary for the soil to be warm to a depth of a few inches only. As the plants grow larger and send their roots down deeper, then 
there is a necessity for deeper soil warmth. If the soil were warm to a depth of several feet in early spring, before plants have time to send their roots down, a great amount of valuable plant food would be dissolved on account of the increased temperature of the water, and hence lost. So nature has provided that the soil be warmed downward only as fast as the roots of plants can use it.

Soil in a natural state, such as that of a forest, has a most wonderful means of regulating its own temperature. Covered with a thick layer of leaves each autumn in our latitude, it is protected from sudden changes, both on account of the nonconducting property of the leaves themselves, and also of the confined air among them. Early spring plants have learned to grow there, even before the frost is quite all out of the ground, and blossom before the needed light for their full development is shut out by the dense foliage of mid-summer. Trees do not put forth their buds and leaves till the last trace of frost has left the ground and air. The ground is kept cold for their own good.

Since plants do best in a warm soil, and one that does not admit of too sudden changes of temperature, it remains with the farmer to regulate the conditions which govern them. As heat is taken from the soil in evaporating water at its surface, it should be left in such a condition that as little evaporation takes place as possible. Every unit of heat spent in evaporating water leaves the soil just 
so much colder, and a consequent slower plant growth results.

CHEMICAL COMPOSITION AND KINDS OF SOIL.

Geologists inform us that the present crust of the earth has been a long time in the process of formation. Early rock-formations have been broken up and decomposed by later actions. Water, cold, heat, and glacial movements have been the great causes in breaking up the surface rocks and leaving them in a fit condition for the growth of plants.

Soil, in order to yield its ingredients quickly as food for plants, must have its grains so fine that a great amount of surface is exposed for the combined action of roots and water. A cubic foot of solid stone might contain all the necessary food for plant growth, yet so little of its surface is exposed that only a small per cent. of it could be dissolved for a season's growth. By a very simple mathematical law, it can easily be found that the same cubic foot of stone, when broken into small pieces, will present, instead of six square feet of surface, several hundred; and, if reduced to particles fine enough, such as that of most soils, several thousand square feet.

This not only allows the roots to penetrate more easily, but the surface tension of the particles gives soil a greater water-holding capacity, one of its most valuable properties. The fineness and coarse- 
ness, then, of the soil grains is one means of determining different kinds of soils. However, there are other things to be taken into consideration.

Some rocks, such as granites, are so hard that, when ground to pieces, they are not easily reduced to a fine powder, but remain hard and sharp grains of considerable size. Such are sandy soils. Sand grains are not only comparatively large, but of such a nature that they are not readily dissolved; hence, they give up their food very slowly. Other rocks, such as limestone, and the clays, are easily reduced to a fine powder, forming soils of very small grains, with a great water-holding capacity.

Soils are called sandy when a large per cent. of sand enters into their composition; and clay soils, if they are composed largely of clay. Where sand and clay are mixed, it gives a sandy clay, or a clayey sand according as the sand or the clay predominates.

"Light" and "heavy" soils are terms applied on account of the ease or difficulty with which they are worked, and not on account of weight. A sandy soil weighs more per cubic foot than a clay soil, but it is called a light soil on account of its loose texture; and a clay soil heavy on account of its stiffness.

Humus soils are those composed mostly of decaying organic matter, the remains of plants and animals. These soils predominate in regions where organic decomposition goes on but slowly. The best examples of humus soils-are peat and black 
muck. These soils are such because of the great amount of water they contain, and of their antiseptic nature, shutting out those organisms which cause decomposition. They become very productive when drained, as this allows air and decomposition germs to enter them.

It must be borne in mind that the humus soils are the most unstable. In the decay of the organic matter of which they are composed, part of the products go back to the earth as ash, and part as gases to the air from whence they came. All organic substances remain but a short time as such, then decompose into their original elements, to be again taken up and passed through the cycle of life.

ELEMENTS COMPOSING THE SOIL.

Each rock has its own particular composition, and the elements composing any single kind are so few in number that they are not adequate for the many demands of plants; but there has been such thorough grinding and mixing in the processes of soil-building that many different kinds of elements have been brought together and can be found in almost all places. The elements composing the soil rarely occur in a free state, but are usually combined with other elements to form compounds. Some of the most important elements are-oxygen, hydrogen, nitrogen, sulphur, silicon, phosphorus, chlorine, calcium, aluminum, iron, sodium, magnesium, and manganese.. 
Oxygen occurs in the soil in a free state, and also combined with nearly all of the other elements. Combined with silicon it forms quartz, of which sand is made and which is so abundant all over the earth. Quartz is so abundant that it is estimated to compose nearly half the rocks of the earth.

Hydrogen seldom, or never, occurs in a free state in the soil; but, combined with oxygen, forms the familiar compound water, which is absolutely essential at all times, and serves plant growth in many ways.

Nitrogen, although so abundant in the air, occurs in very small quantities in the crust of the earth. It is a very essential soil ingredient when combined. It is brought and fixed in the soil through decaying organic matter, and by germs on the roots of plants of the pea family. It also occurs combined with sodium and potassium as nitrates, and is often applied in a pure state to the ground as a fertilizer. Nitrogen has very little attraction for the other elements and compounds, but the small germs growing on the roots of clover, peas, and beans have the power of extracting it from the air and fixing it as a compound in the soil. There it does a vast amount of good in replenishing the soil with new plant food.

Carbon occurs in the soil mostly as a part of organic matter. It exists in the air combined with oxygen as the well known gas, carbon dioxide. In this form it is taken up by the leaves of plants, 
built into plant tissue, and passed on to animals. In the process of organic decay, carbon again unites with oxygen and passes back to the air. It also occurs as carbonates with some of the metals, such as calcium and magnesium.

Iron occurs both in a free state and combined with some of the other elements, especially oxygen and sulphur. It is found widely distributed through all soils in such quantities that it is rarely necessary to apply it as a ferrilizer. It does not enter to any great extent into the composition of plant tissue, but is thought by same to aid in the processes of growth.

The other elements are found in the earth as compounds, and enter into plant structure. When they are lacking to any great extent it is necessary to supply them to the soil in some form or other.

\section{RELATION OF SOME SMALL ANIMALS TO THE SOIL.}

Besides giving up their bodies in decay to add to its richness, some animals do not a little in improving the texture of the soil, and making it more open for the free circulation of air and water. Such animals are those that live in the rround permanently, or those that burrow into it for shelter.

The crayfish, in many places, has the havit of digging deep holes in the ground, and bringing up the earth from a depth of several feet. This earth, or mud, is generally built into a sort of 
tower at the entrance of the hole, but in time is knocked over and becomes mixed with the upper layers. Soil thus brought to the surface is fresh and productive, and takes the place of that which has become exhausted.

The crayfish holes, too, benefit the soil. They permit a free circulation of air to greater depths than would otherwise be possible. The falling-in of their walls produces a loose column of earth down which the roots of plants easily grow for fresh supplies of food and water.

Ants are very common as earth-mixing animals. A colony of ants will bring to the surface during a single season enough earth to form a mound several inches high, and two or three feet in diameter;in many cases, they make much larger ones. They carry into their galleries animal and vegetable matter which finally decays and becomes a part of the soil.

Some rodents, and other small fur-bearing animals, dig in the ground not a little. The mole lives in the ground all the time, and its entire make-up is well suited to the life it leads. It tunnels the ground in every direction, making it loose and open for the free circulation of air and water. Gophers, mice, prairie dogs, and many such animals dig in the ground more or less and do valuable work in stirring the soil.

The most valuable of all animals in soil-making is the common earthworm, or angleworm. It is a 
small creature, but such countless numbers are con. stantly at work, when the soil is moist enough and warm enough, that the amount of fresh soil brought to the surface by them annually is enormous. The earthworm burrows through the soil for the organic matter which it is able to get from it. In order to get the food from the soil, it takes the soil into its stomach. This process not only grinds the soil into finer pieces, but increases its richness.

Bringing to the surface an amount of soil that can be easily measured, it has been definitely proved that the earthworm completely mixes and re-mixes the soil in a definite number of years. It can truly be said that this little animal is one of the farmer's best friends.

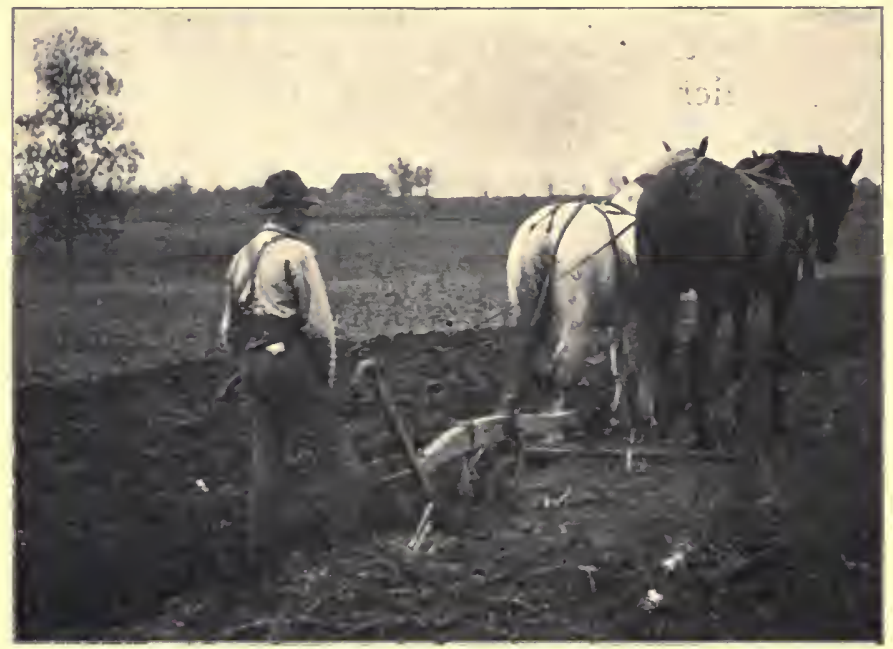




\section{CHAPTER II.}

\section{PLANTS.}

Plants have life and motion. Their struggle for existence. Their structure. How complex plants develop. Organs and functions. Why plants have so many roots and leaves. Structure and function of leaves. How a leaf works. Arrangement and shapes of leaves. The storing of food in plants. Importance of perfect seeds. Individual plants - Indian corn, potatoes, peas, and beans.

Under the study of soil it was found that, during long ages, the earth has produced a layer of decayed and ground-up rock, varying in thickness from a few inches to several feet. This soil covers the face of the land and is the natural home of most plants.

Some of the first and simplest forms of plants have always lived in water. They adopted this mode of living when the earth was new and before any soil was formed. Their food is dissolved in the water in which they live. In this manner of living, they'simply float upon the water, a part of the plant being below the surface and a part of it above. Such plants as seaweeds of the oceans, and the small duck-weeds of our ponds have all the conditions necessary for plant growth and development. They have earthy material dis- 
solved in the water, and free air and light above.

The largest and most beautiful kinds of plants, however, cannot grow in this way because of the liquid and unstable condition of water. Water plants cannot raise their trunks and branches into the air, as oaks and cedars do, because they have no solid support for their roots. All they can do is to lie flat upon the water and float.

The soil, then, is a more ideal home for plants than water is. In it they find food, and a firm anchorage for their roots, enabling them to raise their trunks high in the air, and spread their branches, making forms of symmetry and beauty. It is true that plants cannot move much when rooted to one spot, but food and drink come to them in ample quantities. Other conditions are such that they are able to grow into larger forms.

\section{PLANTS HAVE LIFE AND MOTION.}

Plants are to be thought of as living beings. They are just as much alive as animals, but, being of different structure, they manifest life in a different way.

Though rooted to one spot, in most cases, yet plants do move. They not only move in the space in which they grow for a season, or number of seasons, but move from place to place. They do so for new food-much the same as animals do. Every breeze causes a part, or the whole, of a plant to move. Its leaves, branches, and stem are not 
aimlessly fluttering, swaying, and bending, but are changing their positions to get as much air and light as possible. Some plants, such as sunflowers and field peas, are great lovers of light. They bend the upper parts of their bodies toward the sun, and follow it in its daily course. They do this so that their leaves and blossoms may get a large amount of light and heat. Others, such as poplar trees, are so made that their leaves flutter in the slightest breeze, thus presenting first one side then the other, to the air and light. Such plants do not have as many leaves as those that have less movement. Each leaf does a large amount of work, hence there is a saving in the amount of exposed surface.

Besides movement in one place; plants-such as ferns, Solomon's seal, blood-root, and many others, move slowly from place to place. They do so by means of their underground stems. Such stems grow horizontally in the ground in the direction of the most plentiful supply of food. At one end of the underground stem is a large bud. This bud, in growing, pushes continually forward, while the opposite end gradually dies away. All along the stem are lateral buds. These yearly send up branches or leaves for the necessary slipply of air and light, and the production of seeds. Such plants are perennials, and live the longest; in fact, they practically never die, except in cases in which the underground stem is destroyed. They simply 
grow forward year after year, constantly adding new growth at one end and dying at the other.

Such perennial underground stems can be found fresh and alive in the ground during winter. They afford excellent means for plant study during that season of the year when the whole face of the earth seems to be swept clear of all traces of life. A little digging in the earth in the right places, even when the ground is frozen solid, will reveal surprises of fresh and expanding buds of rare beauty and the richest colors. They can be placed in jars of earth in the house during the latter part of winter, when new growth will take place long before any signs appear out of doors.

Then, too, plants, or rather their children, move from place to place by means of the many devices for scattering seeds. Plants must not only provide for their own life and growth, but also for their children. Seeds produced by a plant do not fall upon the ground where the parent plant stood, but are carried to new places. The soil which supplied the parent plant, especially if it be a plant which lives for many years, such as an oak or maple, has all it can do to supply nourishment for itself. The young seeds are sent away to new and unoccupied fields.

THE STRUGGLE OF PLANTS FOR EXISTENCE.

Plants have to struggle for life just as man and other animals do. It is a well-known fact that plants usually crowd one another. Thus none are as 
large and perfect as they otherwise would be. In many cases, some are forced out of the race entirely and cease to be. The strongest and first in the field always win. This is one of the main principles in agriculture, one class of plants being given possession of the soil to the exclusion of others. Corn, potatoes, and like crops are plowed and cul-

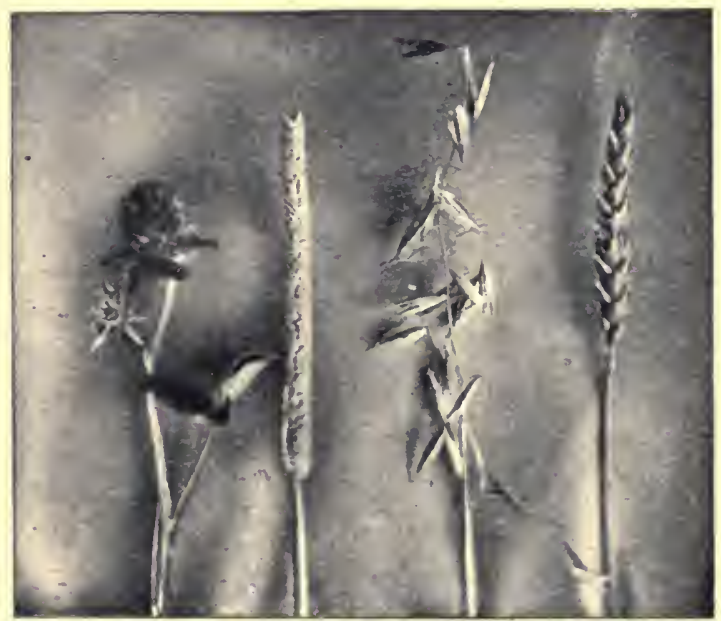

RED CLOVER, TIMOTHY, OATS, AND WHEAT.

tivated after the plants start to grow, so that other plants cannot crowd in to take away a part of the light and food. In other words, cultivated plants do not have to use part of their strength in struggling with enemies. They are enabled to use all of it in growing larger and more perfect. 
Those of the same kind, too, struggle with each other. Each plant requires a certain amount of space and food for its complete development. When there are so many growing together that the space for each is very small, none grow to much

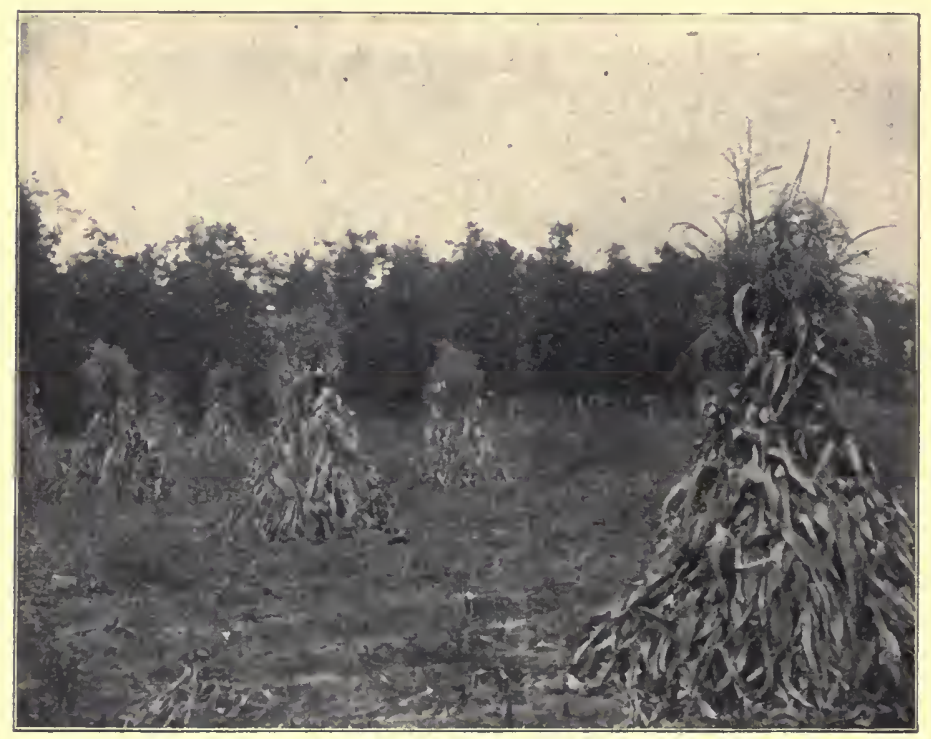

AUTUMN CORN FIELD.

size. The fruiting in such cases is imperfect or altogether wanting. Corn planted a few feet apart, and two or three stalks together, will grow from seven to twelve feet high, producing large and 
well-developed ears. When it is sowed as thick as wheat or oats, although no other plants grow with it, it will attain a height of but three or four feet, with but the indication of ears and no seeds at all on them.

Plants require space in proportion to the size of the full-grown individuals. Large plants require much space, and small plants require little space. Thus clover, timothy and field peas are planted but a few inches apart because the full-grown plants are small and require little food and light. These plants, too, when started to grow in soil in which all weeds have previously been destroyed, so take possession that no weeds are allowed to grow. The reason for this is that most of the air and light are shut out. As soon as the ripened crop is removed, thousands of weeds spring up, showing that the seeds were there waiting for an opportunity to germinate.

Plants cannot be considered as having the power to reason, yet they spend no energy in germinating when the conditions are such that growth would be impossible. They behave in many other ways just as wonderful as this.

STRUCTURE OF PLANTS.

Like animals, plants are either simple or complex in structure. A simple organism is one in which the life processes are carried on in a single cell, or a few united cells. A good example of a cell is the 
egg of a bird or of an insect. Some of the simplest plants resemble very much the soft egg of an insect. All the life-activities are carried on by the

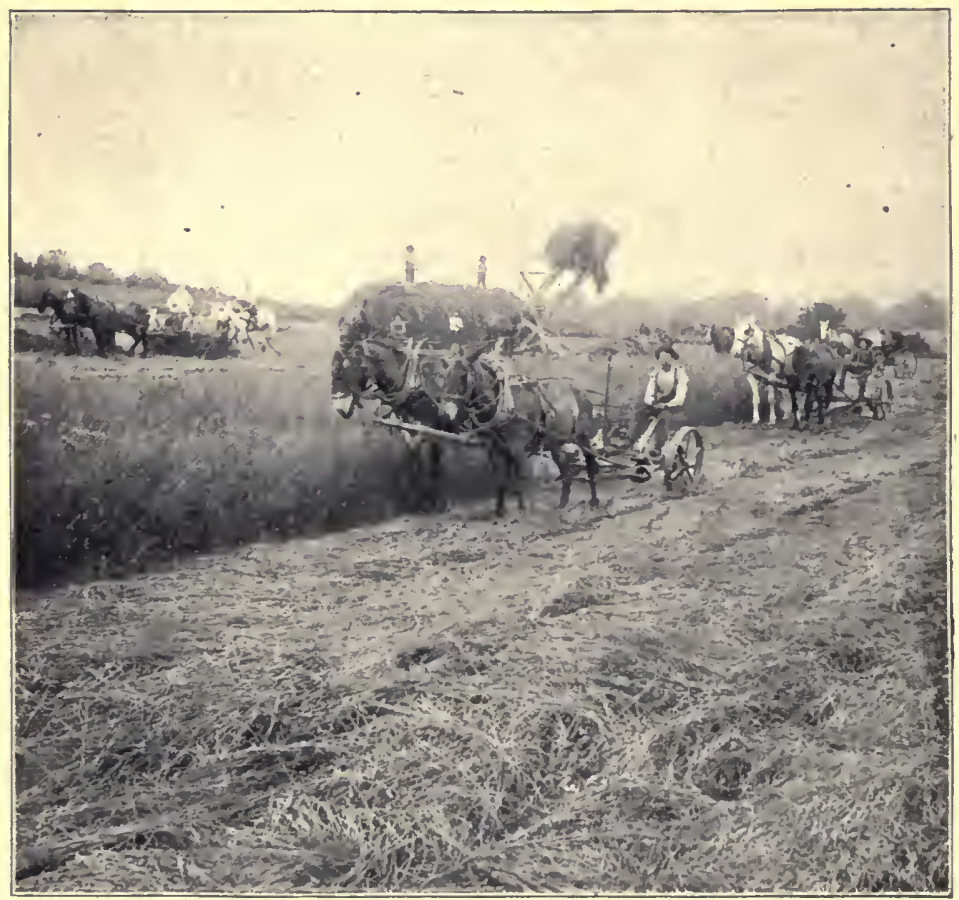

HAY CUTTING AND STACEING.

whole mass. They have no special organs, such as roots for drinking and leaves for breathing. The single cell. is roots, leaves, stem, and branches all in one. Any and all parts of the plant body eat, 
drink, and digest at the same time. No one part seems to be different from or better than another.

With plants of a more complex nature, there are special organs for the production of seeds, and from these new plants grow. Simple plants are produced by the simple cell dividing into two parts. Each part becomes a perfect plant and looks just like the parent cell. By and by these two divide in the same manner, giving rise to four plants. These four again divide, giving rise to eight plants, and so on. An infinite number might thus come into existence were it not for the fact that many are destroyed, and many more die from the lack of food and other things necessary for such a life.

Most of the very simple plants live either in water, or on substances where a great deal of water is present. If from any cause the moisture disappears, the plants cease to grow; but most of them have the power of reviving on the return of the supply of moisture.

\section{HOW COMPLEX PLANTS DEVELOP.}

Complex organisms are those that have special organs set apart for special purposes. Thus, instead of drinking in water all over their surfaces, as the simple plants do, complex plants have roots, by means of which they drink. These roots are especially fitted to do that work, and they do it well because they have few other burdens imposed upon them. Instead of breathing with the whole 
body, higher plants have organs especially fitted for that work. And, instead of dividing and breaking to pieces in order to produce new plants, those of complex structure have special organs for the production of seeds. These seeds germinate and become new plants without any disturbance to the parent plant.

Complex plants might be compared to a civilized community. There each person does some particular thing instead of everything necessary to life. The baker can bake good bread because he has ali his time and strength for that one thing, and the tailor can make good clothes for the same reason. The same is true of the higher plants. Leaves can breathe well for the plant because they give all their time and strength to that one office.

Simple plants can be compared to a savage comInunity where every man is everything-carpenter, tailor, shoemaker, butcher. Nothing in such a community is done well because there are so many different things for each man to do. Because of this division of labor, complex plants are usually the largest and finest types.

Cells form tissue, and tissue forms organs. One of the main differences, then, between a very simple plant and a complex one, is that the simple plant consists of a single cell, and the complex plant consists of a very great number of cells constructed into tissue, and the tissue constructed into organs.

Plant cells can easily be seen with a low-power 
microscope in the thin, transparent tissue peeled from an onion. Cells large enough to be seen with the naked eye can be separated from the pulp of an orange.

ORGANS AND FUNCTIONS-ROOTS.

Plants drink with their roots. All living things require water, and plants are no exception to this

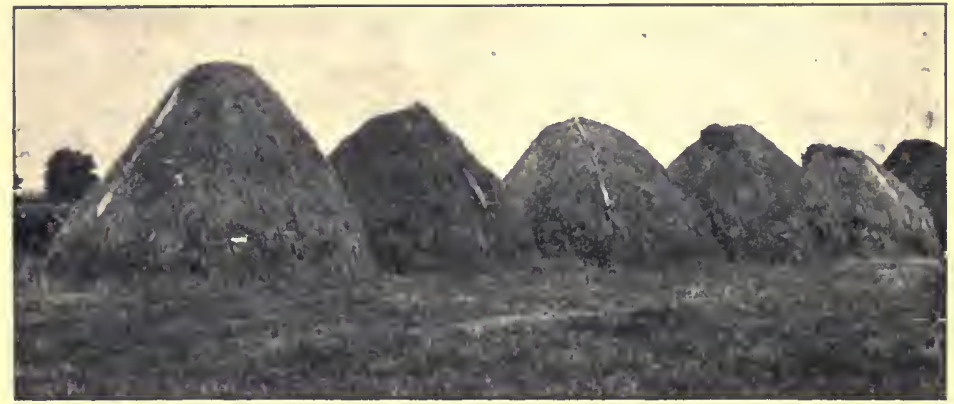

HAY STACKS.

rule. In fact, plants require more water for growth than animals do. The roots of a plant not only drink for it, but they hold it fixed to one spot, so that it may grow up into abundance of air and light. They keep its position against the wind and other things that tend to destroy it.

One part of a plant has a natural inclination for light, hence, it grows upward. The other part has an inclination for the soil and darkness; hence, it grows downward. Roots grow in all direct:ons is 
the soil, which is the great storehouse for water supply. It was formerly thought that plants drink in water with their leaves, but it has lately been proved that this is not the case. Plants will grow and mature without any water touching their leaves. This is so in dry regions, where irrigation is used to supply water. In irrigation the ground is flooded a few inches deep at stated times so that the roots are supplied with water. None touches the ieaves or blossoms. Abundant crops are harvested without the fall of a single rain upon the leaves of the plants. Similar methods are used in the growing of potted plants.

Roots penetrate the soil, pushing their sensitive tips among rocks, pebbles, and soil grains. The growing end of the root is the part that does the most drinking. The older part carries the water to the main body of the plant, which circulates it as sap. The sensitive ends of the roots are covered with fine hairs which grow out in every direction, taking up all food within their reach. They have great power of attracting water to themselves on account of their small size. The smaller the size of an object, the greater in proportion to its mass is its power of surface tension for the attraction of water. The little hair-like roots are constantly dying. New ones immediately grow out to take their places, so that all the small spaces in the soil are visited in their search.

Plants get far more substance from the air 
through their leaves than they do from the ground through their roots. The substances taken up by the roots are very essential, though small in amount. Water in the soil contains dissolved substances which are taken up and used by plants. They have the power of selection, to a certain extent, and exclude some things which are not conducive to growth. Some things, however, are taken into the plant structure by the roots which either retard growth or cause the plant to die. Common salt, for instance, when dissolved in water will kill most plants very quickly. It can be seen from this that right kinds of food should be in the soil, and that injurious substances should not be, if strong and vigorous plants are to be grown. Certain elements are necessary for the growth and development of a plant. If they cannot be secured, the plant will die.

WHY PLANTS HAVE SO MANY ROOTS AND LEAVES.

All plant food must be dissolved in water before it can be taken up by the roots. They have not the power of eating solid food as animals have. Instead of one large mouth, they have thousands of small mouths. These mouths are so small that they cannot be seen with the naked eye, hence solid food cannot enter them. Then, too, the food in passing up the stem and out to the leaves through the branches does not flow through a large tube like the digestive tract of an animal. It 
must pass through very fine, hair-like tubes, and among closely packed cells; hence, it could not possibly penetrate except in a dissolved condition.

This is the reason that plants have so many roots and leaves. The many small mouths make up a sum equal to one large one. An animal has one mouth, which serves the double purpose of eating and drinking. A plant has thousands of little mouths for eating, and thousands of still a different kind for drinking. A plant may have a dozen of its mouths completely destroyed, and still have enough left to eat and drink with. It is quite necessary for them to have so many mouths. They cannot move about, and the food in both air and soil is so widely scattered, and in such small quantities in any one place, that they could not gather in a sufficient supply if they were not thus provided.

The roots of plants are great lovers of water. Since it is their office to supply the plant with this necessary liquid, and in large quantities, too, they seem to know where it is, and grow in that direction. There is always water in some place in the ground. This is proved from wells in which water stands at various levels during the entire year. Besides, there is water held everywhere by the surface tension of soil grains. It never escapes, except by evaporation at the surface, and when it is taken up by the roots of plants. Plants, trees especially, growing near wells, sometimes almost fill up the 
cavity by their roots extending in search of water. They not infrequently grow downward forty or fifty feet after penetrating the walls of a well.

\section{LEAVES-STRUCTURE AND FUNCTION.}

If it can be said that one part of a plant is more useful than another, then the most important part is the leaves. They grow upward and outward into the air and light. They spread their flat bodies into numberless shapes, and the most beautiful forms. The leaves of most plants are very thin, compared with their other dimensions. It is necessary that they should be, since their function is to gather air and light, and to evaporate water. During normal growth, there is a great deal of water evaporated. Since the amount depends upon the quantity in the soil which can be absorbed by the roots and sent up to the leaves, plants in very dry regions have very thick, fleshy leaves, which expose less surface compared with the bulk of the plant. Such, for instance, are the cacti, whose native home is the dry, arid region of west central United States.

Some forms of the cactus plant have no true leaves at all. The large, green, fleshy stalk performs the functions of both leaves and stem, and acts also as a water reservoir from one rainy season to another. If these plants had thin and highly divided leaves, so much surface would be exposed that evaporation would carry away the water too 
quickly, leaving them to wither and die. Hence, plants in different climates and locations so shape their leaves as best to fit them for life and growth under the imposed conditions.

That leaves do evaporate water may be verified by placing a glass jar over growing leaves. Drops of water can soon be seen collecting on the inside of the vessel. One who has never looked into the matter will be surprised at the very great amount of water evaporated by a single leaf during a day of active life under good growing conditions. The reason that the amount of water evaporated by leaves of plants is not appreciated, is because it passes into the air in the form of an invisible vapor. Knowing, however, that a small potted house plant, with only a few leaves, easily drinks a pint of water each day, it will be readily perceived that, in proportion, many hundreds of pints must be drunk up and given off by the thousands of leaves of some of the larger plants, such as trees. Since the leaves of plants require so much water for evaporation, it is quite essential to cultivate the soil so as to keep as much water as possible in store for them during the growing season.

HOW LEAVES DECOMPOSE AND REBUILD.

It has been mentioned that water drunk in by the roots of plants and sent to the leaves, takes certain earthy material in solution with it to be built into the structure of the plant. Water has 


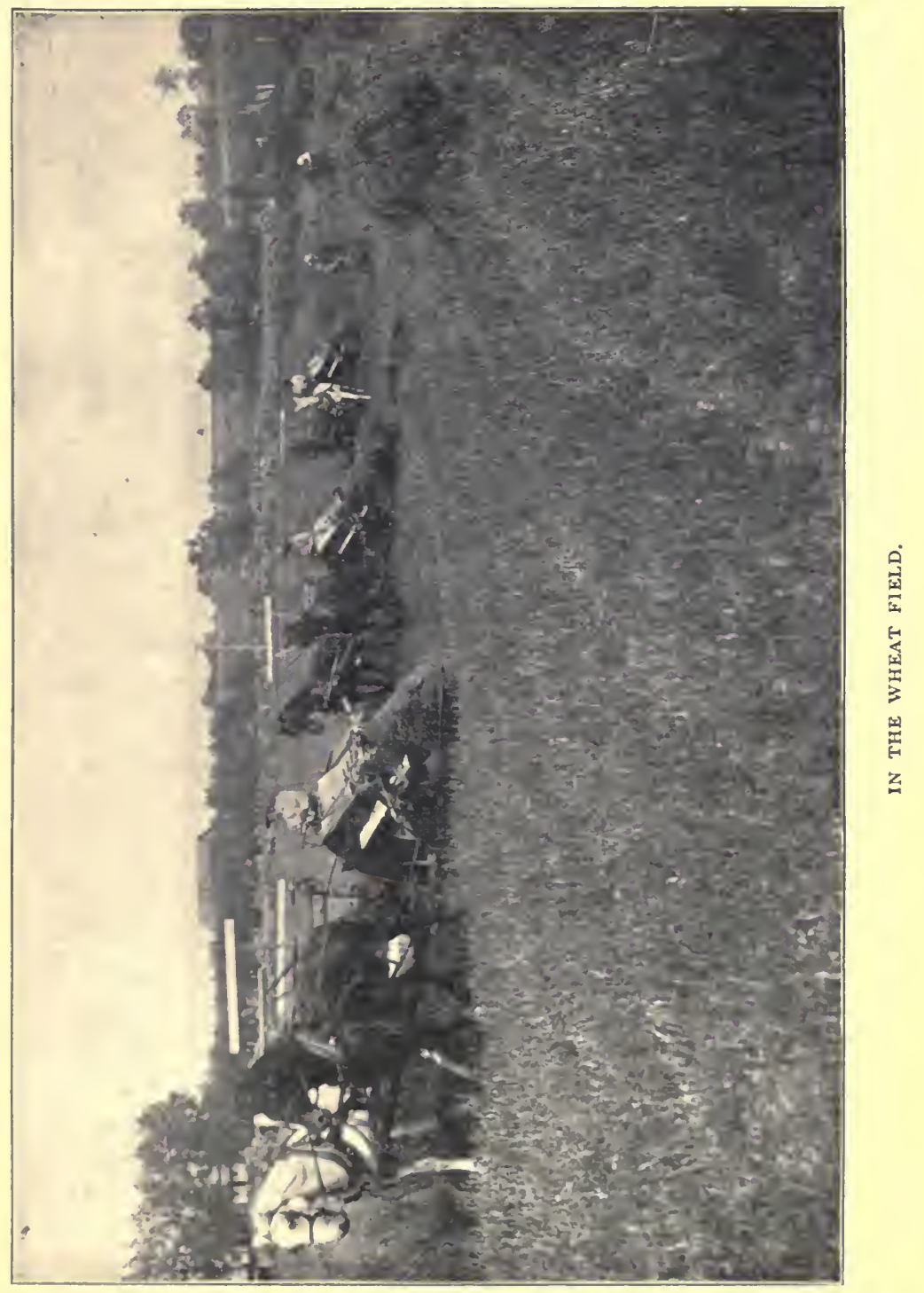


other parts also to play, and the leaf is the organ in which the wonderful work goes on. Water consists of hydrogen and oxygen strongly bound together. The leaf has the power of breaking them apart, and combining them with carbon to form starch, sugar, fat, and other substances composed of these three elements-carbon, hydrogen and oxygen. ${ }^{1} \quad$ The carbon is obtained from the carbonic acid gas of the air. Carbonic acid gas is composed of carbon and oxygen. Only a fraction of one per cent. of the atmosphere consists of carbonic acid gas, yet there is always some floating everywhere, and the leaves struggle hard to get every molecule that passes.

There is in every living leaf an active, green substance called chlorophyl. It has the power, under the influence of sunlight, to break-up water and cárbonic acid gas and form them into starch. The starch is changed into similar compounds with a different proportion of the atoms of carbon, hydrogen, and oxygen. The leaf, then, is the factory in which organic material is made; chlorophyl is the machinery, and sunlight is the motive,power that does the work. Organic compounds-or the compounds of carbon-can always be recognized from the fact that, on being heated sufficiently, a black, charred mass remains. The charred mass is carbon taken from the atmosphere by the growing

1 The formula for starch is $\mathrm{C}_{6} \mathrm{H}_{10} \mathrm{O}_{5}$, and for sugar $\mathrm{C}_{12} \mathrm{H}_{22} \mathrm{O}_{1}$. 
plant in the form of a gaseous compound. When, however, charcoal is raised to the kindling point, it burns, or oxidizes, and returns again to the atmosphere whence it came.

Besides starchy substances, leaves build up another substance called albumen. It contains not only carbon, hydrogen, and oxygen, but an additional element-nitrogen. The nitrogen is not taken from the air directly, but is brought up from the earth by the roots as a nitrate dissolved in water. There is far more nitrogen than any other substance in the air, yet leaves do not have the power of absorbing it. Nitrogen is very essential in the formation of albuminous substances, so that soils poor in its compounds yield very light crops of certain kinds of plants. Some plants-the seeds especially-are richer in albumen than others, and of course require more nitrogen in the soil. The sticky part of wheat flour is albumen, and there is a larger proportion of it in the grains of wheat than in Indian corn. Hence a good wheat-growing soil must necessarily be different in composition from soil in which corn is best grown. Wheat grows well in soil where clover was grown the previous season. The roots of clover have the especial power of extracting free nitrogen from the air and fixing it as nitrates in the soil, whence the wheat plants take it up and build it into albumen of the seeds. 


\section{HOW A LEAF IVORKS.}

There is busy work, and there are complex changes going on in leaves during the day while the sun shines. As soon as compounds are formed in the leaves, they are carried away by the circulation of the sap to all parts of the plant, to be built into tissue. Starch is not soluble, but sugar is; so the starch is transformed into sugar and carried by the sap to the places where most needed, and there changed back again to starch, cellulose, fat, gum, or some other similar compound. At night, of course, when there is no light, starch-building ceases, and the leaves stop taking in carbonic acid gas; but, as with animals, vital activity never entirely ceases so long as there is any life. During the night rest of plants there is a process, though less active, going on in the leaves similar to the breathing of animals, in which oxygen is taken in and carbonic acid gas given off.

It may be well to add here that there can be no life without a peculiar substance called protoplasm. It is called by some "the physical basis of life." Protoplasm is a watery, transparent, jelly-like substance, very plastic, and always in motion. It is composed of carbon, hydrogen, oxygen, nitrogen, and sulphur. It is the basis of animal life as well as of plant life. Plants build organic substances out of inorganic material, while animals consume or destroy such substances. From this it is very 
evident that plants appeared first upon the earth, and animals afterwards. Animals cannot exist without previous plant life. It is true that some animals eat nothing but flesh, or other animals; but all animal life would soon disappear from the face of the earth if there were no plants from which they could get the organic material.

The leaves of plants get most of the material for plant structure from the atmosphere, and only a small amount from the soil. It would appear, then, that the farmer need care little about the soil in which plants are grown; but the substances in the soil are absolutely necessary. Besides, the soil costs money, while the air is free to all. In the burning of a stove two things are necessary-fuel, and oxygen of the air. The fuel costs money, but the oxygen comes floating in without price. Nearly twice as much oxygen as fuel is used in the act of combustion. If it had to be paid for at the same rate as fuel, modern house heating would be very expensive. It is likewise true of ourselves, and the animals we raise-the food costs labor and money, but the large amount of oxygen costs nothing. So it is with plants-carbonic acid gas comes free, but land is scarce and high-priced. Besides, the air can never be exhausted of its supply, for all burning and decay constantly return enormous quantities of this gas to the atmosphere, to be used over and over again. 
ARRANGEMENT AND SHAPES OF LEAVES.

Leaves are arranged in various ways on the plant. Whatever the mode may be, it is always the best way of getting the greatest supply of air and light. Some are arranged in circles around the stem, the largest being at the bottom, and the others growing smaller toward the top. This arrangement is similar to that of the petals of the rose, and for that reason is called the rosette type. The mullein, garden cabbage, and bellflower are good examples of this type. With such plants the lowest leaves are not only the largest, but their leaf stalks are the longest, pushing out so as not to be shaded by the ones above. Instead of growing out directly beneath the ones above, they grow between them, thus securing a position where nearly all of the leaf is in full light.

Another type of leaf arrangement similar to the rosette is that of many climbing vines, the redbud of the pea family, and many other plants. In this type the leaves are placed very much the same as the shingles on the roof of a house. When the plant is in full foliage, they will actually shed water during a light shower. This arrangement is such that the spaces between the upper leaves let light fall upon the leaves below. It is thought by some that this habit, together with that of all kinds of plants whose leaves slope outward and downward, is for the purpose of carrying the water of rains 
away from the central part of the plant to the outer ends of the roots. In the rosette type, most of the water is directed down the central stem. The leaves of a great many plants slope inward and downward, directing the water falling upon them to the central stem and roots. Indian corn and cabbage are good examples of this kind.

Nature always fits a plant to meet the conditions of its surroundings; so, it must be that some plants need most water for the central roots, and others need it for the outer ones.

Looking up into almost any tree, one will find few leaves around the central stem and branches, but very many on the outer twigs. The reason for this is the same as in the other cases given-the struggle for light and air. If many leaves were to grow within the circle of the outer ones, so much light would be shut out that but little work could be done by them. This mode of leaf position is particularly noticeable in the elm, the leaves of this tree not only being on the outermost twigs, but the greatest number on the topmost branches, giving that tree its decidedly characteristic shape.

THE NUMBER AND PARTS OF LEAVES.

Another feature of leaves which might be classed under arrangement is that of numbers. Each plant requires a certain amount of work to be done for its development, and it takes a certain amount 


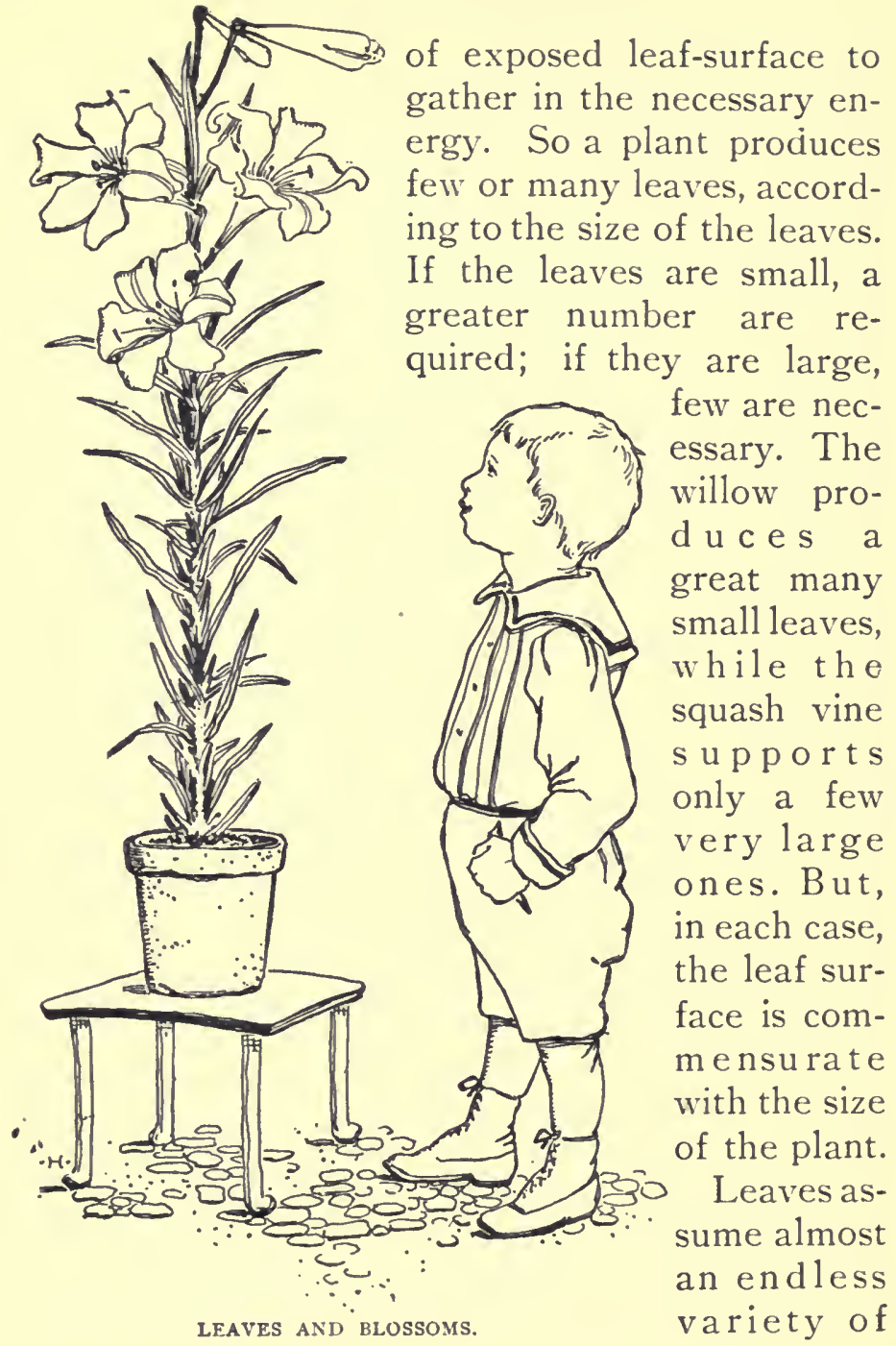


shapes, but each shape, no doubt, is for some definite purpose. A leaf may have three parts-blade, leafstalk, and stipules. The stipules are small leaflike appendages at the base of the leafstalk. In a great many cases there are no stipules, the leaf consisting of blade and petiole only. In a great many more cases, the petiole and stipules are both wanting, the leaf consisting of blade only. The blade is the essential part of the leaf, and where the leafstalk is wanting, the blade is attached directly to the stem at one end, or, sometimes, the stem goes right through it, either at the center or at some other point. The petiole is a device for carrying the leaf into free air and light, so its length varies according to circumstances. Some leaves turn very easily upon their petioles, fluttering with the slightest breeze, and thus secure every stray molecule, of passing carbonic acid gas.

Leaf blades are either entire, or divided into parts. A leaf that is smooth around its edge is called a simple leaf. With some leaves, the margin is indented very much like the teeth of a saw. Others have still deeper notches, forming what is known as a lobed leaf. In another class of leaves, the divisions extend clear to the midrib, forming a compound leaf.

Often a compound leaf is mistaken for several simple leaves, but it can be distinguished in two ways. That part which falls off in the autumn is the whole leaf, and new buds for the next year's 
growth develop at the base of the leafstalk. The divisions, or leaflets, of a compound leaf do not, in falling, separate from the main stem, which is, in fact, the midrib; and no buds develop at the bases of the petioles of the leaflets.

Examples of compound leaves are the walnut, rose, and locust. Some compound leaves have their leaflets compound. These leaves are called doubly compound. Some are even trebly compound. Examples of lobed leaves are the oak, - maple, and water-melon vine; of toothed leaves, the elm, willow, and peach; of simple leaves, or entire, smooth margins, Indian corn, redbud, and plantain.

Leaves are built upon a framework of veins. Generally, there is one large vein in the middle of the leaf, called the midvein, and many small veins issue from it, making it resemble a feather. In others there is a network of small veins on each side of the midvein. The veins in many leaves all radiate from one point, which is the point of attachment of the petiole to the blade, providing there is a petiole present. A good example of the last is the common garden nasturtium.

Compound leaves take their shapes from the style of venation. If the small veins spring out along the midvein, the result is a compound leaf like that of the sumac or tomato; but if they all radiate from one point, the result is a compound leaf like that of the chestnut or clover. 
Much could be said about divided leaves, for the varieties are endless, but the common principle underlying all is that the more divisions a leaf has, the more surface there is exposed compared with the mass. Some plants grow, or their ancestors

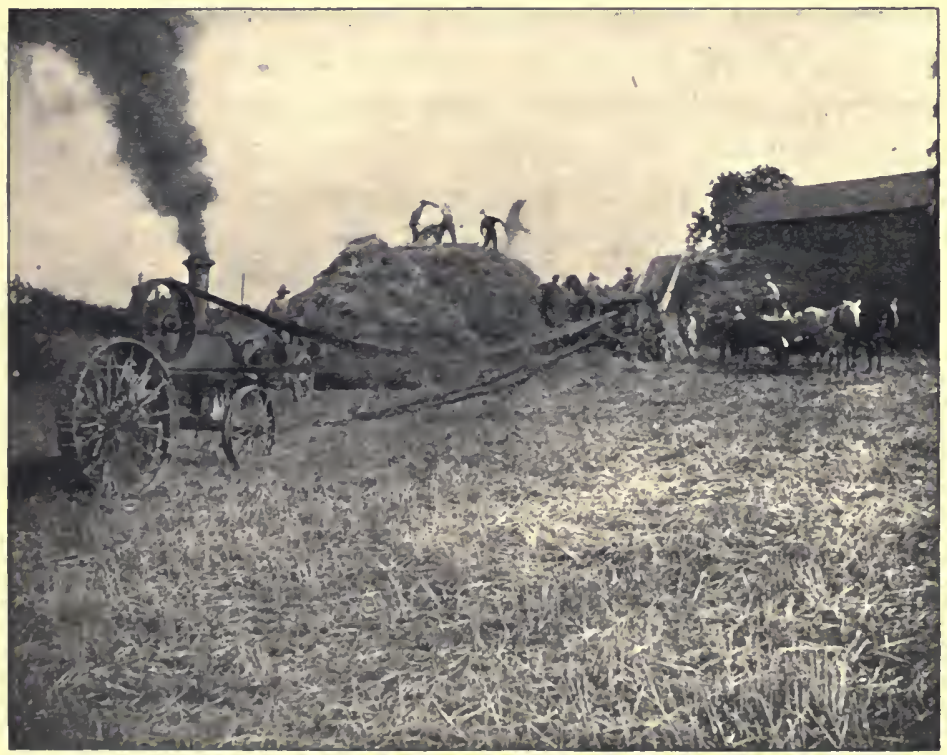

THRESHING WHEAT.

have grown, in locations where there was so much competition among the leaves for air and light that a leaf with an entire margin could not secure enough food and energy to carry on the necessary work, so it had to divide its blade to accomplish the rẹsult. 
The author has found on sassafras, and on blackberry vines, in very shaded locations, no less than twenty different kinds of leaves, varying from simple through lobed to compound, on a single, individual plant. Thus it has come about, through struggle for existence, that plants change their structure and habits to make a living for themselves and to propagate their kind. It is much the same with lower animals and with human beings. Men will do all kinds of work, and endure great hardships, in order to provide for themselves and their children.

\section{STORING OF FOOD IN PLANTS.}

Under the discussion of the work done by leaves, it was stated that they take gases from the air, and mineral substances from the earth, and manufacture them into organized substances. A part of these substances goes to build up the plant structure itself, but in the late stages of plant growth, the best and richest materials are stored away in different parts of the plant for the beginning of the next year's growth, or for the starting of new plants. When a new plant starts into life, or when the same plant renews its life and growth after the cessation of activities during winter, there must be something for it to start on before leaves are put forth to gather in and make food.

With plants that do not annually die down to the ground, new buds can be found at the base of the 
leaf stalks in autumn which will give rise to new leaves the next year. These buds are stored with food. The food is built into them during the summer, and an additional supply is drawn from the old leaves just before they fall off for the winter. Some food, also, for the starting of new leaves is, no doubt, stored at other places in the plant body, either in the cells or among them; and, no doubt, a large quantity in the roots; for, when sap begins to flow in spring, it contains rich food. The sugar maple, and hickory are good examples of trees in which much sugar is present in the first flow of sap. In the hickory, there is such a large proportion of sugar that it exudes as a thick syrup, with the sweetness and consistency of honey. This food goes to start new leaves before they are able to work for themselves; but as soon as the store of food is used up, and they have unfolded to the air and light, mineral substances rise with the sap and the building process begins.

Plants that die down to the ground annually, and renew their growth from bulbs, tubers, and underground stems, store up food in these to be kept over winter, or during a dry season; and from these the new plants draw supplies until they are large enough to have sufficient leaf and root surface started to take care of themselves without any help. Examples of these are bulbs of lilies and onions, tubers of potatoes and artichokes, and underground stems of Solomon's seal 'and black- 
berry vines. Some of the bulbs and tubers are rich in the starchy foods.

Flowering plants, in their native state, bear seeds from which new plants start. Those, of course, which have bulbs, tubers, and underground stems, have a double advantage-for they start their young from seeds as well as from these underground parts. Seeds are storehouses for food of the highest type.

The final total energy of a plant goes for the production of seeds. It labors day in and day out, from germination to maturity, to gather and organize rich materials to be stored in its seeds for the production of new generations. Annuals exhaust all their energy and die as soon as their seeds are matured. Most of them leave dry, withered stalks for an early and rapid decay; because, practically, all nutritious substances from roóts and branches were withdrawn at, and before death, for the final and complete development of the seeds.

\section{THE IMPORTANCE OF PERFECT SEEDS.}

Of all the parts of a plant that contain food, seeds are the richest with respect to their size. There is very little water in them-the food is consolidated and rich.

There is very little substance but water taken from the soil during the early growth of plants, but when the seeds begin to form and rtpen, the richest ingredients are called for. It is then that 
the quality of the soil is tested; and, if it be poor, one heavy crop of seeds will so exhaust it that a crop of the same kind the succeeding year will not be worth the harvesting.

Weeds, of course, rob the soil for their seeds; but, since they either fall upon the ground or are

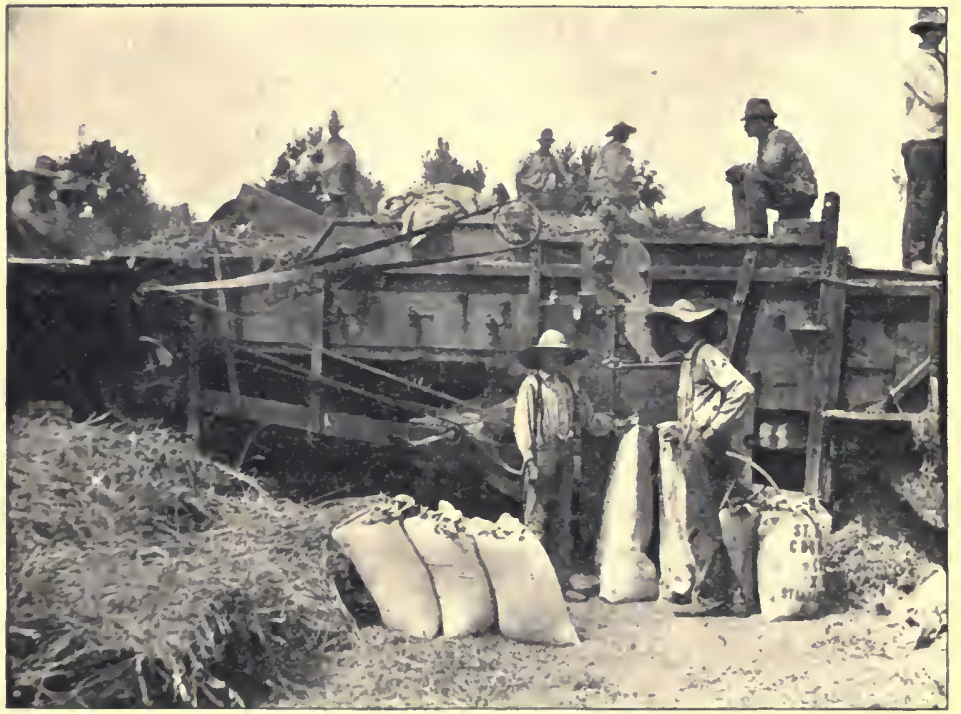

MEASURING WHEAT AT THF THRASHER.

plowed under, the rich substances they take from the soil are returned to it again. Useful, seedbearing crops are usually taken away from the soil on which they were grown, little or none of their substance ever being returned. In this way soil, whether it be rich or poor, will, sooner or later, 
lose its vitality and refuse to yield harvests to the cultivator. When a harvest of seeds is taken from a field, its equivalent in some form should be returned if the quality of the soil is to be retained.

The composition of seeds and other parts of plants will be taken up in another chapter, but let it be noticed here, that seeds, together with bulbs and tubers, are the great sources from which human beings derive food. Without them, life as it now is would be impossible.

If it can be said that plants desire, it is not their desire to produce seeds and tubers for man to use, but for the propagation of their kind. 'In fact, they take all precaution to prevent their being eaten;- - the hard shells of nuts, the thorny covering of some, the repellant taste of the outer coats of others, and a hundred other devices making them difficult to secure. Plants, having no particular device for the protection of their seeds against animals, produce so many to each plant that a few always escape and find their way to suitable soil for germination.

Man, with machinery, does what he likes with plants. Those kinds which he finds rich in starch, sugar, oils, or albumen, he cultivates to the exclusion of other plants. Under cultivation, there is no longer a struggle for existence-the farmer with his machinery protects and aids them so much, that plants can use their entire energy in producing more food. Thus plants, which in the wild state 
produced only a few small seeds or bulbs, in a cultivated 'state produce many large ones. Seeds whose coverings offer almost complete resistance to the teeth of animals, offer none to the teeth of modern machinery, and are converted into numerous kinds of wholesome and nutritious foods.

INDIVIDUAL PLANTS-INDIAN CORN.

Indian Corn, or Maize, belongs to the family of grasses. This can easily be seen by a close observation of the leaves and stalk. It will be found that the veins run parallel, and that the stalk is jointed like that of grass. The stalk is somewhat tubular, the outer body being hard and tough, giving it great strength. The inside is made up of a soft, cellular, pithy mass with parallel, fibrous strings, running lengthwise from joint to joint, similar to the veins in the leaves.

The corn plant grows from six to fifteen feet high. It is from a light or yellowish green to a dark green in color during the growing season, the composition of the soil and the amount of rain-fall making the difference in color. When the ripening of the grain begins, and the food stuffs are withdrawn from the stalks and leaves, the color changes to yellow and brown, with sometimes a tinge of orange and red.

The plant has but one central shaft, there being no branches. The leaves are arranged alternately 
on the stem, and are attached to it directly, without any petioles. They are long and ribbon-like, with a very heavy midrib through the center from the base to the tip. They arch upward in a graceful curve, the inner part sloping downward to

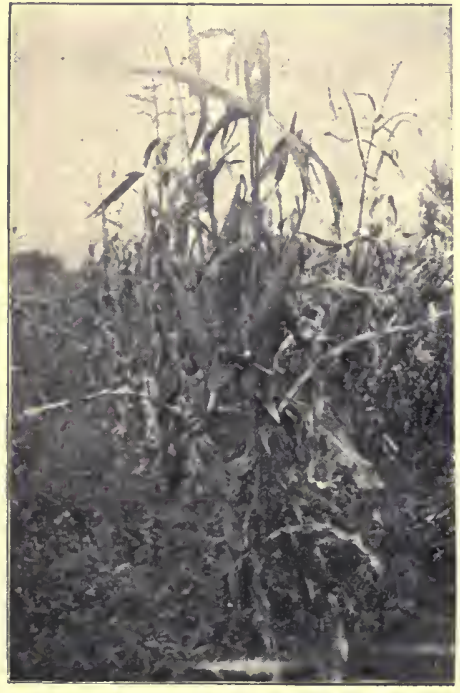

CORN GROWING. the central shaft, and the outer part sloping downward and away from it. The attachment around the base is such as to give them a trough, so that part of the rainfall is carried to the stalk to find its way to the roots of the plant, and the rest is directed away. The leaves wave under the influence of the wind in a plume-like fashion, and the plant as a 'whole bends and nods with every passing breeze.

The blossom of corn is divided into two parts, one part being at the very top of the plant, and the other part about half way down the stalk. The part of the blossom at the top is the pollen-bearing or staminate part, and the part down on the 
stalk is the pollen-receiving, or pistillate part. Sometimes there are two, three, or more of the latter, but generally only one. They are called the ears of corn, while the part at the top is called the tassel.

The tassel bears the pollen, which falls upon the ear or is carried to it by the wind. The ripened ear has a long, cylindrical, rough, woody core called the cob. During the early stages of the ear, the cob is green and soft; connected with it in rows are long, white, or green threads, commonly called silks (but in reality the pistils of the blossom), which extend several inches beyond the outer end of the cob. These silks, or pistils, receive the falling pollen and bring it back to their points of attachment to the cob, at which places it produces the seeds, or grains, of corn. As soon as the grains are mature, the silks die and turn brown.

The whole ear of corn is covered completely by layers of tightly-fitting leaves, similar to the leaves of the plant. This part is called the husk and must be removed before the grains can be shelled from the cob. The husk is a protection for the grains against the weather and the attacks of animals. There is a similar covering around grains of wheat and oats, but in those cereals there is a separate husk for each seed.

PLANTING AND HARVESTING CORN.

Indian corn, in the central states, is usually planted in May and June, though sometimes as 


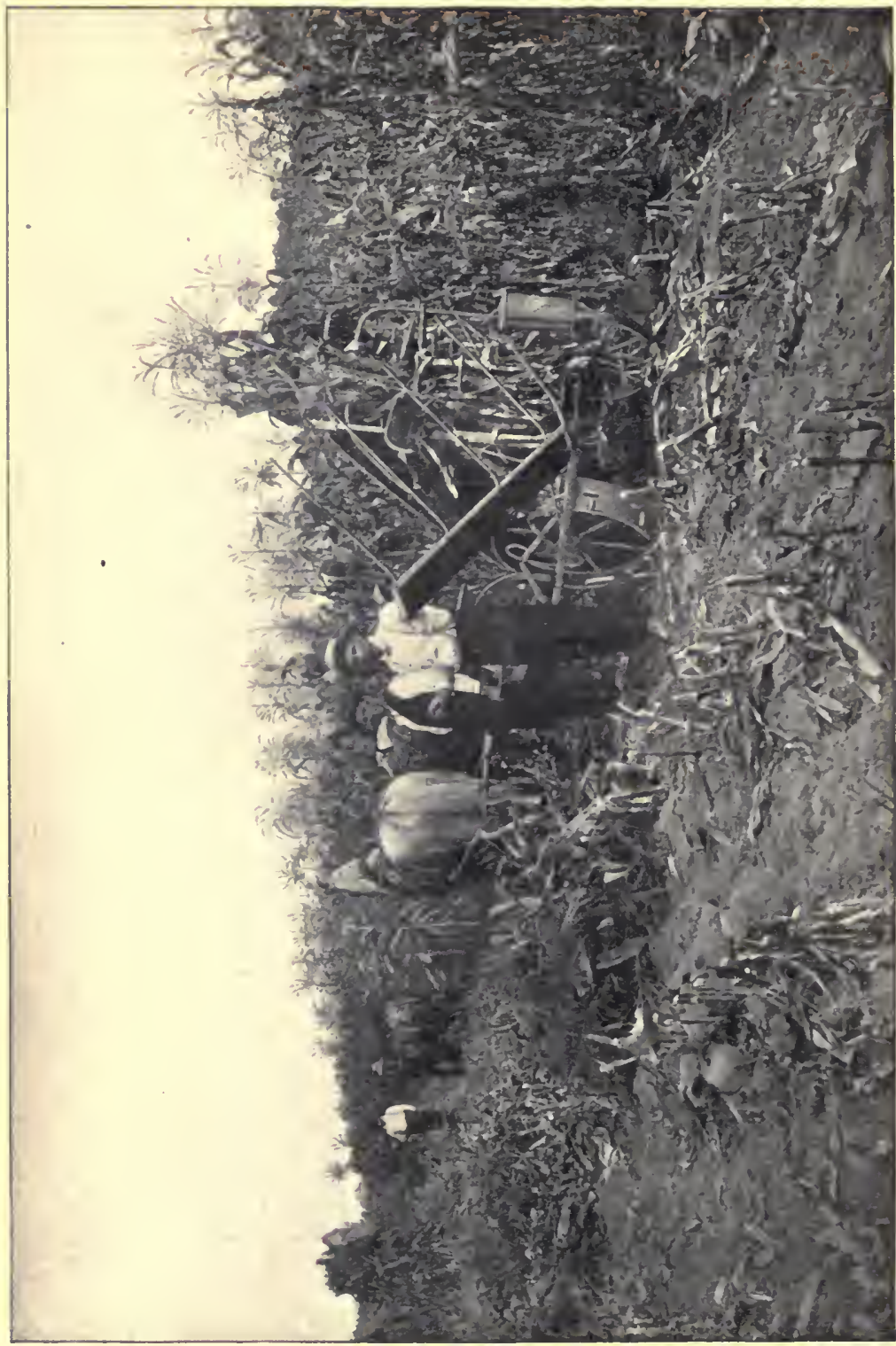

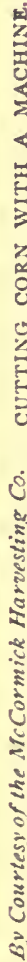


early as April, and as late as July. After the ground is plowed and harrowed, it is planted in rows about four feet apart, the plants being from one to two feet apart in the row. It is planted with corn drills which plant one or two rows at a time, according to the style of the drill. Those which plant two rows at a time are drawn by two horses, and those which plant only one require but one horse.

The seeds germinate in a few days, sending up a single blade, as all grasses do, the seed consisting of but one cotyledon. As it grows upward, it puts out leaves first on one side then on the other, so that there are two rows of leaves up the stalk on opposite sides; but, as has been said before, these are arranged alternately on the stem. Last of all the tassel and ears appear; and as soon as the grains in the ear are mature the whole plant dies, from the tassel to the lowest roots.

Most species of the grass family are provided with bulbs or underground stems, and spring up each season from them; but the corn plant has no such underground parts. New corn plants germinate from seeds only. It is the same with wheat and oats. Corn, however, has a species of roots rarely found in other cultivated plants. They are called aerial roots. They grow out in circles near the base of the stalk, and are called brace-roots because they brace the stalk of corn against the force of the wind. They appear just before the plant is 
full grown, because, with the added weight of the heavy ear, there is then the most need of support.

Weeds soon spring up in a corn field on account of the plants being so far apart; so incessant cultivation is necessary to destroy them. Cultivation not only keeps down the weeds, but also keeps the soil in a condition for holding moisture. Corn, of all plants, requires a great amount of water for its growth and development. It should be plowed four or five times during a season, best while the plants are small, so that the roots may not be interfered with. After the plants are large enough to completely shade the ground, further cultivation is unnecessary; for the shade not only prevents weeds from growing, but also keeps in check a too rapid evaporation of soil moisture.

Corn is harvested, or gathered, in late autumn, or at any time during the winter. Some husk it in the field, and others cut and gather it, husk and all, leaving the husking till the corn is needed for the market or for feeding. The leaves of corn being of the same nature as hay, the stalks are sometimes cut just before frost and made into shocks in the field or placed in barns. In this form it is known as fodder, and makes a good, rough feed for cattle and horses during autumn and winter. The stalks are not eaten, being too tough and coarse. Owing to its bulky nature, corn fodder is never shipped away to market, but is fed on the farm where it is raised. 
The grains, or seeds, of corn, are the most useful part of the plant. They are rich in starchy matter, and, for that reason, are used largely in fattening animals for market. Corn being rich in starch, and that being easily converted into similar organic compounds, is manufactured into many different things. The most common are corn-starch, syrup, and alcohol. One firm has succeeded in producing nearly fifty different and distinct substances from corn, among them being a substitute for India rubber, which is almost as good as the genuine article from the India rubber tree.

It would be almost an endless task to describe all the virtues of this wonderful plant, so the high tribute paid it by the poet Longfellow is given below:-

Day by day did Hiawatha

Go to wait and watch beside it;

Kept the dark mold soft above it,

Kept it clean from weeds and insects,

Drove away, with scoffs and shoutings,

Kagahgee, the king of ravens.

Till at length a small green feather

From the earth shot slowly upward,

Then another and another,

And before the summer ended

Stood the maize in all its beauty

With its shining robes above it,

And its long, soft, yellow tresses;

And in rapture Hia watha

Cried aloud, "It is Mondamin!

Yes, the friend of man, Mondamin!"

Then he called to old Nokomis,

And Iagoo, the great boaster, 
Showed them where the maize was growing,

Told them of his wondrous vision,

Of his wrestling and his triumph,

Of this new gift to the nations,

Which should be their food forever.

And still later, when in Autumn

Changed the long, green leaves to yellow,

And the soft and juicy kernels

Grew like wampum hard and yellow

Then the ripened ears he gathered,

Stripped the withered leaves from off them,

As he once had stripped the wrestler,

Gave the first feast of Mondamin,

And made known unto his people

This new gift of the Great Spirit.

\section{THE POTATO.}

The potato plant belongs to the nightshades, a family of plants containing poisonous principles. It is a near cousin to the common garden tomato. The potato is a native of Mexico and Central America, but has been introduced into and is now cultivated in many different countries and climates.

The tuber, or swollen portion of the underground stem, is the part of the plant used for food. In its native state, the tuber of the potato is no larger than the plum or cherry, but by cultivation and selection it has increased to its present large dimensions.

Scattered over the tuber are a number of buds, commonly called eyes, and from these buds new plants grow.

In planting potatoes, the large ones are cut into 
several pieces, but each piece must contain an eye. Since the tubers grow and expand in the ground, they require a loose soil for a good crop.

Potatoes are planted in rows about four feet apart so as to admit of cultivation; and the hills in each row are from two to three feet apart. The time for planting is from the final disappearance of frost from the ground until July, according to the variety. The early varieties mature, in central and northern United States, about the first of July; and the late varieties in September and October.

The plant bears blossoms, and grows from two to four feet high, with a tendency to vine, or run along the ground; hence, the term potato vine. As soon as the blossoming is fully over, all of the nutritious substances of the upper part of the plant are withdrawn and stored in the tubers, the vines quickly withering till scarcely any trace of them can be found a few weeks later. Corn or sunflower stalks have so much substance left in them that they exist a year or more after maturing; but not so with the potato vine. What little material is left in it soon decomposes and the products return to the air and soil.

Like all tubers and bulbs, potatoes are composed largely of water, and must be kept in a temperature above freezing, for freezing renders them unfit for use as food. Corn, and most seeds, contain such a small percentage of water that freezing does not affect them. Bulbs and tubers, however, can be 
frozen solid without impairing their germinating powers or food properties, providing they be left in the ground till after thawing out. The soil seems to have virtue of such a nature as to withdraw the frost so gradually, and in such a manner as to revivify them. If this were not so, a great many of the most beautiful of wild plants would be destroyed by the deep soil-frosts of severe cold winters.

The usual manner of keeping potatoes during winter is to place them in cellars or bins, or to cover them in the field in large heaps, first with a layer of straw, then with earth deep enough to keep out frost and shed rain. This is claimed to be one of the best ways of storing them.

Potatoes are classed with the starchy foods, although less than one-fourth of their composition is starch. Three-fourths of the potato is water; so that there is but one-fourth solid food.

Besides being used very extensively for food, the starch of the tuber is made into dextrin, grape sugar, and alcohol.

The skin of the potato contains a poison, but this is destroyed by steaming or boiling.

\section{BEANS AND PEAS.}

There are many varieties of beans and peas, and, although they differ to some extent, yet they are very similar in their nature and growth. The most prominent marking of the large order to which 
these plants belong, is the seed pod. The bean or pea pod is in reality a transformed leaf. When a pod is broken open, laid out flat, and the seeds taken out, it resembles a leaf very much. The long, tough fiber along the back of the pod corresponds to the mid-vein of the leaf, and the line along the front of the pod is the union of its two margins. The fibers of green pods are called strings and must be removed before the pods are cooked for food.

Beans and peas are good examples of the twocotyledonous plants. That is, the seeds are in two parts, and in germination these two halves are lifted into the air above the ground to act both as leaves and a storehouse of supply, till the plants have enough roots and leaves to make a living for themselves. It will be noticed that the two cotyledons, or halves of the seed, turn green as soon as they reach the light and air, which means that they are endowed with chlorophyl and can manufacture protoplasm as well as supply it ready made. As soon as true leaves are developed, the cotyledons are absorbed by the plant and fall into disuse.

Beans and peas grow rapidly, requiring but from six to ten weeks for growth and maturity; hence, they are planted from early spring till the middle of summer. They are annual plants and die away, root and stalk, as soon as the seeds ripen.

The seeds germinate and spring up in a day or two when planted in warm, moist soil. They need but a thin covering of earth for germination. 
When covered too deeply, they decay in the earth and no crop results. They are planted either in rows for cultivation or sown thickly, as grass or wheat, so as to take full possession of the soil, and grow about as well in one way as the other.

The crop is gathered and shelled from the pod by hand, or cut with a mowing machine, and threshed with a separator similar to the one used for wheat and oats.

Some beans are picked before the seeds are mature, the tender pods being cooked and used for food. In this green form they are known as string-beans.

There are a great many kinds of beans and peas. Some are used as food for human beings and other kinds for live stock. The latter kind are fed very much as hay is-cattle, horses, and pigs eating them. They eat not only the seeds, but pods and leaves also. Beans and peas are rich in starch and albuminoids, the former producing fat, and the latter flesh, or lean meat; so that they are desirable in fattening animals for market.

All plants of this order not only produce seeds rich in albumen, or nitrogenous food, but they also have the power of extracting free nitrogen from the air and fixing it by means of their roots as nitrates in the soil, from whence other plants can draw supplies. They are able to do this through nitrifying germs growing in little knobs on their roots. For this reason such plants are considered beneficial to the soil and are often grown and plowed under as fertilizers. 


\section{CHAPTER III.}

\section{TREES.}

The study of trees important. Planting groves. Trees afford beauty, timber, and protection. Individual trees:-the elm, the sugar maple, the oak, the cottonwood, the hickory.

At first thought it seems unnecessary to take up time under the subject of agriculture for the study of trees, but when viewed in its true and broadest sense, the study of trees commands a place of no small importance. It is a part of farm life that has generally been too much neglected, but which soon must become a serious study.

When this country was first settled, it had the most magnificent forest areas of any part of the world. It was a matter of necessity, of course, to clear away a great part of these forests for timber and agricultural purposes. The latter half of the past century has witnessed not only a wholesale destruction of vast areas of forests, but also a waste of the timber. This has continued at such a rate that good timber is fast becoming very scarce. The loss of timber is not all the damage. It is a well know fact that forests, with the deeply penetrating roots, and gigantic leaf surface for the evaporation of water, are great regulators of rain- 
fall. They regulate the surrounding atmosphere by the enormous amount of water evaporated by their leaves, and by the absorption of heat necessary for tree growth.

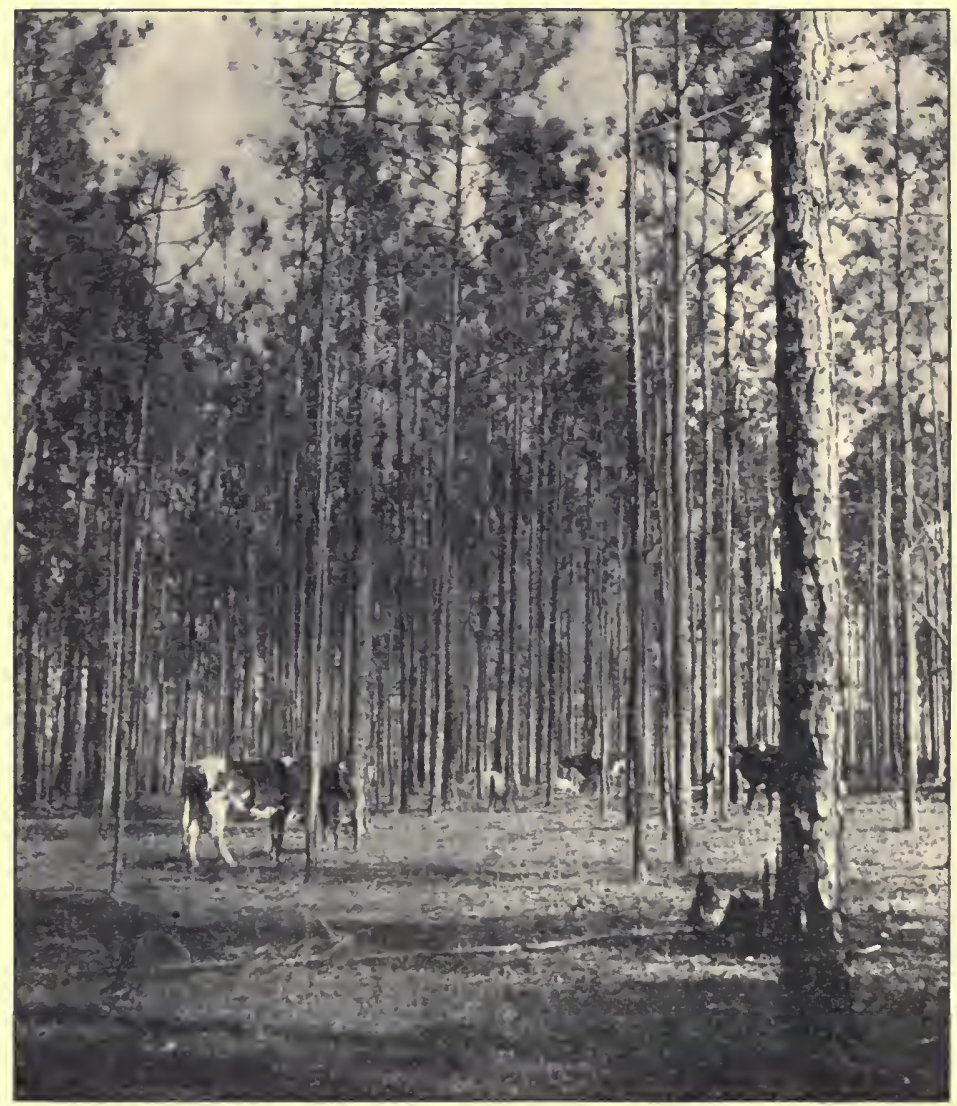


The water evaporated by leaves keeps the air saturated. This moisture aids in the precipitation of rain. When, however, there are few trees to supply atmospheric moisture-since rainfall is dependent upon additional moisture carried by winds from the seas, long dry periods are likely to be experienced in certain sections during summer when rain is most needed.

A forest gives out much moisture to the air by leaf evaporation, and holds back the water on the forest floor, so that it is given off gradually. This is an ideal condition. It is not the great amount of water falling upon the ground at one time that does most good, but the constant supply. A forest holds back the water in two ways: by shading the ground so that little evaporation takes place, and by retaining it among fallen dead and decaying leaves and branches. The latter not only has a tendency to produce frequent summer rains, but also prevents the rapid rushing away of heavy rains to cause floods.

Trees are great barriers against scorching, hot winds in summer, and against strong, destructive winds coming at any time of the year. In the western prairie states many groves have been planted purely as wind-breaks for farm buildings. They have proved to be very efficient in that respect. Besides, the people there are now able to use many of the trees for fucl and timber because of the necessary thinning as the trees grow in size. 
THE PLANTING OF GROVES.

The planting of groves must now be taken up in nearly all sections of the United States to supply the deficiency caused by the wanton and ignorant destruction of trees which has taken place. Grove or forest planting will be a general good to the country at large, and a special good to those who plant them. It will be capital well invested.

A cultivated forest, to be profitable, should be planted and tended much the same as a field of corn. The ground should be plowed and harrowed late in autumn, and the seeds, or nuts, planted in rows from three to four feet apart so as to admit of cultivation for the first few years. The seeds should be planted in the fall of the year, because most kinds require the moisture and frosts of winter to render them capable of sprouting in the spring. This is nature's way of planting trees.

In planting a few acres of trees on a farm, the kinds should be considered. It is always well to have a variety, but the greatest numbers should be those that have the greatest value, both for their wood and their fruit. A few years after planting the thinning out of every alternate tree is necessary, and a few years after that still more is required. The first thinnings, of course, are small, but they have a market value, and can be used in various ways. For instance, the first thinnings of hickories are used as walking sticks, and always 
command a good price. The later thinningswhen the trees have attained a diameter of an inch or more-can be used for almost numberless purposes, both on the farm and in the factory.

Such a cultivated grove will require some ground, but the poorest of land can be used. Land on which nothing else will grow will produce a good growth of trees with a little care. After the trees have attained some size, the field can be used as a pasture for live stock. Not much grass will grow on the ground, but the shade is of benefit during the hot summer months, and they afford protection against cold winds in winter. Pigs, especially, do well when raised on wood land. They not only like the shade, but find a considerable amount of food beneath and among the fallen leaves. They eat acorns very greedily.

TREES AFFORD BEAUTY, TIMBER, AND PROTECTION.

Besides the monetary value of a forest, it adds to the beauty of a farm. A solitary ornamental, shade, or fruit tree, is beautiful; but a forest or a grove has a charm which surpasses them all. There are few things more beautiful and more harmonious. A stroll through the woods in autumn, winter, spring, or summer is one of the most pleasant pastimes that can be taken by one who loves nature.

Trees, whether solitary, in groups, or in a forest, impress us with their size, endurance, symmetry, 
and beauty. When other plants have yielded to frost and cold, and died away, trees stand proud and sublime against the strongest blasts of winter, raising into the air their trunks and branches with

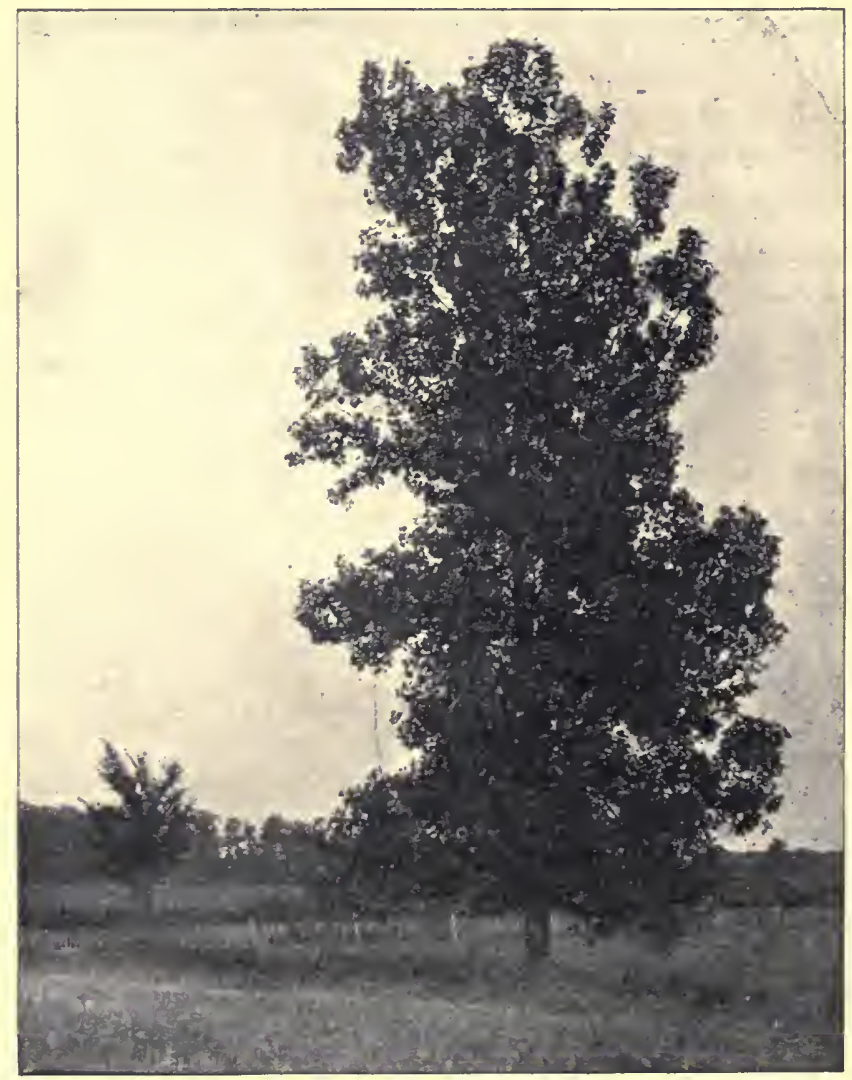

COTTONWOOD TREE. OAK FOREST IN THE DISTANCE. 
mantles of snow and ice. Then comes the renewing of life-activities in spring, with the swelling and bursting of buids, and the display of the softest tints and colors. Summer brings its millions of leaves, its welcome shade, and its subdued colors. Most glorious of all are the radiant foliage colorings of autumn, telling that the trees have furnished their season's work, and are ready for the long rest of winter.

A small tract of woodland on a farm presents another advantage, and that is the number of birds that will be attracted by it. Birds love the shelter of trees for roosting and nesting, and will seek them wherever they can be found.

During the nesting and breeding season, the parent birds supply their young with food from the immediate surroundings. The food carried to young birds consists mainly of soft-bodied insects, such as grubs and caterpillars, and these generally are the forms most destructive to crops.

Birds, when undisturbed, as they would be in a standing grove of trees, love to build year after year in the same place. So, as the trees grow, the farm would have a constant natural exterminator at work against the enormous inroads of insects, and stronger and more sure than the best artificial means.

Besides the good they do in keeping down the number of injurious insects, birds add to the cheerfulness and beauty of every rural scene, with their 
joyful songs, gentle social influences, and beautiful plumage.

\section{INDIVIDUAL TREES.}

Since the subject of trees has become such an important study, it is well to know something about individual trees, so that their names and characteristics may become more familiar.

It is no easy matter to say what trees are of the most importance, because that depends largely upon taste and the uses for which they are planted. A few of the common trees of central United States will be given here.

\section{THE ELM.}

The Elm Tree family is a large one, but its members have so many points in common that a description of one will give a tolerably clear image of all.

The common American elm may be taken as a type. This elm tree grows to a height of from fifty to more than one hundred feet. The bark is rough, and dark gray in color. The wood is reddish brown, and rather soft in its nature, but difficult to split on account of its interlacing fibers. For this reason the young trees are used for the hubs of wagon and carriage wheels.

The elm is one of the easiest trees to identify because of its shape. It rises as one central shaft for a considerable distance, then divides into 


\section{TREES.}

several principal branches, and these again into smaller ones-all taking a decided upward direction, making sharp angles with the main trunk and with each ot her. Very few branches assume a horizontal or drooping position, except the outer lowest ones. This upward tendency of all the branches gives the tree the general shape of a feather duster.

All the branches of an elm tree are graceful in form throughout. They are not as pliant and tender as those of the willow, nor as rugged as those of the oak, but possess that unassuming grace so pleasing to the eye.

Owing to the upward tendency of the

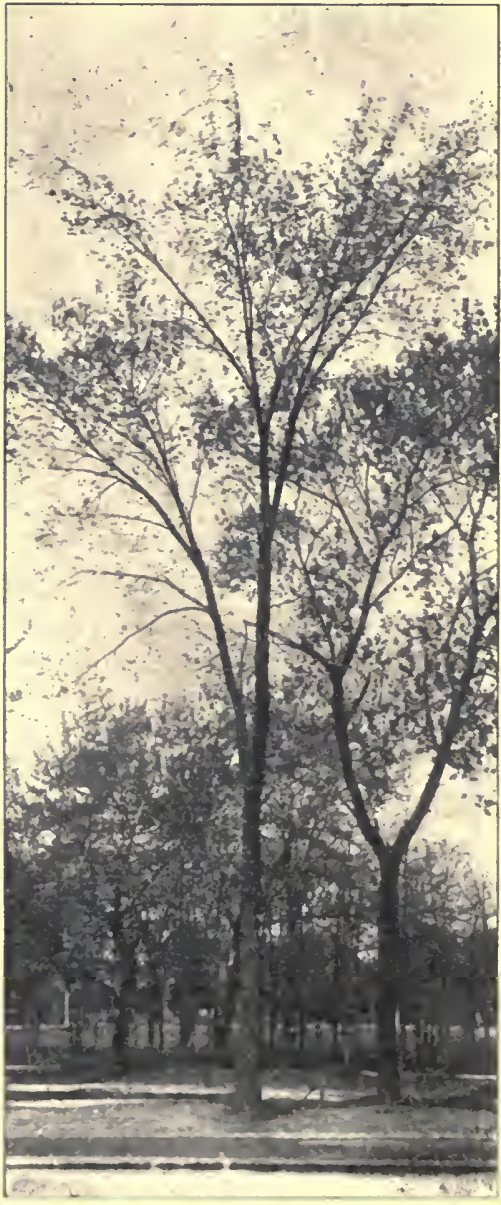

THE ELM, BOX ELDER TO THE RIGHT. 
branches, most of the foliage is at the very top of the tree. In very few cases are there leaves at any other place. This is one of the features by means of which the tree can be so easily distinguished.

The leaves of the elm are arranged alternately, are rather rough on both sides, and have a notched or saw-toothed margin. The leaf can always be told from the fact that one side is always a little larger than the other. Strong side-ribs spring out all along the midrib, terminating in the margin. The leaf, as a whole, is strong and firm.

The blossoms appear early in spring, and the seeds mature before the leaves are fully developed. A single tree bears an almost countless number of seeds, from which young elms readily grow.

The roots of the elm are long and fibrous. They do not strike very deeply into the ground, but run near the surface in great numbers. Since they grow so near the surface and take up so much moisture, very little other vegetation can thrive near the tree; hence they require much room. With old trees, the large roots strike out above the ground for a few feet, giving the lower part of the trunk a very uneven appearance.

The American elm should be planted for its beauty and shade. It is easy to start and very hardy, growing vigorously for nearly a hundred years. It is seldom attacked by insects; and its branches, though graceful and pliant, are so tough 
that the strongest blasts seldom break them. It retains its symmetry of form till old age.

THE SUGAR MAPLE.

The sugar, or hard Maple extends from New England to the West Central States. It grows more slowly than some of the softer varieties, but finally attains a very large size.

When growing by itself in an open space, the branches and leaves come out low down on the stem. The top of the tree in such open locations is generally oval in shape. In a crowded forest, however, the main stem often rises forty or fifty feet without a single branch.

The bark of the sugar maple is light gray in color, and is smooth on young trees, but rough on older ones.

The wood is very hard, strong, fine-grained, compact, and capable of taking a high polish. It is one of the most useful of all woods, especially for tools, furniture, and floors. It is especially made use of for floors, owing to its fine grain and great wearing qualities. The wood is also valuable for fuel, making a hot, cheerful blaze nearly equal to that of hickory.

The leaves of the tree are among the most beautiful of all leaves. They are arranged opposite on the stem, and have long, slender petioles. The simple leaf is divided into five principal lobes and 
several smaller sub-divisions, each ending in a sharp point. The veins radiate from the base of the leaf blade, giving it the palmate form. The autumn colorings of maple leaves are most glorious. They flash under October skies in red, crimson, orange, and yellow.

Maples blossom early, and the seeds ripen before the middle of summer. The seeds are borne at the end of long, pendulous foot-stalks, diverging into two wings forming what is known as maple keys. One of the capsules is usually empty, probably for the reason that two seeds cannot germinate at the same spot without crowding each other. By means of the two wings the seeds are carried by the wind and planted in new soil. It is easy to grow maples from the seed.

One of the most noted things about the sugar maple is the sweetness of its sap-from which maple syrup and maple sugar are made. The sap is drawn from the trees in very early spring, before the leaves begin to grow. Boring into the tree for sap beyond question weakens it to some extent, but the injury is so slight that the effect is seldom noticed, even though repeated for twenty or thirty consecutive years.

On the whole, the sugar maple is a very beautiful and useful tree and will stand for generations in full vigor. No farm should be without a grove of sugar maples. 
OAKS.

There are a dozen or more species of the Oak family, but they may all be classed roughly into two groups; namely, the white oak group and the red oak group. The white oak group matures its fruit in one year, and has rounded, lobed leaves; the red oak group has sharp-pointed, lobed leaves and requires two years for the ripening of its fruit.

The oak stands as an emblem of strength, fortitude, and endurance. There is nothing tender or pliant in its make-up. It is the embodiment of massiveness from its large, anchoring roots to the tips of its branches. Some trees bend or sway under a heavy load of ice and snow or the force of a strong wind, but not so with the oak. It resists everything with its own great strength. For this reason it has a wide range, being able to grow in almost any situation. It is a native of both Europe and America. It will grow in the sheltered valley or upon the unprotected mountain side, and thrive almost equally well in both places.

Oaks grow to be very old. They are about twenty years old before they produce acorns, and a century or more before they are fully grown. There are oaks in England nearly a thousand years old, and some in the United States several hundred.

A description of the white oak will give a fair notion of the whole family. 
The white oak is so called because of its lightcolored bark. The bark is not pure white, but light gray'. The bark of the white oak, as well as of all oaks, contains a large amount of tannic acid which is used in tanning leather. Enormous quantities of oak bark are used for this purpose.

The quality of strength so characteristic of the oak family is accentuated in the white oak. The trunk is large and strong, the branches are gnaried and massive, striking out boldly from the main stem nearly at right angles, while the great, bulging roots at its base strike strongly and deeply into the earth, giving it a foothold that defies the wildest storm.

The white oak blossoms in early summer and ripens its acorns before the autumn frosts of the same season. The acorns are readily eaten by many animals, and are quite nutritious. They may even be eaten by human beings. Young white oak trees are best secured by planting acorns, because the trees do not bear transplanting well owing to the downward tendency of their roots.

Young white oak leaves unfold slowly from the buds, being soft in texture and pink in color. They are green during the summer, and turn red in autumn.

The wood of the white oak has made it famous the world over. It is beyond question the strongest of woods, and is used for numberless purposes where strength is required. The strong timbers in 
ships, houses, cars, bridges, and large machinery are nearly all made of white oak. It is also used to a large extent in making strong casks, handles for tools, frame work for carriages and wagons, and different parts of small machinery. There has been such a demand for it in so many lines that it will soon disappear if replanting is not vigorously begun.

It is also one of the most beautiful and substantial woods for furniture and inside finish, taking the highest polish and giving an air of strength and solidity so desirable in such work. Some of the red oak group are equal to, or even better than the white oak, for the last named purposes, because of the darker color of the wood.

Oak ranks among the best of hard woods for fuel. It burns with a hot, cheerful blaze and lasts for a long time. The early settlers of the Mississippi valley used it not only for fuel, but they split it into rails for fencing, cut it into posts, and built it into frames of houses and barns. The white oak stands the effect of outdoor, wet weather better than any of the other species, save, perhaps, the post oak, which is its closest relative.

May the time soon come when every farm can boast of its grove of young oaks, to be handed down as a noble heritage to future generations. -

THE COTTONWOOD.

The Cottonwood belongs to the poplar family. They all have soft wood and are very rapid grow. 
ers. The wood is so soft and difficult to work that the trees have been considered worthless till of late. It has recently been discovered that the wood has a high commercial value, and can be used for many purposes. It is now used very extensively for making paper.

Its rapid growth and hardiness also make it a favorite with those who wish to have a forest or grove in a few years. An investment in a grove of cottonwood trees will give quick returns. The trees grow readily in almost any part of the United States. They are especially valuable for shade trees, not only in the country, but also in towns and cities. The leaves are so smooth that coal dust does not settle on them to stop up the pores, as is so often the case with trees having rough leaves. They always have a bright, clear, vigorous appearance.

The foliage of a poplar tree is not dense, but the leafy top is beautiful and interesting. The leaves are always in motion. One kind, the aspen-leaf poplar, has its leaves so delicately adjusted on their long petioles that they are in constant motion when no breath of air can be perceived by any other means.

In their movement they make a noise like a shower of rain, and may often be mistaken for such, even when the sky is clear.

The leaves are somewhat oval in shape, broad at the base, and pointed at the apex. They are tough in texture, and turn yellow in autumn. 
The blossoms appear in early spring before the leaves are fully out. They hang in aments. When the seeds are ripe they are surrounded by a tuft of long, white hair resembling cotton; hence the name. By means of this cottony substance the seeds are carried long distances by the wind.

The bark is rather light in color, even on very old trees, giving them a cheerful appearance. Solitary old cottonwood trees can be found in many sections of the country. They have few, but large branches, which extend upward nearly parallel with the trunk. With their large arms they stand out in rugged beauty, catching every passing breeze with leaves high in the top, and indicating that activity and mirth are possible, even in old age.

\section{HICKORIES.}

Hickory Trees belong to the family of walnuts. They all bear nuts and compound leaves, making it easy to distinguish them. The leaves are pinnately compound, ending in a single leaflet, which form is known as odd pinnate. The number of leaflets varies from five to twenty-three; the true walnuts having more than the hickories.

'The wood of the whole family is very valuable. Walnut timber is now very scarce, owing to the great demand for it in cabinet work. 'The wood of the black walnut is very dark, and ranks among the most costly of woods for fine cabinet work and furniture. 
Hickory timber is very light in color, splits in straight pieces, is tough and flexible, and its strength is unequalled. Hence, it is the wood much used for carriages and wagons. Spokes for wheels are made of hickory because of its toughness, flexibility, and strength. There is no other timber quite so good for this purpose.

The shellbark is generally considered the best of hickory trees. It grows from fifty to eighty feet high. The branching varies according to the surroundings. In a forest with other trees it sends up a central trunk from thirty to fifty feet high, and then branches out into an irregular head. In an open field, the solitary tree begins to branch near the ground. The branches come out at nearly right angles to the main stem. The main stem is almost always persistent to the top, and the head of the tree is nearly cylindrical in form, with occasional wide gaps between the branches.

Besides its timber and fuel value,-for all hickory wood is the very best for fuel, the shellbark is prized for its fruit. The nuts rank next to the English walnut in food value. The trees begin to bear at about twenty years of age, and continue to old age. A half dozen thrifty trees will bear all the nuts a . family can use. The nuts ripen and fall off after the first frosts of autumn. The outer hull, which is in several parts, bursts open, setting free the brown treasure within, and the nut is ready to crack and eat. 
Probably no other grove of trees would yield a larger income on the amount invested than a small field of shellbark hickories. When bearing begins, the bark peels off and hangs in long, loose, vertical strips; but the younger trees, which would have to be thinned out, have smooth, tight bark. The bodies of such young trees are used for many purposes. They always command a high price. The nuts also have a high standard market value.

A young person who now plants a small field with hickories, will not regret the experiment in after years. The young trees do not bear transplanting on account of the long tap root. Young trees are best secured by planting the nuts where the trees are permanently to stand.

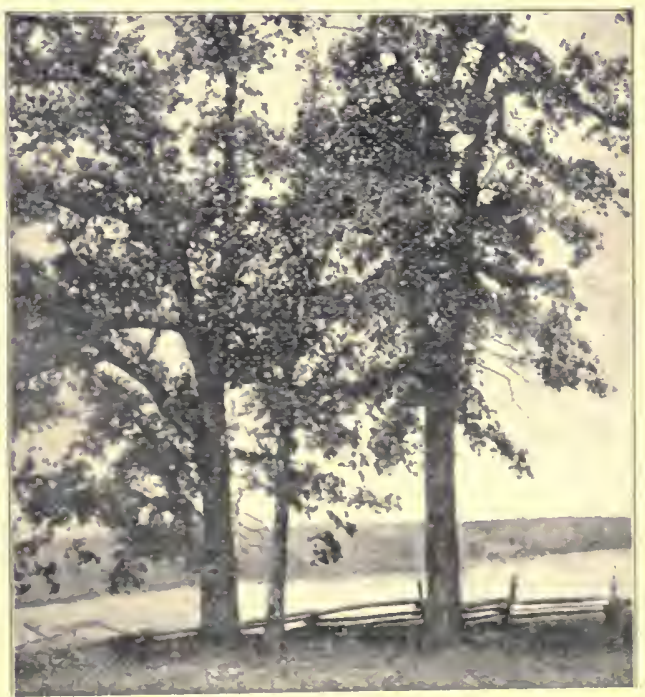




\section{CHAPTER IV.}

\section{INSECTS.}

Stages in insect life. Food and growth of insects. Mimicry and protective resemblance. Cross-fertilization by insects. Destruction of insects. Insects both friends and pests. Insect intelligence. Insecticides. House flies. Weevils in general. The granary weevil. Grain moths. The Indian-meal moth. How to keep out insects. The Hessian fly. The squash bug.

Unlike most familiar animals, insects are interesting on account of the several stages through which they pass. Most kinds are so different in the different stages that one would not think them to be the same creatures. Who would believe that the slow, creeping, worm-like caterpillar would ever become a beautiful butterfly with large wings to sport in the sunlight; or the sluggish, softbodied grub transform into a lively beetle, with hard coat of mail, and wings and legs for rapid locomotion? Such, however, are some of the wonders of the insect world.

There are four stages in the life of the highest orders of insects-egg, larva, pupa, and adult. Some of the lower orders do not pass through all these stages, but, as the young hatch from the egg, they resemble the adult except in size and the possession of wings. In a few species, the young are 
brought forth alive. Two of the four stages are active and two are dormant. The larva and adult are active stages, the egg and pupa are dormant. Since the good or harm an insect does is in its eating, it is essential to find in what stage the most eating is done. In other words, its habits and life history must be learned.

Most moths and butterflies eat an enormous amount in the larva, or caterpillar stage, but only

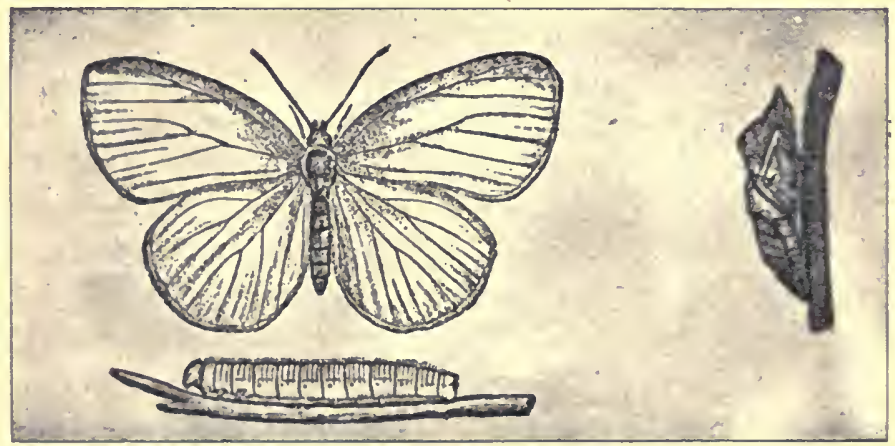

CABBAGE, BUTTERFI, CATERPILLAR, AND CHRYSALIS.

sip a little honey occasionally in the adult stage. Some beetles do as much eating in the adult as they do in the grub stage, but the food generally is of a different character. The Colorado potato beetle lives on the potato plant during all its stages, the larva and adult both eating the leaves; while the cabbage butterfly lives on the cabbage leaf only in the larva stage, the adult flying in the 
air, now and then tasting the sweets of blossoms wherever they may be found.

The larva stage is the one in which growth takes place. A caterpillar, for instance, hatches from the egg a very small worm-like creature. This eats for a few weeks or months, growing all the time, then enters the pupa, or dormant stage, after which no growth in size takes place. It eats during the worm stage not only for growth, but also to lay up stores of fat and other material for future use. During the dormant stage, this supply is changed, elaborated, and built into the organs of the adult insect.

Insects may be classed as soft-bodied animals; that is, they have no inside bony skeleton, but are provided with a more or less hard outer skeleton. With many, it is a mere skin. As growth takes place they find this outside skin, or skeleton, grow too small, and change it from time to time for a new and larger one. This process is called moulting, and has an analogy among many other animals.

Since no growth takes place in the adult stage, some insects take but little food during that timeonly enough to repair waste of tissue and develop eggs. Some eat as voraciously during the adult stage as they do in the larva stage. In a few cases the adults eat nothing at all, and hence have no digestive organs. The May fly lives only a day as an adult, but three years in the aquatic, or larva, stage. It eats enough during its long period of 
early life to supply sufficient strength for the very short adult period. Living for so short a period, it has no time for eating. A few hours are spent flitting in the bright sunshine, the eggs are laid in the water, and its round of life is complete.

\section{INSECT FOOD AND GROWTH.}

- Insects feed upon both animal and vegetable matter. Grubs of beetles eat decayed vegetable matter, such as rotten wood; maggots of flies eat

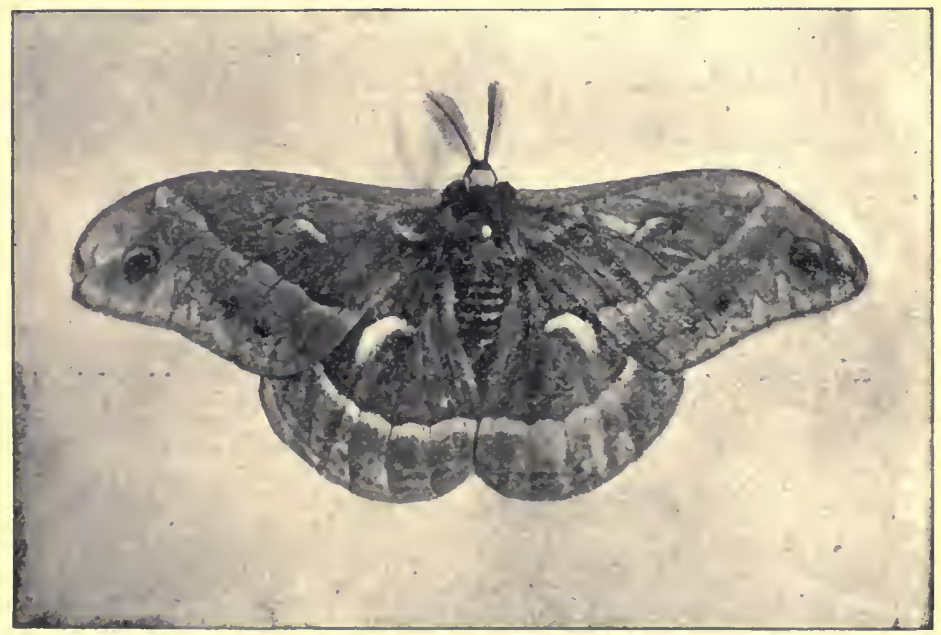

CECROPIA MOTH.

decayed flesh; caterpillars eat leaves; plant lice and squash bugs suck the juices from plants; dragon fies catch and eat other insects; and many kinds 
eat almost anything that they can lay hold of. Ants probably display the greatest amount of intelligence in securing food. They have what are known as "ants' cows" and milk them. The so-called cows are plant lice from which they secure a sweetish substance called honey dew. They not only get it from plant lice while they are on plants, but they also take them to their homes and keep them much the same as a farmer does his cows.

The main function of the adult female insect is to lay eggs, and generally after this act is accomplished, she dies. Insects lay a great many eggs; some, many thousands. This is very necessary to preserve the species, for they are incessantly preyed upon by birds and other animals. Only one or two of every thousand ever come to maturity.

MIMICRY AND PROTECTIVE RESEMBLANCE.

Insects have so many enemies that they have acquired habits and devices by means of which to escape destruction. Eggs are frequently the color of the leaves upon which they are laid, or they are stuck to the under side of leaves to escape detection. The eggs, as well as the caterpillars of the cabbage butterfly, are so nearly of the green of the cabbage leaf that only the closest search can reveal them. The wings of some adult insects are so nearly like certain leaves in form and color that 
the creatures make themselves appear to be a part of the stem upon. which they alight. The insect known as the "walking-stick" so resembles a dead brown twig that it would be taken for such when at rest on a tree or shrub. Some night-flying moths sleep during the day attached to the trunks of trees, and so fold their wings as almost completely to resemble the bark of the tree upon which they rest, and thus avoid being picked up by birds.

Devices for mimicry are almost as numerous as the different forms of insect life. Mimicry, however, is not confined to insects alone, but is common to all classes of animals. It is thought that the stripes of the tiger are there to make it harmonize with the large grass blades among which it lurks. In this case, perhaps, the resemblance is not to conceal the tiger from danger, but that his prey will approach near without seeing him.

Scientists have found that most plants do better when the pollen of one falls upon the blossom of another of the same kind than when the pollen falls upon the same blossom that produced it. The offspring of such a plant does better than others because it partakes of the qualities of two parents instead of those of one. A weakness in one parent may be compensated by corresponding strength in the other. This method of pollination is called cross-fertilization. Plants in which the pollen falls upon the blossom that produced it soun become 
weak and abnormal. Weakness and deformity are transmitted from generation to generation, till the plant is no longer able to cope with others in the struggle of life and thus dies and gives place to stronger forms.

\section{CROSS-FERTILIZATION BY INSECTS.}

Nature is very careful to secure cross-fertilization in plants. The visits of insects to the blossoms to secure the nectar that they find there is the greatest means by which cross-fertilization is accomplished. To secure the carrying of pollen, plants have to pay for it by expending extra strength in producing pleasant odors, sweet nectar, bright-colored blossoms, and such attractive things. Insects would not carry pollen from one blossom to another were there not some reward for their doing it. Odor and color are probably guides to the sweets held by the blossoms. In securing nectar from the blossom, the insect unconsciously rakes off some pollen on his legs and body, and carries it to another blossom, thus accomplishing the desired result.

It must be remembered, however, that the pollen of one blossom will do no good upon the blossom of a different kind of plant. For instance, the pollen from an apple blossom carried by a bee to a pea blossom would not produce apples on the pea vine. Nature, again, has so ordered it that insects visit only one kind of plant while it blossoms, and 
do not wander aimlessly from one'kind to another. When apple trees are in bloom, bees, for example, feed upon apple blossoms; when catnip is in bloom, they teed upon catnip blossoms. When white clover is out, all honey made in the hive during that period is "white clover honey."

White blossoms that are insect-fertilized come

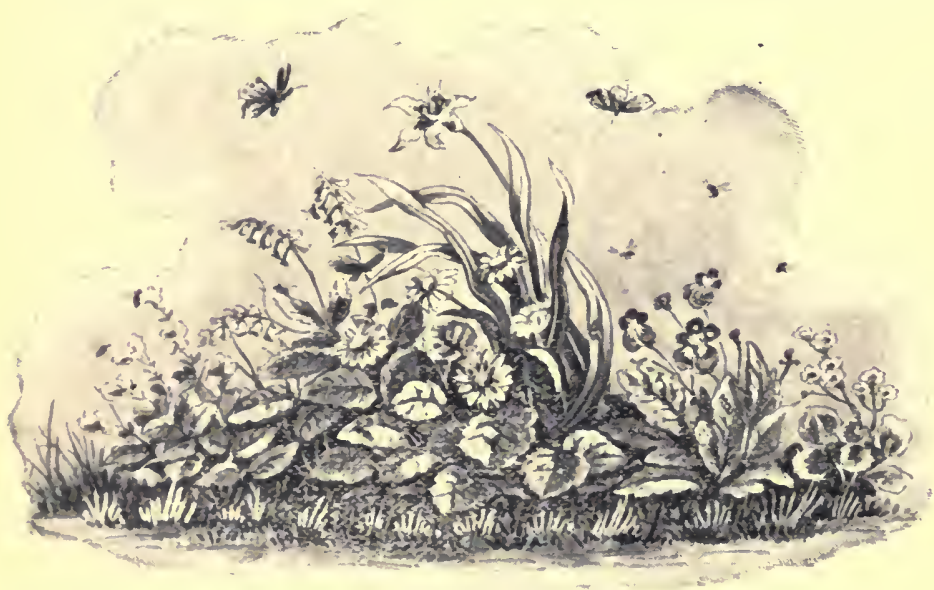

HOW INSECTS CARRY POLLEN.

out at night; colored blossoms come out during the day. So some insects fly by day, and some by night. Certain insects fly by night because certain plants bloom then; or, the plants bloom then because certain insects fly by night.

Tubular blossoms conceal nectar deep down their tubes at their bases, out of the reach of most insects; but some moths and butterflies have for 
tongues or probosces long sucking tubes by means of which they are able to reach it. There is marvellous adaptation in the forms of blossoms and the structure of insects to secure cross-pollination among plants. Some of the most useful farm and garden plants depend upon insects to carry pollen from plant to plant. If it were not for the large bumble-bee, seed would not mature in red clover. The common honeybee carries pollen for the white clover. We are indebted to the same humming, busy creature for abundant crops of apples and many other useful fruits. An apple orchard in full bloom fairly hums with the music of the busy honeybee. Care should be taken in spraying fruit trees not to kill any of these creatures, for they are as necessary to a full harvest of fruit as soil, rain, or sunshine.

THE DESTRUCTION OF INSECTS.

Birds and other animals annually destroy millions of insects in their different forms; insects also kill each other. Otherwise, they would increase to such an extent that no other animate beings could exist upon the earth. This is a well-known fact through the whole animal kingdom: mammals eat mammals; birds eat birds; fish eat fish. Sometimes the parent will eat its own offspring. It seems cruel, but it is, nevertheless, a fact, and is, no doubt, necessary to preserve the balance of power and numbers among animals. 
Some insects, such as lice and flies, make a living by sucking blood out of other animals. Such creatures are called parasites. Insects, too, have parasites that either suck or eat away their vitality. Many ground beetles are literally covered with lice which can easily be seen with the naked eye. The common house-fly has a similar enemy, also a fungus growth that carries off large numbers of them toward the close of summer.

The ichneumon fly probably does as much, or more damage to insect life than does any other creature. It is provided with organs by means of which it pierces holes in the bodies of caterpillars and deposits its eggs therein. These eggs soon hatch and the young ichneumons slowly but gradually eat away the internal soft parts of their host. The caterpillar eats voraciously to supply the waste, but to no effect. When the ichneumons are ready to come out into the world to lead a winged life, they finally eat the vital organs of the caterpillar, leaving nothing but the empty outer shell. A similar fate overtakes large numbers of army worms and grasshoppers.

A large kind of ichneumon has piercing - or rather, drilling organs several inches long. With these it is able to drill holes deep into the trunks of trees to the burrows of wood-boring grubs, upon which the young feed. It can be safely said that ichneumon flies help to keep down the numbers of injurious insects, and are therefore man's friends. 
All forms and stages of insects are the prey of predatory insects. Eggs, larvae, pupae, and adults, fall as victims. The dragon fly has already been
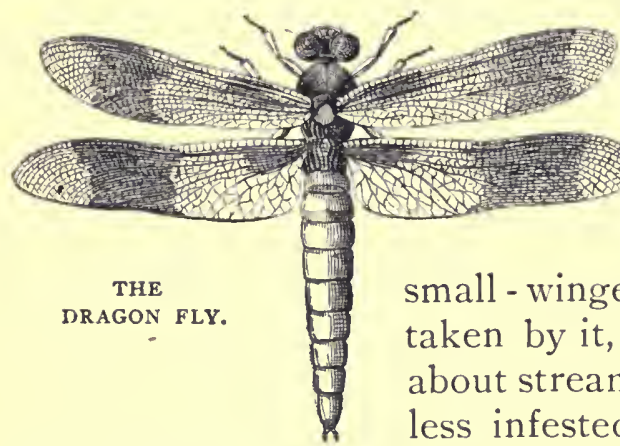
$x^{2}+2+1020$ $x+2$ und sury $x+x+\infty$ wise would be. Beetles not only eat eggs and low forms of insect life in the ground, but chase higher forms over rocks and up trees. The tiger beetle is very useful in this respect. Some wasps, also, kill other insects.

\section{INSECT INTELLIGENCE.}

Although small in size, and comparatively low in the scale of animal life, some of the higher orders of insects display an unusual amount of intelligence, skill and constructive ability. The ant, living a social community life, shows in many ways a marked degree of intelligence. The honeybee is famous for constructive skill in building its geometric cells; it also shows foresight in laying up stores of honey for winter use. Paper wasps not only produce a fair quality of paper, but also 
skillfully build it into serviceable houses. The mud wasp is a mason who knows his trade well, and'can build a more beautiful and complex house than any beaver or bird with the same material.

If any insects can be called domestic, bees and silk moths are truly such. Honey of bees is not only pleasant to the taste but it also has a high food value. It is a common article of diet at all times of the year, and its commercial value is of no small importance. The caterpillar of the silk moth spins material that is worn in some form or other by nearly all of the human race. Silk is not only used for clothing but is woven into fabrics for almost numberless purposes. The silk worm does not thrive well in the United States, yet the silk trade is very extensive. The combined silk industries of the world amount to hundreds of millions of dollars. It seems almost impossible that so small an insect could be of such service to human beings.

\section{INSECTICIDES.}

Different substances are used to kill insect pests of the farm and garden, but certain underlying general principles should govern the intelligent use of all of them. Chickens, as well as other birds, both wild and domestic, like to wallow in dust. They do it to kill the bird lice on them. Insects breathe by means of small tubes arranged along the sides of the body. These tubes, or breathing 
pores, are called spiracles. The spiracles are so small that dust stops them up and breathing cannot take place. Thus the insects die in the dust bath. When infested with lice, birds will take a dust bath in any kind of dry earth. Domestic birds prefer ashes when they are to be had, and will wallow in them in preference to dry earth. Ashes act as dust to stop up the breathing pores of insects, and the alkaline properties attack the tissue, making the destruction doubly sure. Man has copied from nature here and uses several kinds of dust to kill insects with. Ordinary road dust is often used. Lime and ashes are both good, and besides are excellent food for the plants when washed into the soil.

Poisons, such as Paris green, London purple, and sulphate of copper are often sprayed upon plants infested with insects. The insects eat the leaves, take the chemicals into the system, and die by poisoning.

Kerosene, carbolic acid, and similar substances are used because of their strong power to attack and destroy animal tissue. They literally blister or burn insects to death. A mixture of kerosene and soap, or soap alone, may be used with similar results. Soap is very good for the soil, too. There are three general principles then, in killing insects-stopping up the breathing pores, poisoning, and burning or blistering the tissues.

Large worms, or caterpillars, are sometimes 
picked off by hand and killed, when only a few plants are infested; but the process is very slow and uncertain for a large field.

SOME OF OUR COMMON INSECT PESTS.-HOUSE FLIES.

The house fly is one of the most common and familiar of all insects, and needs but little description. It belongs to the order of two-winged (dipterous) insects. There are four stages in its life-history-egg, larva, pupa, and adult. The larva is a small, worm-like, white maggot, and differs very much in form and habit from the adult. Maggots have mouth parts fitted for eating solid substances, while adult flies have them fitted for sucking liquids.

Flies breed in filth and in decaying animal and vegetable matter, especially the former, or a mixture of both. So the presence and number of flies depend upon the amount of decaying organic matter in a neighborhood-governed, of course, by the time of year or by the temperature. They breed in nearly all parts of the world, but do so most abundantly in warm countries.

After eggs have been laid in filth of any kind, it takes but a few hours for them to hatch. The maggots eat for a few days, molt, or change their skin, twice during the time and then go into the pupa, or resting stage. 'The pupa stage lasts about five days. So it is less than two weeks from the time that eggs are laid till adults come forth. 
An individual female fly lays about a hundred eggs. From this it can be seen that a single fly could give rise to many millions during a single summer.

It cannot be said that house flies are injurious; on the other hand, they do a great amount of good in destroying decaying organic matter. They are however, very troublesome to both man and beast. It is believed by some that germs of disease attach themselves to the bodies of flies and are thus carried from place to place. The truth of this theory is possible, tenable, and, indeed, highly probable; for flies are a common nuisance in sick rooms, and germs of disease adhering to them could be carried to, and infect, another person as easily as they could by the body or clothing of a human being.

Different remedies are proposed. Garbage about the house should be quickly and carefully disposed of. Thorough cleanliness in the house, and careful screening of doors and windows will keep them out to a large extent. Cleanliness here implies that no sweet substances or food be left exposed, for they attract flies in larger numbers than almost anything else. They congregate wherever there is anything for them to eat or to lay their eggs in.

A stable in which horses are kept will breed enough flies for a whole neighborhood. Stables should be swept clean daily and the refuse matter carted away to the fields and plowed under, or put 
into a tight tank and sprinkled with kerosene. Chloride of lime will also kill maggots, but it is too expensive to be practicable.

Flies have several natural enemies. They are subject to disease, they are picked up by birds, and, in the larva forms, are eaten by beetles; but they breed so fast that the effect of this destruction is seldom noticed. The only true and practical remedy for the nuisance they become lies in the combined efforts for cleanliness of every one owning stables, dwellings, or other buildings, in or about which decaying organic matter may accumulate.

\section{WEEVILS IN GENERAL.}

Under the head of weevil all those insects may be included that injure stored grain. There are many kinds of them, so only the most general description will be here given.

Vegetables and fruits containing a large percentage of water can be kept in store only a few months. Water is very conducive to decay, but the so-called grains contain such a small percentage of water that they will keep for years in dry places without change. Owing to the small amount of water and the large amount of solid food in grains, they have become world-wide staples of consumption. Being so condensed in bulk, they can be shipped very long distances with profit, and people of countries not producing them are able to secure supplies almost as cheaply as if they were 
native to their own soil. The United States receives rice from China, and, in turn, sends wheat and corn to other countries. Countries and sections of countries are able to tide over years of scarcity and famine for the same reason.

Although grains are rich in food value, and have such good keeping qualities as far as decay is concerned, they are subject to injury by several kinds of insects, all popularly known as "weevils." These are very small insects, and hence can easily infest a quantity of grain without being discovered until a considerable amount of damage has been done. Not only is there a loss in weight, but the insects' bodies and excreta make it unfit for use as food. Some kinds destroy the germs of the seed so that they will not grow when planted, whence there results a diminution of the crop.

Insect injuries to ripened and stored grains amount to many millions of dollars annually in a single State. In some cases nearly half of the corn is destroyed by them. The annual loss in the whole United States probably amounts, on an average, to nearly a hundred million dollars.

Heat and dampness are conditions favoring the increase of such insects. Heat helps the eggs to hatch. Dampness renders the grains soft, so that they can be easily eaten. The husks of grain being primarily for protection, the husked varieties are subject to greater ravages than those from which the husks have not been removed. 
Many different articles of food are now manufactured from grain and put up in packages. If such foods are made of uninfested stock and sealed immediately in insect-tight cases, the articles can be kept for a long time. All insects hatch from

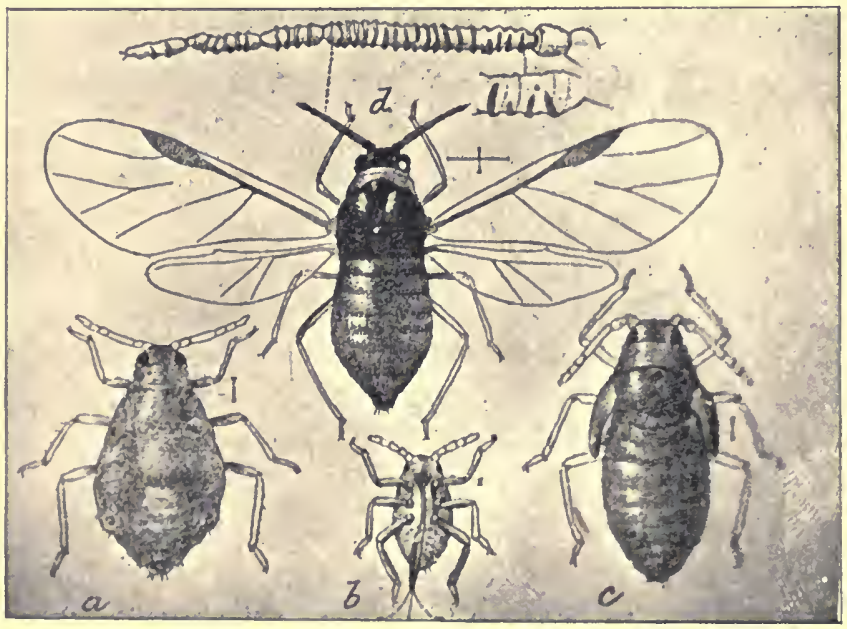

WOOLLY APHIS OF THE APPLE.

$a$, agamic female; $b$, larval louse; $c$, pupa; $d$, winged female (with enlarged antenna above.)

eggs; so, if the box containing the food is sealed tightly with paper, or similar material, so that the adult cannot lay its eggs in it, none will hatch and the food will be safe. Many such articles are now put up in small pasteboard boxes and carefully sealed over with a thin covering of paper. 
THE GRANARY WEEVIL.

The granary weevil is a small beetle which has been known for centuries to injure stored grain. The adult insect is about an eighth of an inch in length and brown in color. The female punctures the grains of wheat with her snout and lays her eggs in the cavities. When the eggs hatch, the larvae devour the mealy interior and then undergo their transformation. In the small cereals a single grain furnishes a house for but one larva; but in the larger kinds, such as Indian corn, a kernel furnishes a home for several individuals.

The adult beetles, as well as the larvae, eat the grain. They are quite prolific and will breed several generations during a year. One pair may give rise to several thousand individuals annually.

GRAIN MOTHS.

These small moths infest all kinds of grain, and are destructive in fields as well as in bins, because of the adult's power of flight. The caterpillars do the damage. After hatching from the eggs, they burrow into the grain and eat out the starchy matter. They soon mature, spin silken cocoons, enter the pupa stage, and transform into adult moths- to pass again through the cycle of life. They do more damage in the Southern than in the North. ern States. 
THE INDIAN-MEAL MOTH.

Another moth, known as the Indian-meal moth, because its caterpillar infests the meal of Indian corn, is very common in many parts of the United States.

It is a well-known fact with those using corn meal that it will not keep long in summer, but becomes stringy. This stringy substance is caused by the small caterpillars of this insect spinning large quantities of silken threads, to which the particles of meal adhere. They also deposit a great amount of excrement, which makes the meal unfit for human consumption. No amount of sifting will thoroughly clean it.

There are also many other moths and beetles that damage flour and grain, but their habits are so similar to the ones already given that a description here is not necessary.

\section{HOW TO KEEP OUT INSECTS.}

Granaries, bins, and storehouses for grain should be lined with tight-fitting boards, then painted or whitewashed to stop up as many cracks as possible. After removing the grain at the end of each season, they should be carefully swept, cleaned, and repainted, or whitewashed. No crevices should be left as lurking places for insects. Doors should be tight-fitting, and other openings carefully screened. Thorough cleanliness will go far to 
keep down the ravages of insects. Grain should be harvested and threshed as soon as possible to prevent the winged forms of insects from infesting it in the fields.

For stored grains, bi-sulphide of carbon seems to be the best and most practical insecticide. Bi-sulphide of carbon is a liquid with a strong, disagreeable odor. It vaporizes readily in the free air, is highly inflammable, and a powerful poison. It is very effective in killing insects, but it does not injure the grain. The liquid can be placed in dishes above the grain and allowed to vaporize. The vapor is heavier than air and soon sinks through the mass of grain to the bottom of the bin, killing all vermin therein. The liquid is put up in tin cans, is cheap, and easy to handle.

\section{THE HESSIAN FLY.}

Besides being injured by weevil in the bin, wheat is also subject to attack in the field by a still more formidable enemy, known as the Hessian fly. It is held by some that this pest was introduced into the United States during the Revolution by the Hessian troops. It began its ravages in the vicinity of their landing, and was probably brought over in straw, which they used for bedding. The first injuries were noticed in 1779 .

There is an annual loss in the United States of about fifty million bushels of wheat, due to the ravages of this insect. In some localities there is 
a loss of from one-half to an entire crop. The Hessian fly is a wheat insect, but it will also breed in a few other grains.

The adult insect is a small fly about one-eighth of an inch long, and dark in color. Like all flies, it passes through four distinct stages-egg, larva, pupa, and adult. The pupa stage for this fly is known as the "flaxseed stage," owing to its resemblance to that seed.

The second, or maggot, stage is the one that does the damage. Eggs are laid by the adult on the leaves or stems of wheat. They hatch in a few days, and the white maggots eat the tissue and suck the juices from the stalks. Sometimes their injuries cause enlargements to grow on the stems at the point of attack. If the injury is great, the plant falls to the ground.

Most wheat plants respond to the injury by sending up new, shoots; but these, in turn, are generally infested, so that only a partial crop is the result. Hardy varieties, that is, those with hard, flinty stems, sustain the least injury because the straws do not bend easily at the injured points.

No remedy has been found to save a field when once infested with the Hessian fly, but careful measures may save succeeding crops. Since the flies work on the lower joints of the stem, they may be left in the field by cutting the wheat high. If the stubble is then burned, they may be destroyed. Another effective measure is to plow under the 
infested stubble and plant the field with some other crop the next year. Late sowing of winter wheat will often prevent the crop from becoming infested, because the adult flies perish on the approach of cold weather and hence no eggs are laid on the young plants. This method is not always practicable, because wheat sown too late is in danger of being winter-killed. Probably the surest method of destroying the pest lies in the rotation of crops.

It must be remembered, however, that, after all precautions have been taken, a neighbor's brood may easily fly over and defeat your precautions.

\section{THE SQUASH-BUG.}

By a great many people all insects are called "bugs." It is right to say that all bugs are insects, but not that all insects are bugs, any more than it would be to say that all birds are thrushes. One order of insects may be called bugs. It is distinct from all the other orders, and may be known in several ways. The main characteristic is the mouth, which is fitted for piercing the tissues. of plants and sucking their juices. Many bugs undergo an incomplete metamorphosis; that is, they have no distinct pupa stage, but the insects hatch from the eggs and closely resemble the adults, with the exception of wings.

The stage between the egg and the adult is commonly called the nymph stage. This is the stage in 
which growth in size takes place. The nymph molts, or sheds its skin, several times to allow its body to grow. When the adult stage is reached wings appear, and growth in size stops. The adult eats in order to develop eggs for a new generation.

The common squash-bug is so called because it is the best known of all insects that infest pump-

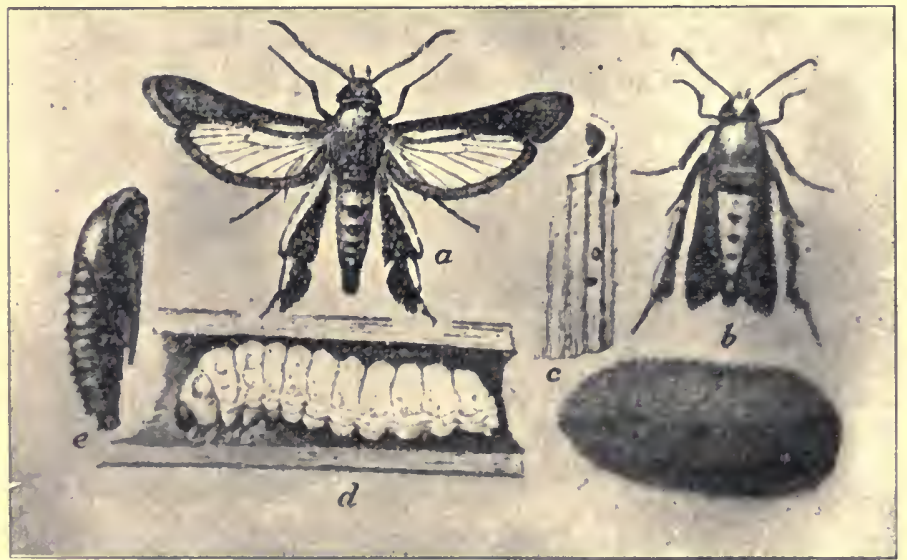

SQUASH VINE BORER.

$a$, male moth; $b$, female; $c$, eggs on a bit of squash stem; $d$, fullgrown larva in situ in vine; $e$, pupa; $f$, pupal cell.

kins and squashes. It is a true bug, having highly developed piercing and sucking mouth-parts, and undergoing incomplete metamorphosis. Its near relatives are bed-bugs, plant-lice, animal-lice, scaleinsects, cicada, and a host of other pernicious insects. It can truthfully be said that they are the most despised of all the class. 
Squash-bugs are popularly known as "stinkbugs," from their disagreeable odor. The adult bug is about three-fourths of an inch long, dark. brown above, and mottled-yellow beneath, the long, jointed feelers prominent, and the wings folded diagonally across the back.

Eggs of the squash-bug are generally laid on the under side of the leaves of the plant on which it feeds. They are nearly white when first laid, but soon change to a dark color. The eggs hatch in a little more than a week; the young nymphs are dark in color. They are green and black, and also assume reddish or brownish tinges before maturity.

Injury to the plant is done by the insect's piercing a hole and sucking the juices. It attacks not only the vines, but also the leaves and fruit. The insect is more or less harmful during its entire active life. When a great number attack a plant, the juices are soon sucked away and the plant is sure to die. If the fruit alone is infested, development ceases. It is not only the sucking out of the juices that destroys the plant; but, in puncturing the holes, the insects inject a drop of liquid which has a poisonous effect upon the plant.

Young plants sustain greater injuries than older ones; but at any time during the season sufficient numbers will completely destroy a crop. Sometimes the attack is not begun till the fruit is nearly developed; but even then the bugs may cause it to be unfit for use. 
At the end of the season, or when the squash. Lug has finished eating, it hides away in rubbish. among the dead vines, under bark and stones, or under almost anything it can find. It thus passes the winter in hibernation, ready to come out the next summer and lay eggs for new generations.

No satisfactory chemical preparation for killing the squash-bug has been found. Anything strong enough to kill the insect will also kill the plant. Owing to their habits of concealment, a careful cleaning up of old vines, and burning, will destroy a great many of the bugs. It might also be said here that a careful raking up and burning of all the dead plants in gardens and truck patches would help to keep down the numbers of many injurious insects. Different plants attract different insects, so that a garden soon becomes a pesthouse for many kinds .

A good plan is to cover the garder a few inches ceep with dry straw, spray the whole with a few gallons of kerosene, and burn. The cost of doing this, and the labor, would be recompensed many times. It must be remembered, however, that sone forms pass the winter in the ground and wound not be affected by such methods.

Another, and probably the most reliable way to keep down the numbers of this pest, is to watch carefully early in the season for adults, to destroy them by hand, and to cut off leaves, or portions of leaves, to which eggs adhere. 


\section{CHAPTER V.}

\section{BIRDS.}

The food of birds. Relation of birds to agriculture. Utility not the only measure of the value of birds. Individual birds:-the woodpecker, the swallow, the meadow lark, quails, sparrows, the wren, the robin, bluebirds, the bobolink.

It can truthfully be said that some things in the world are very important because we cannot live without them.

The fact is that all things have a place in the world, and contribute in some way or another to make it a fit abode for man.

Without air or water, life of all kinds would soon come to an end. Without plants, animals would have nothing to feed upon. Were all fishes of one kind, some climates and some waters would be without fish. In the cycle of life, each individual is dependent upon its surroundings,

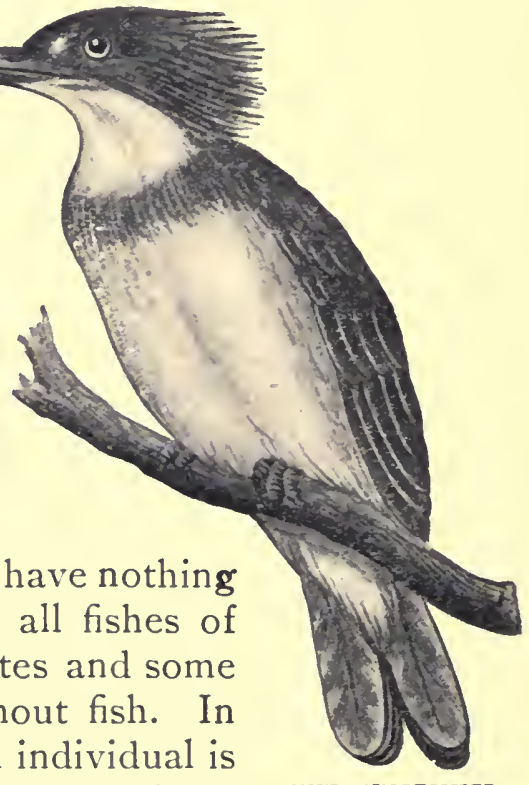

THE KINGFISHER. but, in turn, helps to make those surroundings fit for others. 
It is not true that we could not live upon the earth another day if all birds were killed, but life would not be so pleasant without them. Farming and gardening would not be so profitable; neither could shade and fruit trees be grown successfully because of the great numbers of insects that would thrive if left unmolested. We shall study birds, then, mainly with reference to the good they do in killing pernicious and injurious insects.

\section{THE FOOD OF BIRDS. $:$}

Birds, like other animals, require food. Some eat one thing and some another. Some live entirely upon a vegetable diet, some on an animal diet, and some on a mixture of both vegetable and animal food. The greatest number of birds belongs to the last class; that is, the kind that eats both vegetable and animal food. The diet of birds, at first thought, seems to be of little importance; but, upon careful study, it is found to have a vital relation to the success of farmers and gardeners, and to be of general importance to all.

In studying the food of birds, we shall find out many important things about their structure and habits. For instance, as winter approaches in our northern latitude, food becomes scarce. This compels some of our birds to fly to warmer regions, where food is abundant. Then, again, as summer approaches, they come back to the fresh and unoccupied fields where there is no lack of 
food during warm weather. Hence, the migration of birds is almost wholly dependent upon their food supply.

Some birds stay north during the cold winter, when the ground is

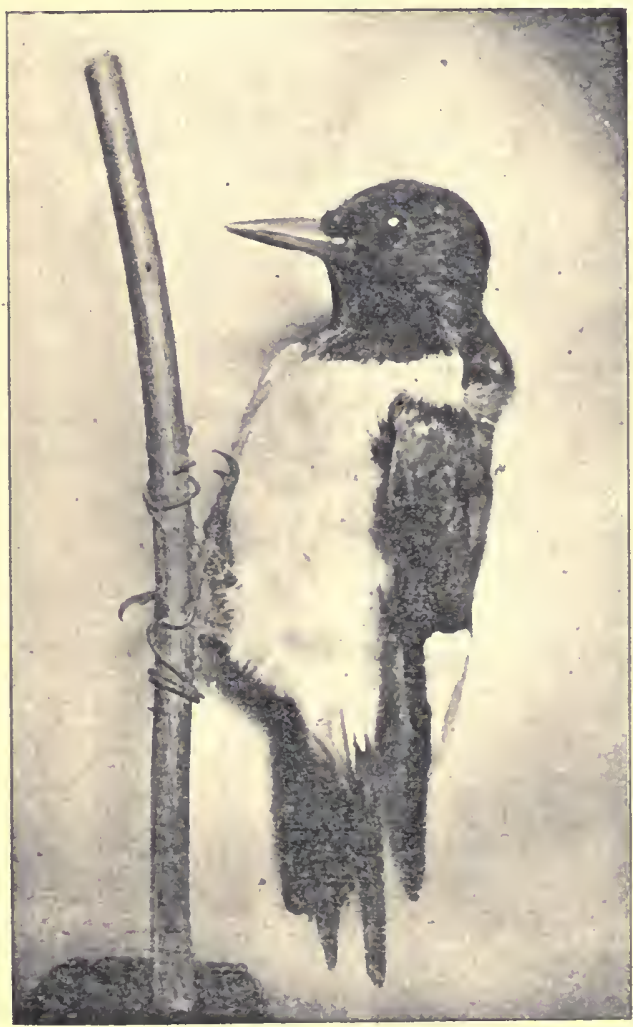

THE WOODPECKER. covered with snow and ice, a nd all insects a re dead or hid$\mathrm{d}$ e $\mathrm{n}$ a way in a dormant state. Such birds are found to be well fitted to secure a living even during the severe winter, though $\mathrm{th}$ e odds seem to be against them.

The woodpecker is a good example of this kind. $\mathrm{He}$ staÿs north because his food is as easily secured 
during the winter as it is at any other season of the year.

Woodpeckers feed largely upcn those grubs of insects which burrow in the trunks and branches of trees. Their feet are fitted for clinging to the bark; their tails for supporting them while at work; their long, sharp bills for pecking holes in the wood to the grubs; and their slim, barbed tongues for piercing and dragging out the victims. So the structure of woodpeckers, to a large extent, depends upon the food they eat.

The same is true of hawks and owls (see p. 135), which kill and eat birds and other animals. Their feet are fitted for catching and holding their prey, and their sharp, curved bills for cutting and tearing the flesh. The structure of the swallow's wings, tail, and mouth, is due to the fact that it lives upon winged insects and must catch them in mid-air.

Birds that catch fish and other small animals in the shallow water of swamps and streams, have long legs for wading, and long bills and necks for reaching deep into the water. Ducks and geese secure their food in either deep or shallow water, and have bills especially fitted for straining out the indigestible mud and other material. So the list continues,-each bird having something peculiar and interest' $\mathrm{g}$ about it, due to the food upon which it subsi: ;. 
RELATION OF BIRDS TO AGRICULTURE.

Until recent years, very little study of birds in their relation to agriculture has been made. Now, however, farming is reduced to a scientific basis, and many principles have to be considered to make it a successful pursuit. It is further admitted by all that insects are destructive to many crops, and that the reduction of their numbers, and holding them in check, must be seriously considered.

Artificial methods of insect destruction are frequently expensive and unsatisfactory. Often they cannot be used at all; and the producer is compelled to stand aside and see the results of his labor vanish before his eyes, with no means of help. There are times, too, during the busy summer's work, when the farmer feels that he cannot stop other work to kill insects. So they are permitted to increase till some valuable crop is destroyed.

Now, the presence of birds is a natural means for keeping in check the harmful ravages of injurious insects. Birds never cease working. They rise early in the morning and retire late in the evening. All day long they pick up insects of all kinds, which they eat themselves or carry to their young

There are no holidays with birds. Sunday and Monday are alike with them so far a eating is concerned. A farmer, then, may leav his fields one day in seven and know that the insect exter- 
minators are still at work, if he is friendly to useful birds and allows them to live on his farm unmolested. It pays in more ways than one. Birds appreciate human kindness and protection as few other animals do.

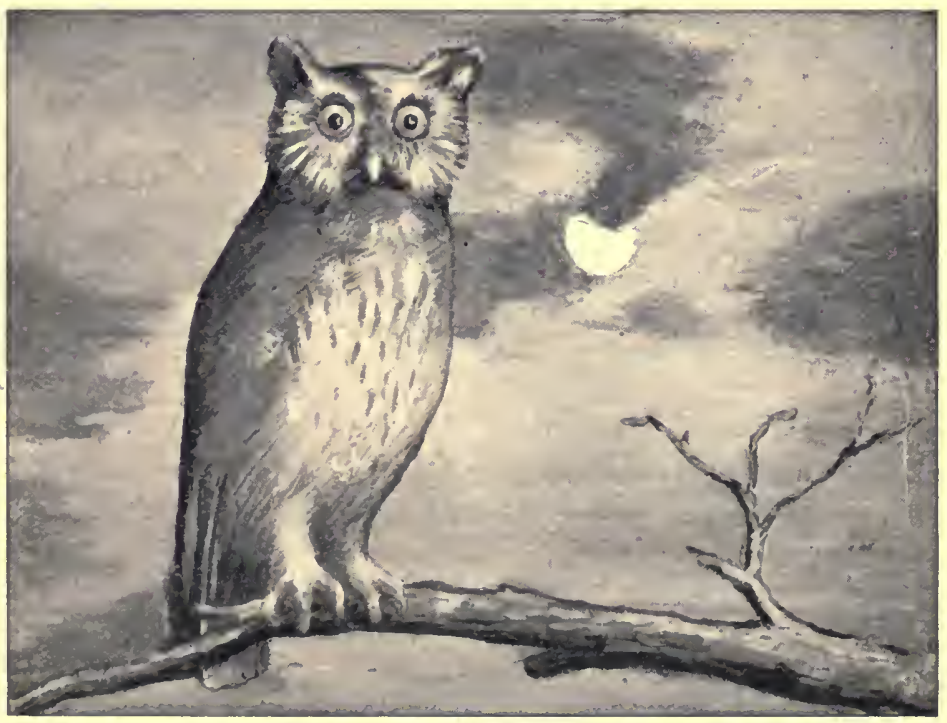

THE SCREECH OWL.

Birds are now protected by law in many States. In some localities, however, there is so little thought taken of the law that it is not strictly enforced. It thus happens that thousands of our most beautiful and useful creatures are sacrificed wantonly, or for the table, or for the capricious 
decoration of women's hats. And yet, in this enlightened time, it does seem that no thoughtful woman ought to consent to wear any part of a bird as an ornamient.

During the summer months, the main diet of birds consists of soft-bodied insects, such as grubs ard caterpillars. This is especially true of young birds in the nest. Such forms are more easily swallowed and digested than others. Seeds are too hard for their tender stomachs. Adult birds eat seeds because they are able to digest them. The number of seeds, however, generally falls far short of the number of insects taken. It must not be forgotten, too, that young, growing birds require more food than full-grown ones, so the grain eaten by them after they are able to shift for themselves is fully compensated for by the great number of insects eaten while they are young.

UTILITY NOT THE ONLY MEASURE OF THE VALUE OF BIRDS.

Young birds in the nest should, therefore, be looked upon not only as interesting subjects for care and study, but as the most useful of all wild creatures that live on a farm. It is a well known fact that only a small part of the birds born ever arrive at maturity. Before they are able to fly from the nest, young birds are taken by animals of prey, are killed by lice in the nest, are killed by severe storms, or they die of starvation because of 
accidents to their parents. Now, since they eat insects almost wholly during that period, it is quite evident that their value to the producer is very great, even though the surviving adults may eat a few grains of wheat or corn.

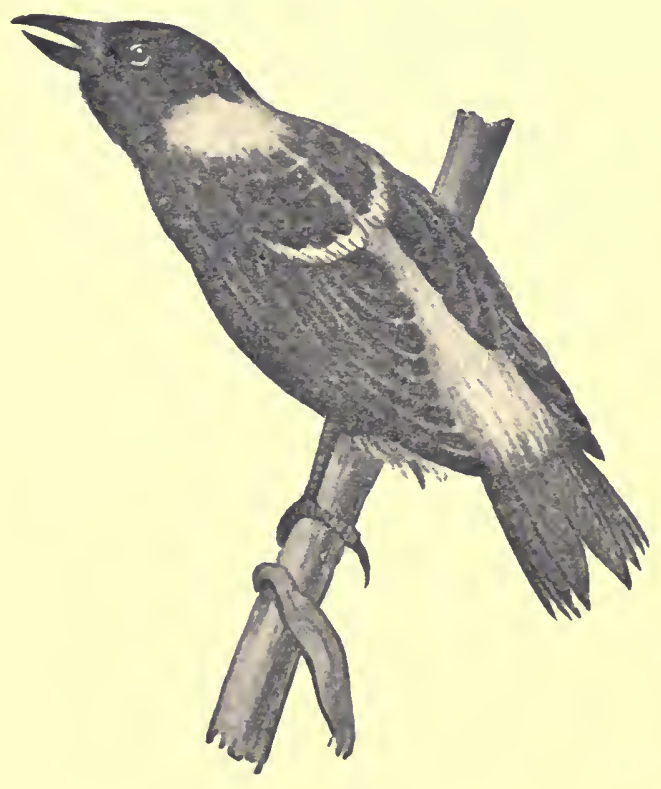

THE BOBOLINK.

Nor should the side of utility alone be considered when the feathered tribe is studied. Birds are not only the most beautiful, but also the most cheerful creatures about a place. Their beauty of form and covering is unsurpassed by that of any 
other class of animals. Most creatures are dumb, or they only occasionally utter a few unmusical sounds. Birds, on the other hand, are the most musical of all animate creation, with the possible exception of man. There are but few species that do not utter pleasing vocal sounds.' Many of them pour forth music of such volume and sweetness that the appreciative ear could never tire of listening.

The songs of birds are missed during the winter months, but sound the sweeter when the wave of migration comes pouring over the North in spring. During the early summer months, (their mating season,) their songs are especially joyful. The songs of most birds are clearest in the early morning, but many kinds sing well all day long. A rural scene without such sounds would be lonely indeed. Fortunate are those people who are privileged to enjoy such harmony.

Our knowledge of the good or of the harm done by birds does not rest upon general observation alone. The United States Department of Agriculture has carefully examined the stomachs of several thousand individual birds. On an average, about 75 per cent. of the contents was found to consist of the bodies of insects, most of which are destructive to cultivated plants. Some species examined were found to subsist almost entirely upon insects, while only a few ate more grain than other kinds of food. 
With such facts in view regarding the usefulness of birds in keeping down the numbers of injurious insects, the farmer, the gardener, and the fruit grower should combine their efforts for the protection of these valuable little friends.

INDIVIDUAL BIRDS.-THE WOODPECKER.

There are several species of this bird in the United States. As the name implies, it lives where wood is found. Now, trees furnish homes for many kinds of animals, especially insects, which feed upon the leaves and wood. Grubs, caterpillars, and ants eat into and destroy the trunks and branches of trees. Woodpeckers are better fitted than any other birds for capturing these insects.

Until recently, before its true office was known, the woodpecker (see p. I32), was held in contempt by most people. They looked upon it as a worthless creature, going about amusing itself by pecking needless holes in trees, or drumming upon the boards of buildings.

But those looking carefully into the matter have found that such holes have been the salvation of the trees in which they were pecked. Out of each hole drilled by the bird a pernicious insect was extracted and eaten. In many cases, of course, the trees died,-not because of the holes made by the birds, but because the insects were so numerous. The inside of such trees, when they are cut down and split open, is found to be tunneled, or "honey- 
combed," in every direction by the holes made by insects.

The writer well remembers the time when woodpeckers were killed in southern Illinois at all seasons of the year merely for the sport of shooting them. At the same time thousands of dollars' worth of trees were destroyed annually by one insect alone-the wood-borer. It is not likely that woodpeckers could have entirely eradicated the evil; but they surely would have helped greatly in keeping down the number of insects, had they been allowed to breed unmolested. It is to be hoped that these birds will not be slaughtered again for mere sport.

Woodpeckers eat some vegetable food; but as most of it is of a wild variety, not much damage is done to cultivated crops. There is some doubt, however, as to one small species, known as the "sap-sucker." This bird pecks holes into the branches of trees for the sap which flows into them. It is thought by some that he more than recompenses for this bad trait in capturing insects attracted by the sap in the holes which he has pecked. At least, we should not condemn the whole family for the misdeeds of one member.

There is probably no place in which woodpeckers can do more good than in an orchard. They should be induced to stay there rather than driven away. When a woodpecker is seen running up and down an apple tree, pecking vigorously at times, 
this does not mean that it is trying to injure the tree, but that it is clearing the tree of enemies lurking in the wood and under the bark.

Nor do woodpeckers confine themselves to trees. Often they alight upon the ground for prey, catching beetles, ants, and even grasshoppers.

Most species of woodpeckers stay in the north the year round. They keep us company when other birds have flown away. They are the greatest known conservators of trees of all kinds, and should be held in high esteem by those who love trees and know their value.

THE SWALLOW.

Swallows are very much unlike woodpeckers in their general structure and in their habits. In the main, however, they accomplish the $\mathrm{s}$ a m e end; na m ely, the killing of insects. Just as w o o d p eckers

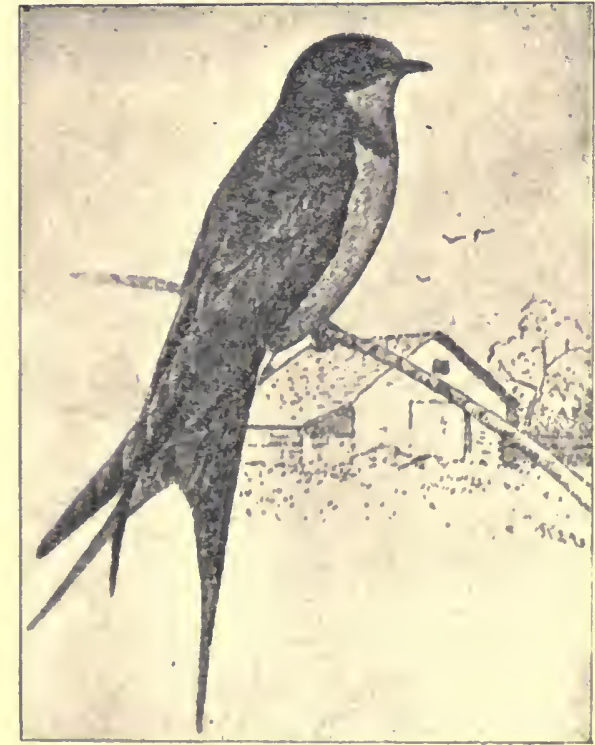

THE SWALLOW. 
have long bills, barbed tongues, strong muscles of the head and neck, easily adjustable toes, and stiff tail-feathers, to enable them to secure insects from the trunks and branches of trees; so swallows have large wings, strong muscles of the chest for support in almost continual flight, long tails for guiding, sharp eyes for seeing, and a very large mouth to enable them to catch insects in mid-air.

Some insects lead a sluggish life, hiding away for long periods, and moving very slowly within a small sphere; others are very active, flying almost continually in the air. Since different insects have different modes of life, then those animals that prey upon them must adapt themselves to certain conditions in order to secure the necessary supply of food.

Since some insects burrow in wood, then birds, to secure them, must be able to dig into the wood. Since some insects creep on the ground among grass and weeds, then birds, to secure those kinds, must walk upon the ground, with their bills and eyes pointed continually downward. Since some insects spend most of their time flying in the air, the birds that catch them must also fly in the air. It always requires effort to secure food; and this struggle on the part of animals has a tendency to change their structure.

Now, on account of the large, strong wings, and long, steering tails of swallows, they are able to fly almost continually. This makes them especially 
helpful in ridding the atmosphere of certain noxious and troublesome insects. When a swallow is seen gliding swiftly through the air, up at one moment, down at another, and turning a backward somersault at another, he is not doing it for the mere sport of expert acting. In every case it will be found that he is close upon the heels of some swift-flying insect, and must needs follow its devious course in order to catch it. Just as woodpeckers keep trees free of insects, so do swallows perform a similar service for the atmosphere.

It is a well-known fact that swallows all fly south early in autumn. This is very necessary. Living, as they do, upon insects of the air alone, their food supply soon vanishes on the approach of cold weather. They are then compelled to seek a climate where the air is warm enough for insects to be found.

Most swallows are social in their habits, and will build their nests in and about barns and other farm buildings, if allowed to do so. They should be encouraged in this habit. They will pay many times over for the trouble of providing for them in keeping the summer air around the premises clear of insects troublesome to both man and beast.

THE MEADOW LARK.

The meadow lark is distinctively a ground bird. It nests on the ground and feeds on the ground. Now and then it can be seen sitting for a few min- 
utes on some telegraph post or tree, but it prefers not to get farther away from the earth than a fence-top. Few other birds spend their lives so low down as the meadow lark.

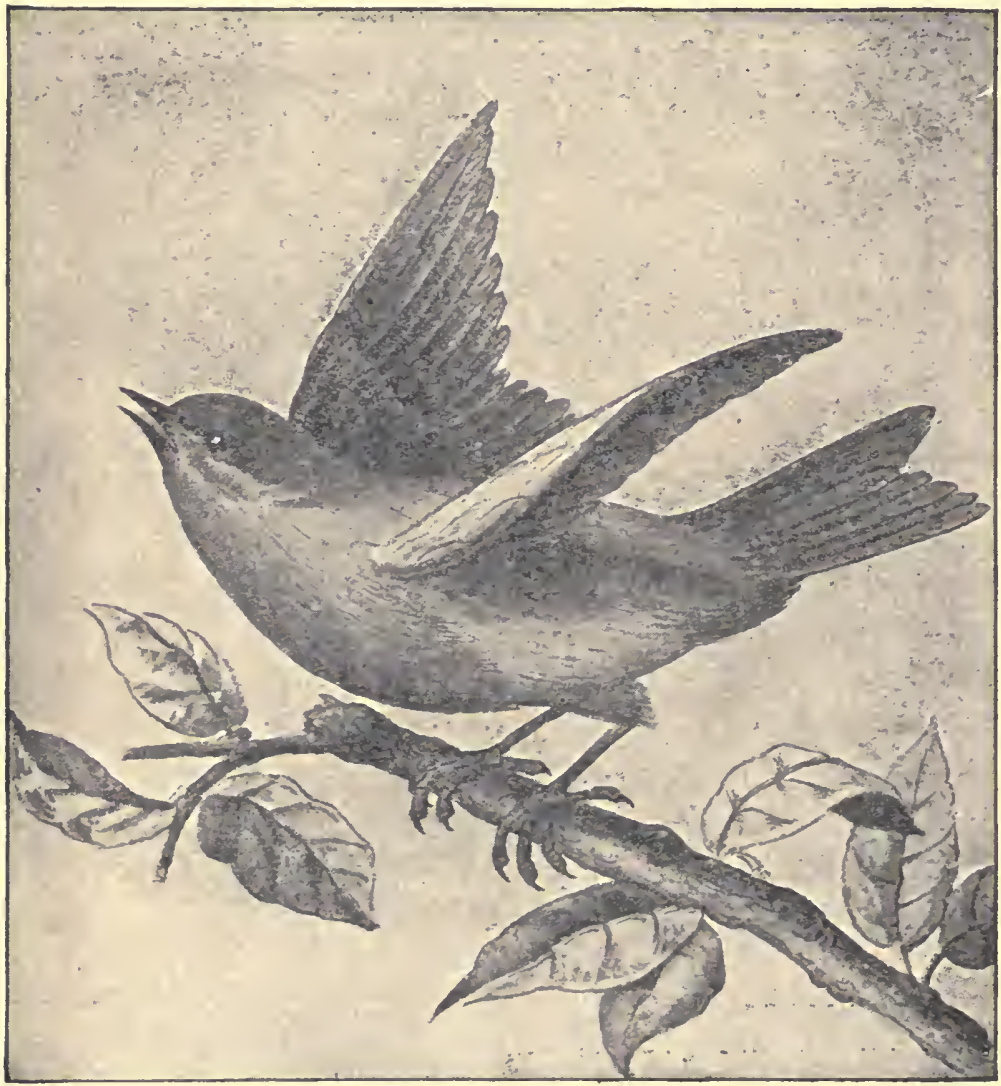

THE BLUEBIRD. 
From careful examination it has been found that the food of meadow larks is made up largely of insects. Its vegetable diet consists of a few grains of cultivated plants, and the seeds of noxious weeds, - the latter almost wholly predominating. The insects eaten are mostly beetles, caterpillars, and grasshoppers.

Some of these beetles are injurious to cultivated crops and some are not. The caterpillars are those popularly known as "cut-worms," an insect most destructive to grasses,-young corn especially. Cutworms are difficult to kill by artificial methods from the fact that they spend a great deal of their time beneath the surface of the soil. They come up only long enough to cut off stalks of young grass, which they drag back into their holes. The destructive work of grasshoppers is so well known that it needs no comment. They, too, are difficult to handle by artificial methods.

During the grasshopper season, meadow larks, as well as many other birds, eat very little other food. Female grasshoppers make small holes in the ground and lay their eggs therein. During this process, myriads are snapped up by the meadow larks before they have time to deposit their eggs. This diminishes the number that would be hatched out the next season.

'The meadow lark goes south only when it is compelled to do so by severe weather. It stays ali winter in portions of southern Illinois, and in 
the same latitude elsewhere. It is even successful in securing some insects during this cold season, as is evidenced by the examination of its stomach. It is able to subsist for some time on a vegetable diet, weed seed especially, and returns farther north very early in spring.

Meadow larks are often killed just for the sport of shooting at them, and some are killed for food. When, however, the great value of these birds is known, it is hoped that all such wanton waste will stop entirely.

The song of the meadow lark is not so sweet as that of the famous English lark, nor as that of some other American birds; but it is of no mean character. Most of our best song-birds dispense their music from the tops of shrubs or trees, and seldom from the ground in open fields. The meadow lark, however, cheerful at its work in its lowly station, pours forth happy, whistling notes all day long, where otherwise silence and monotony would reign.

SOME OTHER BENEFICIAL BIRDS.

The limits of this volume will not permit a description in detail of the habits of all useful birds in this section of the United States. So we must be content with a passing notice of only a few more.

The value of quails as insect destroyers has long been known by the farmers of the Central Siates; 
but, being so highly prized for food, they have become favorite game birds. Nothing but the most stringent game laws will ever stop their slaughter.

Most States now have laws which prohibit the killing of quails except for a few weeks of each year. During those few weeks of non-protection, however, they are shot or trapped in such large numbers that it is a wonder any remain for the next season's breeding. If the maximum amount of good is to be derived from these birds, laws must be enacted to prevent their being killed at any season of the year.

Quails, like a number of other useful birds, eat some wheat, oats, and corn; but the grains are mostly those that shatter off in the fields and would never be utilized. When undisturbed for several months, quails grow very tame, and will feed near dwellings, or bathe in the dust of country roads almost within arm's reach of the passerby. They are very prolific, and would soon increase to sufficient numbers to do a vast amount of good if they were not annually killed down to comparatively a few individuals.

Sparrows are also very useful birds. In addition to the many noxious insects taken, they eat large quantities of the seeds of worthless weeds. Few seeds of useful plants are eaten by them. The much-despised English sparrow probably does much more good than harm. It does not drive 
other useful birds away to such an extent as it has been accused of. Most of its vegetable diet consists of refuse or weed seed. Its value as an insect destroyer during the summer months cannot be questioned.

During the summer of 1900 , the writer watched a male and female English sparrow carry food to a nest of half-grown young. The food brought consisted entirely of cabbage worms (caterpillars of the cabbage butterfly), and the number amounted to an average of about fifteen per hour. Now, taking into consideration that the summer day is a long day, and that all birds work early and late, the large number fed to one nest of young during their helpless period can easily be determined. This, of course, takes no account of the number of caterpillars eaten by the parents themselves to support them in their arduous labor.

The house wren, besides being a cheerful little creature about a house, is another very useful bird at killing insects. Its food consists almost entirely of insects. Some claim that it eats absolutely nothing else. It will build any place about dwellings where it can find lodgment for its nest. If undisturbed by cats, dogs, or human beings, the house wren will sit and sing within four or five feet of a person without showing any signs of fear.

It might be said here that cats are the worst enemies of birds. They no doubt drive away many valuable species that would otherwise be a source 
of pleasure and of profit. If shade trees, fruit trees, and other plants of the yard and garden are expected to thrive, they must be kept free from the ravages of noxious insects; and birds will do the work more cheaply and with less injury to the plants than anything else.

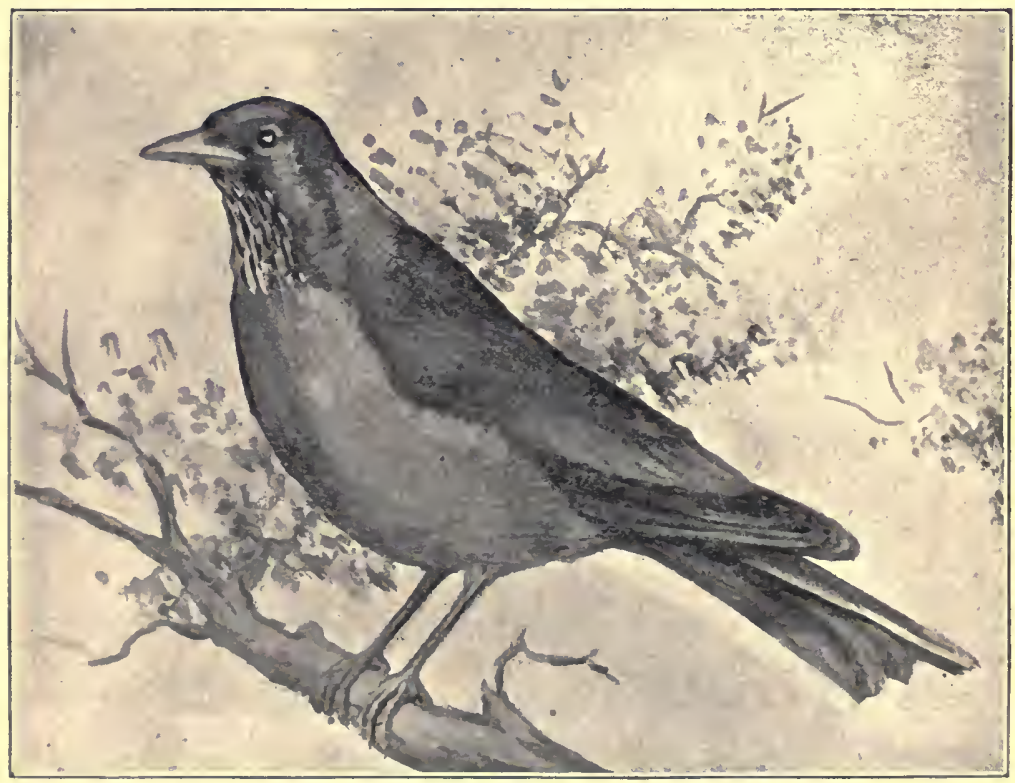

THE ROBIN.

Another beautiful bird is the robin. It eats some fruit, grain, and angleworms, for which it must be condemned, but it is so valuable in killing harmful insects that it more than pays for the damage. 
The robin is also a comparatively tame bird, feeding near dwellings as well as in open fields.

Bluebirds (see p. I44) are also very useful in killing caterpillars, grasshoppers, and many other injurious insects. During the grasshopper season the bluebird's food consists largely of this insect.

The bobolink (see p. 137) is a bird which deserves both praise and blame. In the northern part of the United States it lives almost entirely upon insects and weed seed; but, in the South, we are sorry to say, it does so much damage to rice fields that it is hunted and killed on every hand.

In concluding this short and incomplete discussion of useful birds, a few random notes from a late popular book on the subject will be given:-

"The goldfinch eats seeds of the thistle."

"The phoebe bird catches gnats and flies."

"Grouse catch spiders and beetles."

"English sparrows eat bark-insects from trees."

"Owls eat more mice and insects than birds."

"The woodpecker gets grubs and beetles from the trunks and branches of trees."

"The kingbird catches flies and beetles on the wing."

"Mr. Samuels says, "Thrushes rid the soil of noxious insects not preyed upon by other birds.'" "Some hawks eat insects." 


\section{CHAPTER VI.}

\section{BACTERIA.}

Their three general groups. Forms and growth. How bacteria may be destroyed. Their relation to the fertility of the soil. How decay produced by bacteria increases fertility in soils. Decay of fruits, meats, and vegetables. Various means of preserving food.

Relation of bacteria to dairy products. Part bacteria-play in making butter and cheese. Bacteria in vinegar-making.

In the air, on the surface of all objects, in water and in most all liquids, and in the soil everywhere, are millions of very small living things called bacteria, or germs. They are so small that, to see them, one requires the aid of a compound microscope. It takes several thousand bacteria, laid side by side or end to end, to make a line an inch long. Small as they are, they exist in such countless numbers that their influence in the world is very great.

In a very general way it can be said that there are three kinds of bacteria,- - those that are useful to man, those that are harmful, and those that are neither harmful nor useful. However, when they shall have been studied more, the last kind may be classed with one of the other two. Bacteria are generally thought of as producing disease. It is true that a number of species do produce disease; 
but these species are not so numerous as the harmless kinds.

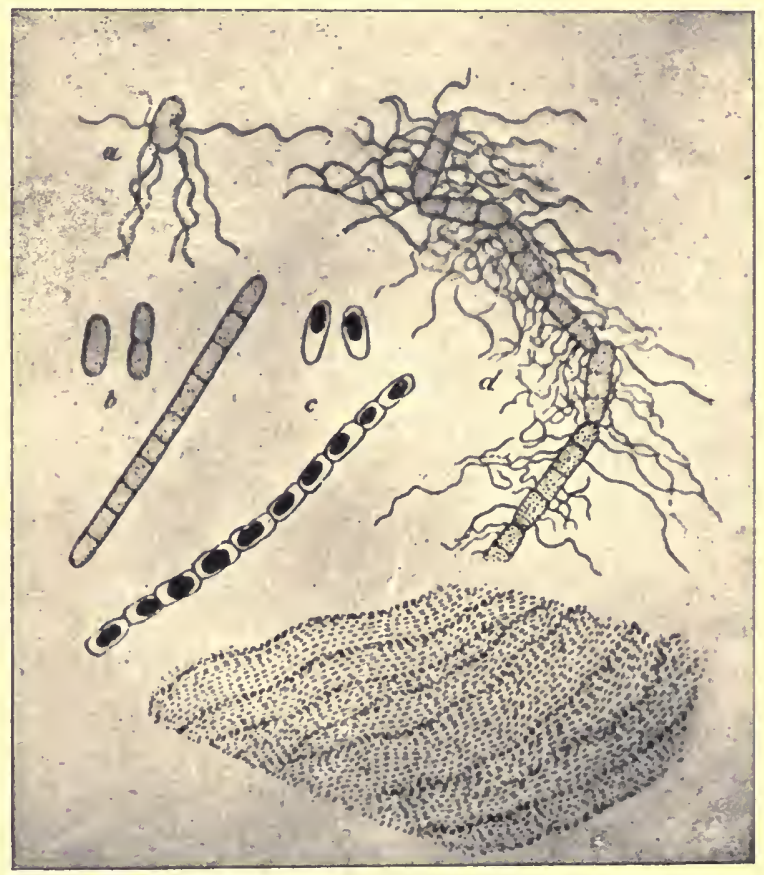

BACILLUS SUBTILIS IN HAY INFUSION.

$a$, short rod; $b$, non-motile rods and chains; $c$, spores; $d$, motile chains; $e$, mass of spores forming a pellicle.

\section{FORMS AND GROWTH.}

Though they are very small, yet bacteria have definite shapes. Some kinds are spherical, some cylindrical, and some spiral. These three general 
shapes represent all that have been discovered and studied up to the present time. The single bacterium consists of a single cell; and this single cell, simple as it is, carries on all the processes of life.

As with most one-celled plants and animals, bacteria multiply by division. The process is a simple one. The single cell divides into two parts, giving rise to two individuals instead of one. These two grow for a short time; then each one divides into two equal parts and four individuals are the result. These four in the same manner give rise to eight, and these eight to sixteen, and so on, the number always doubling. Some kinds divide at short intervals-not more than half an hour apart-but other kinds require a longer time.

Dividing once each half hour, one bacterium could thus give rise to several million individuals during a day of twenty-four hours, as can easily be computed. At this rapid rate of multiplication, they would soon fill the world if a sufficient food supply were at hand. The fact is that they soon exhaust their food supply in any one place and die of starvation, or are poisoned by the effect of too many living in one small colony.

Bacteria require moisture for their propagation and growth. They are distributed everywhere, but active life and growth are manifest only with the presence of moisture. Bacteria, as spores, are in and on all dry substances. Life in the spore state is dormant, just as life in some higher plants is 
dormant in seeds and bulbs. Bacteria can exist in this state for a long time, in many cases for years, and then become active when the necessary moisture is supplied.

In the spore or resistant state, bacteria are floating everywhere in large numbers in the dust of the atmosphere. Their minute size makes this possible. The more dust, of course, the more germs. The stirring up of dust on a street, in a house, or in a stable sets afloat millions of bacteria, to settle again after the air becomes quiet. In this manner they are carried from place to place and from object to object. They never rise and float away from a moist or liquid surface.

\section{HOW BACTERIA MAY BE DESTROYED.}

Not only moisture, but a certain amount of heat is necessary for the growth of bacteria. Too much heat kills them. Boiling from a few minutes to several hours destroys most kinds, but some are able to resist continued boiling in water and are killed only by a much greater heat. The best temperature for rapid growth is a little less than midway between freezing and boiling. Freezing stops the growth but does not destroy the life of bacteria. A substance in which they are growing may be frozen for a long time, stopping their growth for the period; but, on being thawed, their activity begins anew.

A great many chemical substances kill bacteria. 
The list is a very long one. They could be called, in general, poisons. They are sometimes termed germicides. A chemical that kills one species may not have any effect upon another. They are often killed by the excreta due to their own growth.

Bacteria require food just as other living things do. Their food must be in a moist, or liquid, condition. Wherever there is dead animal or vegetable matter in a moist state, with the temperature sufficiently warm, bacteria will begin to grow and multiply and cause decomposition. When the temperature is low, such as in ordinary freezing, winter weather, their action ceases; but it begins again when the temperature rises much above freezing.

Living, healthy plants and animals have the power to resist the attacks of bacteria. When life ceases, the resisting power ceases; so that a plant or animal begins to decay as soon as it is dead, especially in warm, moist weather. This decay is always due to the growth of bacteria.

RELATION OF BACTERIA TO THE FERTILITY OF THE SOIL.

It is a well-known fact among farmers that the fertility of the soil is soon exhausted by the successive raising and clearing off of crops, if nothing is given back in return. For long ages the earth has produced countless numbers of plants and animals which have derived their sustenance from the soil. All this time the soil has not only retained its 
strength, but has added thereto. Here is where these wonderful micro-organisms perform such an important part in the physical and chemical changes going on in the earth's crust.

As soon as plants and animals die, decomposition sets in-due to the action of bacteria. When their bodies fully decay, as much substance is returned to the earth as was taken from it by them. Another generation of plants and animals uses up this; but they, in turn, give back their bodies in decay to the soil. Thus, in nature's cycle of change, there is a using over and over again of the same substances; but the powerful action of bacteria makes it possible for the complete transformations to take place.

Even if the soil had been extremely fertile and deep in the beginning, the bodies of dead plants and animals would have accumulated to such an extent as to make further life impossible, had it not been for the presence of decomposing germs. Bodies of animals have been found preserved for ages in the ice of very cold regions. Decomposition did not take place because bacteria are dormant at such low temperatures.

It is similar with dried specimens. Decomposition germs cannot work without the presence of moisture. So bacteria keep the surface of the earth free from dead bodies of plants and animals by decomposing them and returniog them to the soil from whence they came. Bacteria are thus 
one of the prime factors in making continued life on the globe possible.

\section{HOW DECAY INCREASES FERTILITY.}

It must not be forgotten that bacteria cause decay of small creatures as well as of large ones, and that the fertility of the soil is due largely to the decay of many minute plants and animals. Untold millions of insects, and other small animals, among plants and in the ground, die annually. Their bodies are covered with decomposition germs, too, and they pass through the same stages of decay and change as the higher forms.

There are few better ways of increasing the fertility of a piece of land than to let it "rest"; that is, to cease cultivation and let it grow up in weeds. The increased fertility comes from the rapid decay of the great numbers of small plants and animals. For this reason it is always better to let a field grow up in weeds than to keep the surface clean. The weeds naturally afford forage and breeding places for insects and other small animals whose life is very short. They all die and are returned to the soil at the end of the season.

Bacteria live in the soil as well as on its surface. They help to decompose organic matter mixed with the soil. They are very numerous near the surface, and decrease downward. At a depth of five or six feet few, or none, are found.

Often organic matter in some soils will not 
decay. This is not due to the absence of bacteria, but to conditions which prohibit their growth. Some low, wet soils are of this nature. The soil water holds acids in solution. These kill germs. Such land generally becomes very productive when well drained, for the washing out of the acids gives the bacteria a chance to work. A good circulation of air in the soil also increases their action.

The decay of organic matter in general is caused by the action of germs. Waste matter from dwellings and stables readily decomposes when moisture is present. Such matter is generally piled in heaps to prevent loss of moisture by evaporation. Since decomposition produces heat, the rate of decay can be determined roughly by the temperature of the mass.

Farmers are careful to harvest their crops and store them away in a dry condition. Wet grain or hay will so decay or "turn sour" in a day or two, during very warm weather, as to become unfit for animal food. It can then be used only as a fertilizer. In some of these cases decay is due to the growth of moulds and fungi, but the result is the same as that produced by bacteria; namely, the reduction of the substances into several elements and compounds, their identity being destroyed.

DECAY OF FRUITS, VEGETABLES AND MEATS.

People have learned by experience that a wound caused by cutting or breaking the skin is attended 
with serious results, if care is not taken to exclude the air. The outside layer of skin, not being supplied with blood vessels, is germ proof, and excludes bacteria from the inner and more delicate parts. In a similar way, fruits and vegetables are covered with skin to keep out decomposition germs. When this skin is once broken germs enter, and decay quickly sets in.

Fruits and vegetables contain a large amount of water, and for this reason they are more subject to decay than grain, nuts, beans, and their like, that contain but a small amount of moisture. When the water is taken from them, they will keep for a long time, because germs cannot act without the presence of water. From this fact, the drying of fruits and vegetables has come about. Meats are dried for the same reason, and will keep for a long time in that condition.

The bacteria in vegetables, fruits, and meats can be killed by boiling for an hour or more. If the substances to be preserved are then put in cans which have been thoroughly cleaned and heated so as to kill all germs, and if the cans are hermetically sealed, they will keep their contents sound for an indefinite length of time. The things necessary to do in canning foods so that they will keep, are to kill all germs in the food and the inside of the cans; to seal while hot, so as not to allow other germs from the air to enter, and to keep sealed till the whole contents of a can are to be used. 
If living germs have been allowed to enter the can with the food, and decomposition or fermentation has set in, the fact may at once be known by the escape of confined gas. The principle of canning is founded upon the fact that the exclusion of bacteria from organic matter will prevent its decomposition.

VARIOUS MEANS OF PRESERVING FOOD.

Another method of controlling the action of germs in food is to reduce the temperature to near the freezing point. The low temperature simply keeps them from growing and multiplying. As soon as the temperature rises, they begin to act and the food spoils. For this reason meats, fruits, and vegetables keep longer during winter and in cold storage.

Bacteria cannot live in a strong solution of common salt (sodium chloride), and a great deal of meat, and some vegetables, are preserved through this means. The salt solution, however, produces some changes in such foods, so that they lose the flavor of their original freshness.

Some meats are "cured" with cominon salt, or other chemicals; some, by smoking. Fish and pork are thus treated. Smoking coats the outside of the meat with a thin layer of creosote (crude carbolic acid), which not only kills all germs present, but also gives the meat a better flavor. Carbolic acid is a dangerous substance to take into the 
human system in very large quantities, but there is so little of it on smoked meats that no harm whatever results. The smoke of most any kind of wnod will preserve meat, but some kinds give better flavors than others.

Sugar is also a preservative against the action of germs. It is used to a limited extent in curing meats, but very widely in the preservation of fruits. Such fruits are cooked for a long time. The cooking, or "boiling down," kills all germs present, and drives off the water, thus making conditions unfit for others to grow. Some dried fruits, such as figs, dates, raisins, and currants owe their good keeping qualities to the large a'nnunt of sugar present.

RELATION OF BACTERIA TO DAIRY PRODUCTS.

Milk, when freshly taken from the cow, contains few, or no, bacteria. During the ordinary process of milking, however, millions of germs find their way into the milk. Bacteria are floating in great numbers in the dust of barns. They are on the hay, in the litter on the floor, on the hairs of the cows and other animals, and in the clothing and on the hands of the milker himself.

Any hairs, dirt, or dust falling into the milk pail carry with them large numbers of germs. There is generally a great deal of dust in the cow stable at milking time. This is stirred up by the handling of hay and other feed. Cows shed their hair more or less all the time, and it is not uncommon for 
such hairs to drop into the pail during the process cf milking.

The milker often feeds the cows as well as milks them, consequently his hands are not absolutely free from dirt and dust. Some of the dirt finds its way into the milk pail. Most hairs, dirt, and other foreign bodies are removed from the milk when it is strained; but the germs clinging to them have become mixed with the liquid, and harmful results follow.

The milk pail itself is often a source of contamination. All milk vessels should be carefully washed and thoroughly scalded with boiling water. When this is not properly done, germs from the previous milking, and from other sources, are given to the fresh milk. Sunlight is a good disinfectant. All milk vessels, after being washed, should be sunned if clean, sweet, milk is desired

With the best of care to prevent contamination, some bacteria always find their way into milk freshly taken from the cow. It is difficult, if not absolutely impossible, to secure milk that has no bacteria in it.

It is a fact well known to dairymen that bacteria cause the souring of milk. A small number in the milk multiply into large numbers in a few hours. Here they find water and all essential foods for perfeut and rapid development, provided the liquid is kept warm enough. On a warm summer day the fresh product will sour in a few hours, if kept in 
the free, open air. A moderate degree of heat seems to be all that is needed.

From this fact has come the method of cooling milk to keep it sweet. Vessels containing fresh milk, if placed in the cold water of wells or springs, will attain a temperature low enough to keep it sweet for a day or two, according to the other influencing conditions. Ice, too, is used for cooling milk, and will keep it fresh for a longer time than ordinary cold water. Milk kept on ice, or in iced water, under favorable conditions, will stay sweet for several days.

The cooling process does not destroy the germs, but simply retards their action and holds it in check. The germs are still there, and will multiply and grow, causing the milk to sour, as soon as a sufficiently high temperature is restored.

When it is desired to destroy the life of bacteria in milk, boiling from a few minutes to an hour or more will accomplish the result. This is often done when harmful species, such as disease-producing germs, are present. If the milk is to be used immediately, no further care is necessary; but if it is to be kept for some time, it should be quickly cooled, and kept cool until needed. $\mathrm{B}_{\mathrm{y}}$ sealing in air-tight cans while hot, milk will keep sweet for a very long time; in fact, almost indefinitely, providing proper care is taken in sealing. The only objection to this method of killing the bacteria in milk is that the boiling produces a 
flavor objectionable to some people. However, it is the safest plan.

Certain chemicals added to milk will kill the bacteria present and keep the product fresh for a long time. Some of these are poisons, but so small a quantity is needed that harmful results need not follow. However, in the hands of ignorant or unskilled persons, the use of such chemicals is a dangerous experiment and should not be resorted to.

PART BACTERIA PLAY IN MAKING BUTTER AND CHEESE.

In butter-making, bacteria play a leading part. Fresh cream is sweet, but before it can be made into butter with a good flavor, it must undergo changes. These changes are called "ripening." Cream, when kept at the right temperature, sours, and the souring is necessary to give the product the right flavor. Several species of bacteria often work in the same cream, and the butter made from such cream is not of good quality. Each species produces its own peculiar flavor.

Butter-makers are very careful to exclude all kinds of bacteria except those that give the desired flavor and aroma. This is not always possible; but care and scientific methods have done a great deal to improve the quality of butter. Some buttermakers have almost absolute control over the species and growth of bacteria in their factories, 
so that they produce an article highly flavored and of a standard quality.

As soon as the butter is made, most of the bacteria die, probably on account of the small amount of water and the presence of a great deal of salt.

Some, however, remain alive. These, after a while, cause the butter to change its character and become rancid. Butter, to keep well, should have all of the water worked out, and a large amount of common salt mixed with it. Salt kills bacteria in butter just as it does in meat.

Cheese-making is also dependent upon the growth of bacteria. Cheese is made from the casein of milk. This is separated from the other products by rennet. After being separated, the casein is pressed into a solid mass of the shape and size desired, and then set away in a moderate temperature to ripen. It takes weeks, sometimes months, for cheese to ripen, depending upon the kind and the influencing conditions. The slowness of the process is probably due to the fact that a great deal of water is pressed from the mass in reducing it to a solid condition.

Often bacteria different from the ones desired get into cheese. 'These so change the product as to make it unfit for use. The cheese-maker cannot always control the germs in his cheese so as to produce grades of uniform quality and flavor; but, with care, most of the difficulties can be overcome. 
BACTERIA IN VINEGAR-MAKING.

Vinegar is a weak solution of acetic acid. On the farm it is usually made of apple cider. The juice of apples, and other juices of similar composition, contain more or less sugar. Sugar is readily converted into alcohol, and acetic acid is only oxidized alcohol. The organic compounds in cider are broken up and reunited through the action of bacteria.

Apple cider, in warm weather, after standing for about twenty-four hours, gives off bubbles of gas. The gas is carbon dioxide and the process is fermentation. The gas gives the cider a sparkling appearance and a spicy taste. After fermenting for another day or two, the cider acquires a strong, sour taste. In a few weeks of change, the product is vinegar.

The bacteria in the cider grow into a vast colony, forming a solid, slimy mass known as "mother of vinegar." They get into the cider first from the barrel itself, and from the air; but the process may be hastened by introducing some mother of vinegar. Sweet cider makes stronger and better vinegar than other kinds from the fact that it contains more sugar.

Vinegar is made in different ways and from different substances, but in most cases commercial vinegar is produced directly by the action of bacteria. 


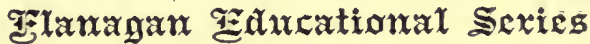

\section{United States History}

By JOHN W. GrBSON, author of Gibson's Chart History, etc. Cloth. 513 pages. Fully illustrated by maps, charts and diagrams. Introduction price, 80 cents. List price, $\$ 1.00$. Revised to date.

Prominent features of this popular text-book are:

1. The Topical Arrangement of the Matter.

2. A Large Use of Maps and Diagrams, many of them new and found only iu this work.

3. Historical Parallęl Readings, so placed as to be immediately useful to pupil and teacher.

4. A Combination with the Principles of Elementary Civics.

5. Summaries, Queries and References Correlating History,

Literature and Geography.

Very favorable terms for introduction and exchange.

\section{Civil Government}

\section{and

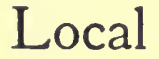 \\ History}

The attention of Superintendents, Teachers and Boards is invited to the fo!lowing successful volumes:

ILIINOIS AND THE NATION. By O. R. TROWBRIDGE. Cloth. 267 pages. Price, 60 cents. 50,000 copies sold.

THE MAKING OF ILLINOIS. By IRTIN W. MATHER, A. M. Cloth. 292 pages. Retail price, $\$ 1.00$. Pupil edition, 50 cents. Handsomely illustrated. Fine paper and clear type.

IOWA AND THE NATION. By Geo. ChandeEr. Supt. Schools, Osage, Iowa. Cloth. 35 t pages. Price, 90 cents. A popu!ar text.

THE MAKING OF IOWA. By HENRY SABIN, Es-State Supt. Iowa Schools. Cloth. Illuminated covers. Half-tone illus. tratlons. An attractive reading book. Retail price, $\div: 00$.

Many other valuable bocks, onthees etc., are described in our catalogue.

\section{A. FLANAGAN COMPANY, Publishers 266-268 Wabash Avenue,




\section{GREAT AMERICAN $\begin{array}{llllllllll}I & N & D & U & S & T & R & I & E & S\end{array}$}

Everywhere the movement is toward the practical. Manual Training is being rapidly introduced. In this connection, our Great American Industries have been before the public for some years. They are for student and teacher-are in demand everywhere. They are practical, sensible, complete-histories and descriptions of the subjects treated.

MINERALS is the first book. - In this volume is obtained an entertaining presentation of the practical side of mining and the business of handling mining products. Subjects treated: Copper and Zinc, Gold and Silver, Granite, Iron, Marble, Natural Gas, Petroleum, Slate, Coal.

PRODUCTS OF THE SOIL. On the same general plan as preceding volume. The history of the development of the industries is given a prominent place. It shows the practical side of the leading products of the soil-Indian Corn, Cotton, Lumber, Sugar, Wheat.

MANUFACTURING. In topics selected an effort has been made to chose those which are of general interest on account of their relation to our everyday life and the industrial development of the nation. The history, the method, the results; make an interesting and practical volume. Subjects treated: Motors, Glass, Leather, Boots and Shoes, Dressed Meats, Pins, Pencils and Pens, Paper, Printing, Newspapers, Books.

These books are now more generally in use than any others on the same or similar subjects. Are written in an entertaining style. Each volume from 178 to 225 pages.

Prices, each book, cloth, 50 cents; boards, 36 cents. 



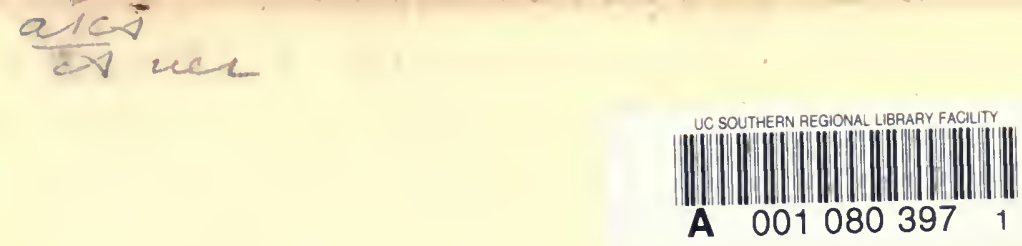

\section{STARE HORRALSCAOUL, LOS ANGELES, CEL.}




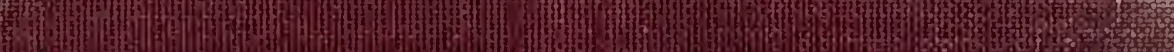

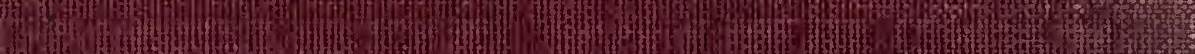

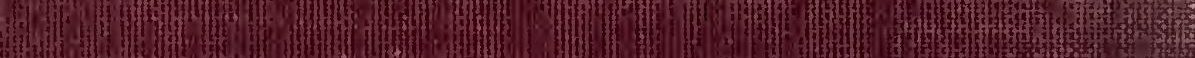
4. -14

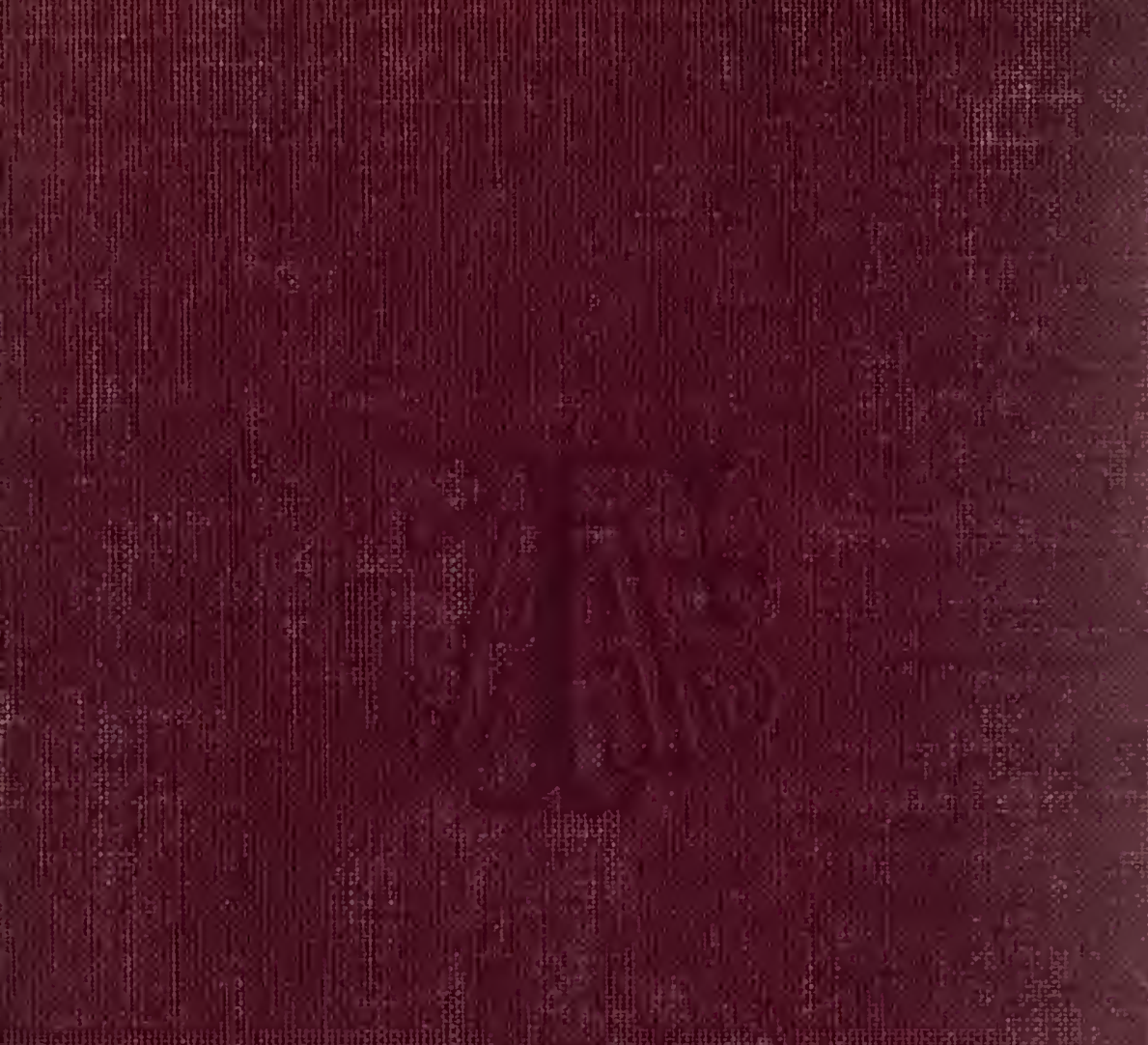

